\title{
The Gas-Phase Thermal Chemistry of Tetralin and Related Model Systems
}

\author{
by James Malandra
}

thesis submitted to Iowa State University

Ames Laboratory, U. S. DOE

Iowa State University

Ames, Iowa 50011

Date Transmitted: May 1993

\author{
Prepared for the U. S. Department of Energy \\ Under contract no. W-7405-eng-82.
}

\section{DISCLAIMER}

\begin{abstract}
This report was prepared as an account of work sponsored by an agency of the United States Therer United States Government nor any agency thereof, nor any of their employees, makes any warranty, express or implied, or assumes any legal liability or responsibility for the accuracy, completeness, or usefulness of any information, apparatus, product, or process disclosed, or represents that its use would not infringe privately owned rights. Reference herein to any specific commercial product, process, or service by trade name, trademark, ence herein to any specific commercial product, process, or sersily constitute or imply its endorsement, recommanufacturer, or otherwise does not States Government or any agency thereof. The views mendation, or favoring by the United States Government or any agency therest those of the United States Government or any agency thereof.
\end{abstract}


The gas-phase thermal chemistry of tetralin and related model systems

James L. Malandra

Under the Supervision of Walter S. Trahanovsky From the Department of Chemistry Iowa State University

In the gas-phase thermal decomposition of tetralin (1), the relative amounts of dehydrogenation products, 1,2-dihydronaphthalene (2) and naphthalene (5), to ethylene loss products, benzocyclobutene (3) and styrene (6), vary with the conditions of the experiment. The multiphoton dissociation (MPD) of 1 produces mostly ethylene loss while the pulsed and continuous wave (cw) laser-sensitized decomposition of 1 produces mostly dehydrogenation. The relative amounts of dehydrogenation to ethylene loss in the flash vacuum pyrolysis (FVP) of 1 are dependent on the system pressure and the sample temperature. When 1 is pyrolyzed under flow conditions, where sample molecules are diluted with a large excess of argon, ethylene loss exceeds dehydrogenation. We conclude that the lowest energy unimolecular gas-phase decomposition channel is ethylene loss. A bimolecular dehydrogenation reaction is responsible for greater amounts of hydrogen-loss products observed under some conditions. In none of our pyrolysis experiments did we find any evidence of heterogeneous catalytic reactions on surfaces.

We have observed the faclle transformation of o-allyltoluene (4) to 2-methylindan (7), which we propose occurs through an intramolecular hydrogen atom transfer from 
the benzylic methyl group to the double bond of 4 . Loss of a methyl from 7 leads to the formation of indene (8). We have identified the transformation 4 to 7 to 8 as the major source of 8 in the gas-phase thermal decomposition of 1 .

The FVP and photolysis of ketone 3-benzocycloheptenone and the FVP of sulfone 1,3,4,5-tetrahydro-2-benzothiepin-2,2-dioxide were studied to produce the 1,6-diradical formed by cleavage of the benzylic bond of 1 . An unusual aspect of the ketone pyrolysis is the formation of 1-methylnaphthalene and 2-methylnaphthalene, products formed by a net loss of water from 3-benzocycloheptenone. Bis(o-allylbenzyl) oxalate was pyrolyzed to observe the gas-phase thermal chemistry of 0 -allylbenzyl radical. The FVP of 1,4-diphenylbutane produces 3-phenylpropyl radical. The FVP of o-(3-butenyl)toluene and o-(4-pentenyl)toluene were also studied. 
The gas-phase thermal chemistry of tetralin and related model systems

by

James Louis Malandra

A Dissertation Submitted to the

Graduate Faculty in Partial Fulfillment of the

Requirements for the Degree of

DOCTOR OF PHILOSOPHY

Department: Chemistry

Major: Organic Chemistry

Approved:

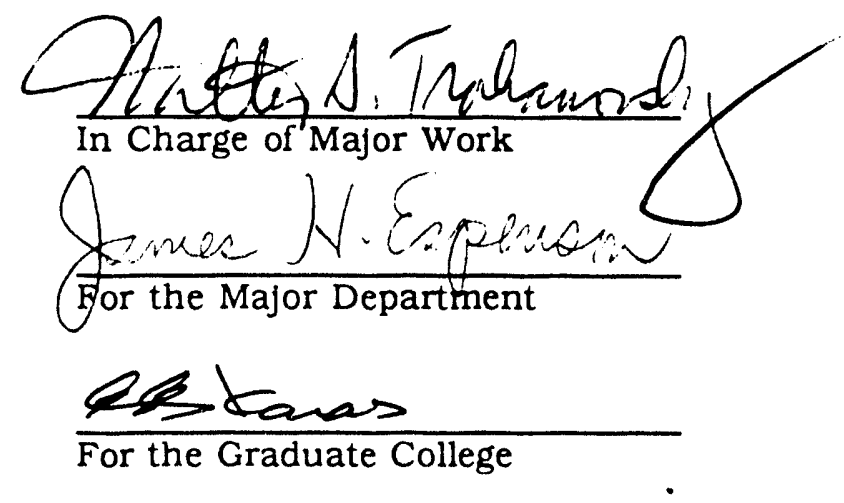

Iowa State University

Ames, lowa

1993 
TABLE OF CONTENTS

Page

GENERAL INTRODUCTION

Explanation of Dissertation Format 2

PAPER 1. THE GAS-PHASE THERMAL DECOMPOSITION OF TETRALIN

3

INTRODUCTION

$\begin{array}{ll}\text { RESULTS } & 6\end{array}$

Primary Pathways in Tetralin Decomposition $\quad 6$

$\begin{array}{ll}\text { Laser-induced decomposition } & 6\end{array}$

$\begin{array}{ll}\text { Flash vacuum and flow pyrolysis } & 13\end{array}$

Secondary Pathways in Tetralin Decomposition 16

DISCUSSION $\quad 22$

Dehydrogenation vs. Ethylene Loss in Tetralin Decomposition 22

Laser-induced decomposition $\quad 22$

$\begin{array}{ll}\text { Flash vacuum and flow pyrolysis } & 26\end{array}$

Primary Pathways in Tetralin Decomposition 28

Secondary Pathways in Tetralin Decomposition $\quad 35$

$\begin{array}{ll}\text { CONCLUSION } & 37\end{array}$

$\begin{array}{ll}\text { EXPERIMENTAL SECTION } & 38\end{array}$

$\begin{array}{ll}\text { General Procedures } & 38\end{array}$

$\begin{array}{ll}\text { Apparatus } & 38\end{array}$ 
Laser-Induced pyrolysis

$\begin{array}{ll}\text { Flash vacuum pyrolysis } & 40\end{array}$

Flow pyrolysis $\quad 40$

Methods and materials 41

Benzocyclobutene (3) 42

$\begin{array}{ll}\text { o-Allyltoluene (4) } & 42\end{array}$

2-Methyl-1H-indene 43

2-Methylindan (7) 43

3-Methyl-1H-indene 43

1-Methylindan 43

Laser-induced pyrolysis $\quad 44$

Flash vacuum pyrolysis $\quad 45$

Flow pyrolysis $\quad 45$

$\begin{array}{ll}\text { Product analysis } & 46\end{array}$

$\begin{array}{ll}\text { REFERENCES } & 48\end{array}$

APPENDIX 1 SUPPLEMENTARY DATA TABLES

APPENDIX 2 SUPPLEMENTARY PROCEDURES AND CALCULATIONS 62

$\begin{array}{ll}\text { Detailed procedure for flow pyrolysis } & 62\end{array}$

Calculation of residence time for flow pyrolysis $\quad 63$

APPENDIX 3 ADDITIONAL DATA ON THE PYROLYSIS OF TETRALIN 66

$\begin{array}{ll}\text { Flow rate in flow pyrolysis } & 66\end{array}$

$\begin{array}{ll}\text { Carrier gas in flow pyrolysis } & 68\end{array}$

$\begin{array}{ll}\text { Pyrolysis tube size in flow pyrolysis } & 71\end{array}$

$\begin{array}{ll}\text { Copyrolysis with diluents in FVP } & 71\end{array}$ 
PAPER 2. THE FLASH VACUUM PYROLYSIS OF 3-BENZOCYCLOHEPTENONE AND 1,3,4,5-TETRAHYDRO-2-BENZOTHIEPIN-2,2-DIOXIDE: MODEL SYSTEMS FOR THE

$\begin{array}{ll}\text { INTRODUCTION } & 76\end{array}$

$\begin{array}{ll}\text { RESULTS } & 78\end{array}$

$\begin{array}{lc}\text { DISCUSSION } & 84\end{array}$

$\begin{array}{ll}\text { CONCLUSION } & 89\end{array}$

$\begin{array}{ll}\text { EXPERIMENTAL } & 90\end{array}$

$\begin{array}{ll}\text { General Procedures } & 90\end{array}$

$\begin{array}{ll}\text { Methods and materials } & 90\end{array}$

3-Benzocycloheptenone (10) 90

1,3,4,5-Tetrahydro-2-benzothiepin-2,2-dioxide (11) 92

$\begin{array}{ll}\text { Flash vacuum pyrolysis } & 94\end{array}$

Flow pyrolysis $\quad 94$

Photolysis $\quad 94$

$\begin{array}{ll}\text { Product analysis } & 95\end{array}$

$\begin{array}{ll}\text { REFERENCES } & 96\end{array}$

APPENDIX 1 SUPPLEMENTARY DATA TABLES 99

APPENDIX 2 SUPPLEMENTARY PROCEDURES AND CALCULATIONS 107

$\begin{array}{ll}\text { Detailed procedure for flow pyrolysis of ketone (10) } & 107\end{array}$

Calculation of residence time for flow pyrolysis of ketone (10) 108 
PAPER 3. THE HIGH-TEMPERATURE GAS-PHASE REACTIONS OF O-ALLYLBENZYL RADICALS GENERATED BY FLASH VACUUM PYROLYSIS OF BIS(o-ALLYLBENZYL) OXALATE 109

$\begin{array}{lr}\text { INTRODUCTION } & 110 \\ \text { RESULTS } & 112 \\ \text { DISCUSSION } & 114 \\ \text { CONCLUSION } & 116 \\ \text { EXPERIMENTAL } & 117 \\ \text { General Procedures } & 117 \\ \qquad \text { Methods and materials } & 117 \\ \quad \text { Bis(o-allylbenzyl) oxalate (9) } & 117 \\ \quad \text { Flash vacuum pyrolysis } & 119 \\ \text { Product analysis } & 119 \\ \text { REFERENCES } & \text { SUPPLEMENTARY DATA TABLE }\end{array}$

APPENDIX SUPPLEMENTARY DATA TABLE 122

PAPER 4. THE FLASH VACUUM PYROLYSIS OF 1,4-DIPHENYLBUTANE 
$\begin{array}{lll}\text { EXPERIMENTAL } & 133\end{array}$

$\begin{array}{ll}\text { General Procedures } & 133\end{array}$

$\begin{array}{ll}\text { Methods and materials } & 133\end{array}$

1.4-Diphenylbutane (9) 133

Flash vacuum pyrolysis $\quad 133$

$\begin{array}{ll}\text { Product analysis } & 133\end{array}$

$\begin{array}{ll}\text { REFERENCES } & 134\end{array}$

APPENDIX SUPPLEMENTARY DATA TABLE $\quad 135$

PAPER 5. THE FLASH VACUUM PYROLYSIS OF O-ALLYLTOLUENE, o-(3-BUTENYL)TOLUENE AND O-(4-PENTENYL)TOLUENE 137

$\begin{array}{ll}\text { INTRODUCTION } & 138\end{array}$

$\begin{array}{ll}\text { RESULTS } & 140\end{array}$

$\begin{array}{ll}\text { DISCUSSION } & 144\end{array}$

$\begin{array}{ll}\text { CONCLUSION } & 148\end{array}$

$\begin{array}{ll}\text { EXPERIMENTAL } & 149\end{array}$

$\begin{array}{ll}\text { General Procedures } & 149\end{array}$

$\begin{array}{ll}\text { Methods and materials } & 149\end{array}$

o-Allyltoluene (4) $\quad 149$

$\begin{array}{ll}\text { o-(3-Butenyl)toluene (9) } & 149\end{array}$

o-(4-Pentenyl)toluene (10) 150

Flash vacuum pyrolysis $\quad 150$

$\begin{array}{ll}\text { Product analysis } & 150\end{array}$ 
REFERENCES

APPENDIX SUPPLEMENTARY DATA TABLES

153

GENERAL SUMMARY

161

ACKNOWLEDGMENTS

165 


\section{LIST OF FIGURES}

PAPER 1

Figure 1. The dehydrogenation to ethylene loss ratio vs. conversion at two system pressures

Figure 2. Schematic diagram of flow pyrolysis apparatus

Figure 3. Schematic diagram of the experimental arrangement for the sensitized pulsed laser-induced pyrolysis

PAPER 5

Figure 1. Plot of temperature vs. conversion for the FVP of $o$-allyltoluene (4), o-(3-butenyl)toluene (9), and o-(4-pentenyl)toluene (10) 146 
ix

\section{LIST OF TABLES}

Page

PAPER 1

Table I. Products and dehydrogenation to ethylene loss ratio from MPD of tetralin (1)

Table II. Products and dehydrogenation to ethylene loss ratio from sens1tized pulsed laser-induced decomposition of tetralln (1)

Table III. Products and dehydrogenation to ethylene loss ratio from sensitized cw laser-induced decomposition of tetralin (1)

Table IV. Products and dehydrogenation to ethylene loss ratio from sensitized cw laser-induced decomposition of tetralin (1) in the presence of hydrogen atom chain terminators

Table V. Total recovery of material, conversion, and dehydrogenation to ethylene loss ratio from FVP of tetralin (1) at $10^{-5}$ torr and various oven temperatures

Table VI. Total recovery of material, conversion, and dehydrogenation to ethylene loss ratio from FVP of tetralin (1) at 0.10 torr and various oven temperatures

Table VII. Total recovery of material, conversion, and dehydrogenation to ethylene loss ratio from FVP of tetralin (1) at $10^{-5}$ torr and vartous sanıple temperatures

Table VIII. Products and recovered starting material and dehydrogenation to ethylene loss ratio from flow pyrolysis of tetralin (1) at various oven temperatures 
Table IX. Products and recovered starting material from flow pyrolysis of o-allyltoluene (4) at various oven temperatures

Table X. Products and recovered starting material from flow pyrolysis of 1,2-dihydronaphthalene (2) at various oven temperatures

Table A-I. Products and recovered starting material, total recovery of materia, and conversion from the FVP of tetralin (1) at $10^{-5}$ torr and various oven temperatures

Table A-II. Products and recovered starting material, total recovery of material, and conversion from the FVP of tetralin (1) at 0.10 torr and various oven temperatures

Table A-III. Products and recovered starting material, total recovery of materfal, and conversion from the FVP of tetralin (1) at $10^{-5}$ torr and various sample temperatures

Table A-IV. Products and recovered starting material, total recovery of material, and conversion from the flow pyrolysis of tetralin (1) at various oven temperatures

Table A-V. Products and recovered starting material, total recovery of material, and conversion from the flow pyrolysis of o-allyltoluene (4) at various oven temperatures

Table A-VI. Products and recovered starting material, total recovery of material, and conversion from the flow pyrolysis of 1.2-dihydronaphthalene (2) at various oven temperatures 
Table A3-I. Products and recovered starting material, total recovery of material, conversion, and dehydrogenation to ethylene loss ratio from the flow pyrolysis of tetralin (1) at various flow rates

Table A3-II. Products and recovered starting material, total recovery of material, conversion, and dehydrogenation to ethylene loss ratio from the flow pyrolysis of tetralin (1) with helium carrier gas

Table A3-III. Products and recovered starting material, total recovery of material, conversion, and dehydrogenation to ethylene loss ratio from the flow pyrolysis of tetralin (1) with hydrogen in argon carrier gas

Table A3-IV. Products and recovered starting material, total recovery of material, conversion, and dehydrogenation to ethylene loss ratio from the flow pyrolysis of tetralin (1) with $3 \mathrm{~mm}$ (id) pyrolysis tube

PAPER 2

Table I. Products and recovered starting materlal from FVP of 3-benzocycloheptenone (10) at various oven temperatures

Table II. Products and recovered starting material from flow pyrolysis of 3-benzocycloheptenone $(10)$ at various oven temperatures

Table III. Products and recovered starting material from photolysis of 3-benzocycloheptenone (10)

Table IV. Products and recovered starting material from FVP of 1,3,4,5-tetrahydro-2-benzothlepin-2,2-dioxide (11) at various oven temperatures 
Table A-I. Products and recovered starting material, total recovery of material, and conversion from the FVP of 3-benzocycloheptenone (10) at various oven temperatures

Table A-II. Products and recovered starting material, total recovery of material, and conversion from the flow pyrolysis of 3-benzocycloheptenone (10) at various oven temperatures

Table A-III. Products and recovered starting material, total recovery of material, and conversion from the photolysis of 3-benzocycloheptenone (10)

Table A-IV. Products and recovered starting material, total recovery of material, and conversion from the FVP of 1,3,4,5-tetrahydro-2-benzothiepin-2,2-dioxide (11) at various oven temperatures

\section{PAPER 3}

Table I. Products and recovered starting material from FVP of bis(o-allylbenzyl) oxalate (9) at various oven temperatures

Table A-I. Products and recovered starting material, total recovery of material, and conversion from the FVP of bis(o-allylbenzyl) axalate (9) at various oven temperatures

\section{PAPER 4}

Table I. Products and recovered starting material from the FVP of 1,4-diphenylbutane (9) at various oven temperatures 
Table A-I. Products and recovered starting material, total recovery of material, and conversion from the FVP of 1,4-diphenylbutane (9) at various oven temperatures

\section{PAPER 6}

Table I. Products and recovered starting material from the FVP of 0 -allyltoluene (4) at various oven temperatures

Table II. Products and recovered starting material from the FVP of $o$-(3-butenyl)toluene (9) at various oven temperatures

Table III. Products and recovered starting material from the FVP of o-(4-pentenyl)toluene $(\mathbf{1 0})$ at various oven temperatures

Table IV. Linear least squares line for temperature vs. conversion and $\Delta \mathrm{H}^{\ddagger}$ for the FVP of o-allyltoluene (4), o-(3-butenyl)toluene (9), and o-(4-pentenyl)toluene (10)

Table A-I. Products and recovered starting material, total recovery of material, and conversion from the FVP of $o$-allyltoluene (4) at various oven temperatures

Table A-II. Products and recovered starting material, total recovery of material, and conversion from the FVP of 0 -(3-butenyl)toluene (9) at various oven temperatures

Table A-III. Products and recovered starting material, total recovery of material, and conversion from the FVP of o-(4-pentenyl)toluene (10) at various oven temperatures 


\section{GENERAL INTRODUCTION}

For the past decade, workers in the Trahanovsky research group have been studying the gas-phase thermal decomposition of simple organic molecules as model systems of various features of coal structure. The hydrocarbon tetralin, the simplest hydroaromatic compound, has been studied as a model of this important structural feature of coal. Previous siudies on the decomposition of tetralin have shown that tetralin decomposes to produce the dehydrogenation products 1,2-dihydronaphthalene and naphthalene, the ethylene-loss products benzocyclobutene and styrene, and other products such as indene and o-allyltoluene in smaller amounts. Pyrolysis studies in the literature using conventional heating techniques produced primarlly dehydrogenation products, while in laser-induced decomposition and shock tube experiments ethylene loss predominated. It has been suggested that catalytic dehydrogenation is occurring using the conventional pyrolysis techniques. Our purpose has been to clarify these discrepancies and to determine to what extent, if any, heterogeneous surface catialysis is involved in the decomposition of tetralin. Additionally, we have been interested in the mechanism of tetralin decomposition and have designed several model compounds to probe the viability of varlous mechanistic pathways. The five papers in this dissertation describe our studies of tetralin decomposition and related model systems using the techniques of laser-induced decomposition, flash vacuum pyrolysis (FVP), and flow pyrolysis.

In paper 1, studies of the gas-phase thermal decomposition of tetralin itself are presented. This paper is part of a collaborative project with Professor Edward S. Yeung and the experimental work involving laser-induced decomposition is part of the Ph.D. dissertation of Jianzhong Zhu (Iowa State University, 1989). Paper 2 contains the 
2

results of the decomposition of two systems related to tetralin, ketone 3-benzocycloheptenone and sulfone 1,3,4,5-tetrahydro-2-benzothiepin-2,2-dioxide. In papers 3 and 4 , the FVP of bis(o-allylbenzyl) oxalate and 1,4-diphenylbutane, respectively, are described. Paper 5 concerns the FVP of o-allyltoluene, a primary product in tetralin decomposition.

\section{Explanation of Dissertation Format}

This dissertation consists of five complete papers in the style suitable for publication in Journals published by the American Chemical Society. As such, each section has its own numbering system and reference section following the text. Detalled analytical data are contained in an appendix following each section. The research described in the results and experimental sections was done by the author unless otherwise indicated. Paper 1 is the result of a collaborative project as described above. The material in paper 1 that is part of the Ph.D. dissertation of Jianzhong Zhu (Iowa State University, 1989) is indicated with a footnote. A general summary follows the final paper. 
PAPER 1. THE GAS-PHASE THERMAL DECOMPOSITION

OF TETRALIN 


\section{INTRODUCTION}

Our recent research efforts have been directed toward understanding the gas-phase thermal chemistry of tetralin (1). In previous work, 1 has been used as a hydrogen-donor solvent for coal liquefaction processes ${ }^{1}$ and, as the simplest hydroaromatic compound, has been studied as a model of this important structural feature of coal. ${ }^{2}$ The gas-phase chemistry of 1 at elevated temperatures has been examined under static, flow, and vacuum pyrolysis conditions, 3,4 through sensitized laser-induced thermal decomposition, 5,6 and in single-pulse shock tube experiments. ${ }^{7}$ The major products of tetralin thermal decomposition (Scheme I) include primary products 1.2-dihydronaphthalene (2), benzocyclobutene (3), and o-allyltoluene (4). Secondary products, naphthalene (5) from 2, styrene (6) from 3, 2-methylindan $(7)^{8}$ from 4 , and indene (8) primarily from 7, have been identified along with various minor products.

Analysis of the complex tetralin product mixtures is simplified by treating the "hydrogen-loss" or dehydrogenation products 1,2-dihydronaphthalene (2) and naphtha-

\section{Scheme I}

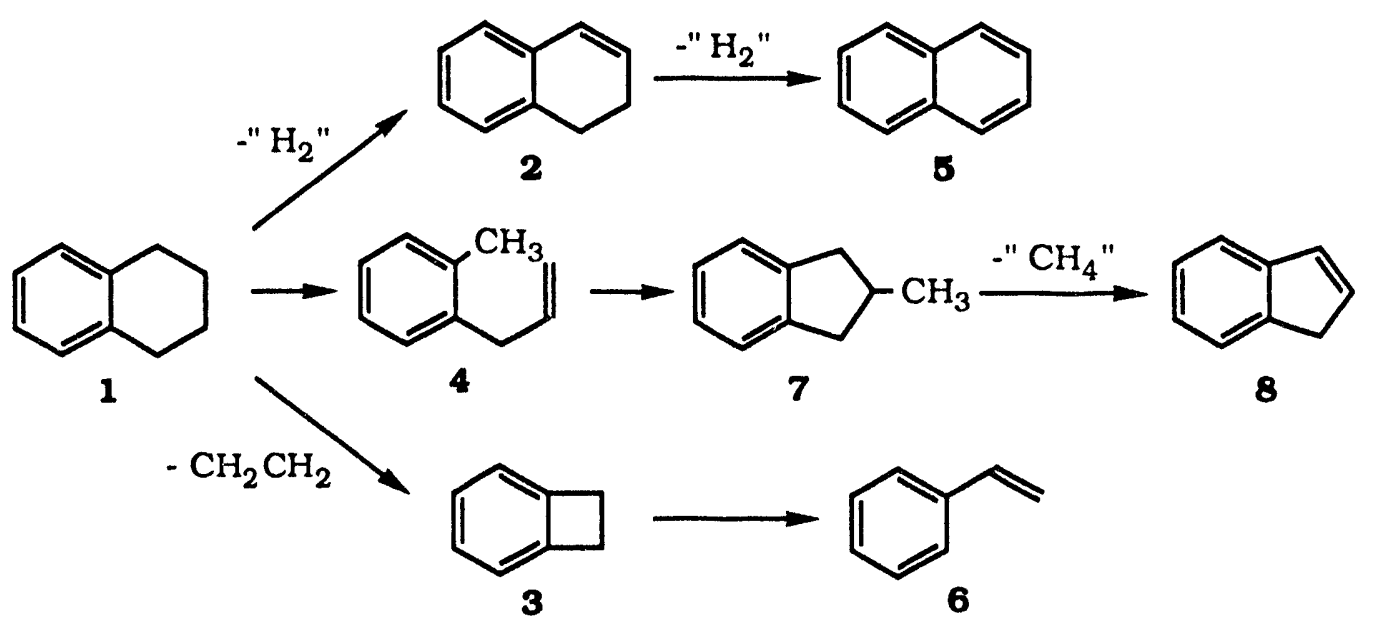


lene (5) together. Simllarly, benzocyclobutene (3) and styrene (6) are also considered as a group and referred to as "ethylene-loss" products. The ratio of dehydrogenation to ethylene loss will be used to evaluate tetralın pyrolysis mixtures.

Gas-phase pyrolysis ${ }^{4}$ of 1 has been reported to give primarily dehydrogenation. while laser-induced decomposition ${ }^{5}$ and single-pulse shock tube studies ${ }^{7}$ gave primarily ethylene loss. It has been suggested that surface catalytic effects have influenced the pyrolysis results. $5 \mathrm{~b}$ In this paper, we report our reexamination of the thermal decomposition of : under both laser-induced and pyrolysis conditions.

In our experiments, the laser-sensitized decomposition of 1 produced primarily dehydrogenation. These results are at variance with those previously reported; 5 however, our gas-phase pyrolysis results confirm that the lowest energy unimolecular decomposition reaction of 1 is ethylene loss. We show that the excess dehydrogenation observed is not the result of a surface catalytic effect. We belleve a bimolecular reaction sequence produces excess dehydrogenation under some conditions. 


\section{RESULTS}

\section{Primary Pathways in Tetralin Decomposition}

\section{Laser-Induced decomposition 6}

We have studied the laser-induced decomposition of tetralin (1) under reaction conditions and analytical procedures that were chosen to match closely those reported earlier. 5 Three types of laser-induced decomposition experiments were performed: direct multiphoton dissociation (MPD), 10 sensitized thermal decomposition by pulsed IR laser, ${ }^{11}$ sensitized thermal decomposition by continuous wave (cw) IR laser.

In the MPD of 1 (Table I), ethylene loss to form benzocyclobutene (3) and styrene (6) is clearly the major reaction pathway. This result is in agreement with the previous study. 5

The laser-induced sensitized pyrolysis of 1 has also been examined. In our experiments, no part of the cell felt warm to the touch even at the highest laser powers used

Table I. Products and dehydrogenation to ethylene loss ratio from MPD of tetralin (1) $a, b$

\begin{tabular}{|c|c|c|c|c|c|c|c|c|}
\hline \multirow[b]{2}{*}{ pulses } & \multirow[b]{2}{*}{$\begin{array}{c}\text { conversion, } \\
\% d\end{array}$} & \multirow[b]{2}{*}{$\begin{array}{l}\text { ratio } \\
\frac{(2+5)}{(3+6)} \\
\end{array}$} & \multicolumn{6}{|c|}{ yleld, $\%_{0} c$} \\
\hline & & & 2 & 5 & 3 & 6 & 4 & $\begin{array}{l}\text { other } \\
\text { prods. }\end{array}$ \\
\hline 950 & 1.3 & 0.45 & 25.1 & 4.4 & 54.1 & 11.0 & - & 5.4 \\
\hline 2812 & 2.3 & 0.61 & 26.0 & 8.9 & 48.2 & 9.0 & 7.5 & 0.4 \\
\hline
\end{tabular}


so that reactions on hot surfaces can be neglected. No decomposition products were found when the reaction mixture was left in the cell for 28 hours without laser irradiation.

A representative selection of the results of the pulsed laser sensitized decomposition of 1 is shown in Table II. The pulse energies for $\mathrm{SF}_{6}$ and $\mathrm{StF}_{4}$ sensitization cannot be compared directly, since the absorption coefficients of the sensitizers are quite different. Regardless of the sensitizer, at low excitation energies and low conversions, dehydrogenation is the dominant reaction. At higher pulse energies, the ratio of dehydrogenation to ethylene loss is ca. 1. This is in contrast to earlier reports, 5 where ethylene loss was found to be the major dissociation channel. No fluorinated hydrocarbons were found in the GCMS analysis indicating the sensitizer acts only as a heat-transfer agent.

The results of $\mathrm{cw}$ laser-induced thermal decomposition is shown in Table III. Invariably, the major products are associated with dehydrogenation. Longer reaction times are required with $\mathrm{SiF}_{4}$ to achieve similar conversions because of the difference in absorption coefficients for $\mathrm{SiF}_{4}$ and $\mathrm{SF}_{6}$. As expected, substantial conversion to secondary products (5 and $\mathbf{8}$ ) occurs when the reaction yields are high. The two studies involving $\mathrm{SF}_{6}$ show that energy density, and not just total energy deposited, is important to the extent of reaction and the "maximum temperature", as was pointed out in the previous work. $5 \mathrm{~b}$ No fluorinated hydrocarbons were found in the GCMS analysis indicating the sensitizer acts only as a heat-transfer agent in tetralin decomposition.

To assess the contributions of surface reactions to the overall decomposition process, we studied the dependence of the absolute ylelds of products on the size and shape of the sample cell at a fixed input laser power of $9 \mathrm{~W}$. Under these conditions, the major 
Table II. Products and dehydrogenation to ethylene loss ratio from sensitized pulsed laser-induced decomposition of tetralin (1) $a$

\begin{tabular}{|c|c|c|c|c|c|c|c|c|c|c|c|}
\hline \multirow[b]{2}{*}{$\begin{array}{l}\text { laser energy, } \\
\mathrm{J}_{\text {pulse }}{ }^{-1}\end{array}$} & \multirow[b]{2}{*}{ pulses } & \multirow[b]{2}{*}{$\begin{array}{c}\text { sensittzer } \\
\text { (P, torr) }\end{array}$} & \multirow[b]{2}{*}{$\begin{array}{c}\text { conversion, } \\
\% \mathrm{c}\end{array}$} & \multirow[b]{2}{*}{$\begin{array}{l}\text { ratio } \\
(2+5) \\
(3+6)\end{array}$} & \multicolumn{7}{|c|}{ yield, $\% b$} \\
\hline & & & & & 2 & 5 & 3 & 6 & 4 & 8 & $\begin{array}{l}\text { other } \\
\text { prods. }\end{array}$ \\
\hline 0.04 & 3420 & $\mathrm{SF}_{6}(3)^{d}$ & 0.1 & $>30$ & 75.8 & 24.2 & - & - & - & - & - \\
\hline 0.26 & 5 & $\mathrm{SF}_{6}(3) d$ & 0.7 & 1.0 & 19.1 & 22.7 & 14.9 & 24.5 & 12.4 & 1.6 & 4.8 \\
\hline 0.09 & 2000 & $\mathrm{SiF}_{4}(6) e$ & 0.4 & $>20$ & 63.4 & 36.5 & trace & trace & - & - & 0.1 \\
\hline 0.11 & 2500 & $\mathrm{SiF}_{4}(6) e$ & 3.8 & 0.99 & 49.7 & trace & 50.3 & - & - & - & - \\
\hline
\end{tabular}

$a$ See Table I, footnote $b^{b}$ See Table I, footnote $c{ }^{c}$ See Table I, footnote $d{ }^{d}$ Laser-induced pyrolysis conditions: cell

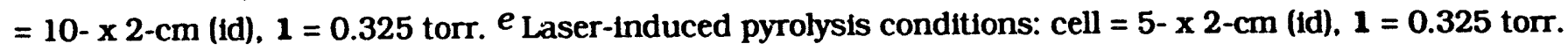


Table II. Products and dehydrogenation to ethylene loss ratio from sensitized $\mathrm{cw}$ laser-induced decomposition of tetralin (1) $a, b$

\begin{tabular}{|c|c|c|c|c|c|c|c|c|c|c|c|}
\hline \multirow[b]{2}{*}{$\begin{array}{c}\text { laser } \\
\text { power, w }\end{array}$} & \multirow[b]{2}{*}{ time } & \multirow[b]{2}{*}{$\begin{array}{c}\text { sensitizer } \\
\text { (P. torr) }\end{array}$} & \multirow[b]{2}{*}{$\begin{array}{c}\text { conversion, } \\
\%^{d}\end{array}$} & \multirow[b]{2}{*}{$\begin{array}{l}\text { ratio } \\
\frac{(2+5)}{(3+6)}\end{array}$} & \multicolumn{7}{|c|}{ yield, $\% c$} \\
\hline & & & & & 2 & 5 & 3 & 6 & 4 & 8 & $\begin{array}{l}\text { other } \\
\text { prods. }\end{array}$ \\
\hline 5.0 & $12 \mathrm{~h}$ & $\mathrm{SiF}_{4}(6)$ & 2.1 & $>20$ & 100 & trace & trace & - & - & - & - \\
\hline 6.6 & $5 \mathrm{~min}$ & $\mathrm{SF}_{6}(3)$ & 1.1 & 5.8 & 70.6 & 14.6 & 14.7 & - & - & - & 0.1 \\
\hline 14.5 & $1 \mathrm{~min}$ & $\mathrm{SF}_{6}(3)$ & 58.2 & 1.7 & 3.1 & 55.5 & 1.8 & 31.9 & 7.6 & 0.5 & - \\
\hline
\end{tabular}

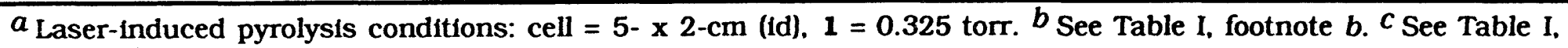
footnote $c$. $d$ See Table I, footnote $d$. 
reaction products are 2 and $\mathbf{5}$. For tylindrical cells of length $(\mathrm{cm}) \mathbf{x}$ internal diameter $(\mathrm{cm})$ of $4 \times 3.8,4 \times 2.8,2 \times 2.8$, and $1 \times 2.8$, the measured formation rates $\left(10^{-12} \mathrm{~mol} \mathrm{~s}^{-1}\right)$ for 2 plus 5 are $121,52,1.9$, and 0.21 , respectively.

Deuterlum labeling studies were done to provide additional insight into the mechanism of cw laser sensitized dehydrogenation. In these experiments, the total conversion was kept low to avold secondary pyrolysis products. Dehydrogenation of 1 was the main reaction observed. Two types of studies were performed. In the first series of experiments, the deuterium distribution in 2 was determined for the pyrolysis of 1,1,4,4-d4-tetralin. The relative amounts of $d_{0}, d_{1}, d_{2}, d_{3}$, and $d_{4}$ in 2 were found to be $2.0 \%, 0.8 \%, 10.9 \%, 80.2 \%$, and $6.2 \%$, respectively. These distributions are comparable to those obtalned in the pulsed laser sensitized pyrolysis of 1,1,4,4-d4-tetralin. 5

In a second set of experiments, the deuterium distribution in the hydrogen gas formed during the pyrolysis of $1: 1$ mixtures of 1 and $d_{12-1}$ were measured. The relative amounts of $\mathrm{H}_{2}, \mathrm{HD}$, and $\mathrm{D}_{2}$ were found to be 53:35:12 at laser power $8.6 \mathrm{~W}$ with a $3 \mathrm{~min}$ irradiation time. These results are also consistent with those reported earlier. 5

To assess the importance of hydrogen atom chain reactions, we studied the effect of potential chain terminators on the cw pyrolysis of 1 . Table IV shows sets of experiments involving the addition of potential chain terminators. Ideally, the species added should be in large excess; however, the maximum temperature may vary due to a change in the effective thermal conductivity of the gas. 12 Conversion was maintained low enough to avoid secondary pyrolysis reactions yet sufficiently high to allow reliable analysis of the products.

Table IV shows that the addition of toluene as a potential chain terminator ${ }^{13}$ to the pyrolysis mixture slightly lowered the fraction of dehydrogenation products. There is a noticeable decrease in the total conversion that is consistent with a decrease in tem- 
Table IV. Products and dehydrogenation to ethylene loss ratio from sensitized $\mathrm{cw}$ laser-induced decomposition of tetralin (1) in the presence of hydrogen atom chain terminators $a, b$

\begin{tabular}{|c|c|c|c|c|c|c|c|c|c|c|}
\hline \multirow[b]{2}{*}{$\begin{array}{c}\text { chain terminator } \\
\text { (P. torr) }\end{array}$} & \multirow[b]{2}{*}{ time (s) } & \multirow[b]{2}{*}{$\begin{array}{c}\text { conversion. } \\
\% d\end{array}$} & \multirow[b]{2}{*}{$\begin{array}{l}\text { ratio } \\
\frac{(2+5)}{(3+6)} \\
\end{array}$} & \multicolumn{7}{|c|}{ yield, $\% c$} \\
\hline & & & & 2 & $\mathbf{5}$ & 3 & 6 & 4 & 8 & $\begin{array}{l}\text { other } \\
\text { prods. }\end{array}$ \\
\hline none $(-)$ & 120 & 2.7 & 2.1 & 56.6 & 6.6 & 19.2 & 11.0 & 4.8 & 1.8 & - \\
\hline toluene (1.0) & 120 & 0.9 & 1.4 & 53.5 & 4.7 & 35.7 & 6.0 & - & - & - \\
\hline HI (0.2) & 60 & 0.8 & 3.9 & 70.0 & 9.2 & 11.2 & 9.2 & - & - & - \\
\hline HI (1.0) & 60 & 1.0 & 2.3 & 70.0 & trace & 30.0 & trace & - & - & - \\
\hline lodine $(0.25)$ & 60 & 0.2 & 73 & 50.7 & 44.0 & 1.3 & - & - & - & $3.6^{e}$ \\
\hline
\end{tabular}

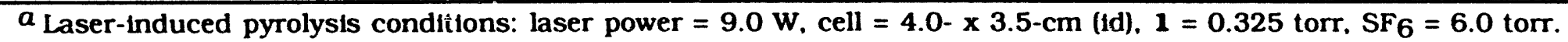
$b^{b}$ See Table I, footnote $b .{ }^{c}$ See Table I, footnote $c$. $d$ See Table I, footnote $d$. ${ }^{e}$ Two products with retention times longer than 6 whose structures were not determined, but are likely to be fodine substitution products. 
perature of the heated gas due to the higher thermal conductivity of toluene. The simultaneous decrease in the transmission of laser light through the cell independently confirms this. 12

When $\mathrm{HI}$ is used as a potential chain terminator, Table IV shows that the total conversion decreases, presumably due to a decrease in reaction temperature. The contribution of dehydrogenation to the overall reaction is however increased relative to ethylene loss. We found that deposits of $I_{2}$ are visible on the cell walls after these pyrolysis experiments. Laser excitation of a mixture of $\mathrm{HI}$ and $\mathrm{SF}_{6}$ alone did not produce any observable $I_{2}$ deposits under similar conditions.

Then I2 was used as a potential chain terminator and as a check to determine if the $\mathrm{I}_{2}$ produced in the $\mathrm{HI}$ experiments above had biased the results. Table IV shows that the amount of dehydrogenation increased markedly. This is likely due to an fodine atom induced dehydrogenation. The direct production of fodine atoms at room temperature by laser photolysis of $I_{2}(45 \mathrm{~mW}, 576.601 \mathrm{~nm}, 20 \mathrm{~min})^{14}$ did not produce any dissociation in 1 . This is not unexpected since there should exist a reasonable energy barrier for the reaction of lodine atom with 1.

We also studied the effect of potential hydrogen-atom assisted dissociation of 1 . Hydrogen atoms can be produced either by room temperature laser photolysis or by $\mathrm{cw}$ laser sensitized reaction at high temperatures. Photolysis of $\mathrm{HI}$ at $308 \mathrm{~nm}$ produces visible deposits of $I_{2}$ on the cell walls, indicating dissociation of $\mathrm{HI}$ to generate hydrogen atoms. A mixture of 1 (0.325 torr). SF6 (6.0 torr) and HI (3.7 torr) was laser Irradiated (308 $\mathrm{nm}, 147 \mathrm{~mJ}$ pulse ${ }^{-1}, 3000$ pulses) in the gas cell used in the laser sensitized experiments after quartz windows were installed. Only four product peaks were found by GCMS analysis, giving a total conversion of $1.4 \%$ of 1 . These have $\mathrm{m} / \mathrm{e}$ of $134(30 \%), 136$ 
(10\%), $136(10 \%)$, and $138(50 \%)$, respectively. These clearly are hydrogen addition products of 1. 1,2-dihydronaphthalene (2) was not detected.

We have also studied the reaction between hydrogen atoms and 1 at elevated temperatures (cw laser-sensitized reaction). Hexamethylethane decomposes to produce hydrogen atoms as an intermediate. ${ }^{13}$ Isobutene $(6.5 \%)$ was identified when a mixture of hexamethylethane (2.0 torr) and $\mathrm{SF}_{6}(6.0$ torr) was irradiated by a $\mathrm{cw}$ laser $(944.2$ $\left.\mathrm{cm}^{-1}, 5.0 \mathrm{~W}, 180 \mathrm{~s}\right)$, Indicating that hydrogen atoms are indeed produced under these conditions. When hexamethylethane ( 2.0 torr) was copyrolyzed with 1 ( 0.30 torr), butylbenzene $(m / e=134)$ was the primary product $(1.1 \%)$. Only a trace of 2 was found. In the absence of hexamethylethane, only a trace of 2 was found in the product analysis of the sensitized pyrolysis of 1 under identical conditions.

\section{Flash vacuum and flow pyrolysis}

The yields of key flash vacuum pyrolysis (FVP) products of tetralin (1) vary with experimental conditions. Product yields are not only effected by the oven temperature but other experimental conditions, such as system pressure and sample temperature, as well.

In the FVP of 1 at $10^{-5}$ torr, the ratio of 1,2-dihydronaphthalene (2) and naphthalene (5) to benzocyclobutene (3) and styrene (6) remains ca. $1(0.90-1.03)$ from 850 to $950^{\circ} \mathrm{C}$ and finally drops to 0.73 at $1000^{\circ} \mathrm{C}$ (Table V. Figure 1). On the other hand, when 1 is pyrolyzed at 0.10 torr a distinct drop in the dehydrogenation to ethylene loss ratio. from 2.70 to 0.72 (Table VI, Figure 1), with increasing pyrolysis temperature is observed. In Figure 1, conversion was plotted rather than oven temperature because the former is a better indicator of the actual reaction temperature. 
Table v. Total recovery of material, conversion, and dehydrogenation to ethylene loss ratio from FVP of tetralin (1) at $10^{-5}$ torr and various oven temperatures $a, b, c$

\begin{tabular}{cccc}
\hline $\begin{array}{c}\text { oven temp., } \\
{ }^{\circ} \mathrm{C}\end{array}$ & $\begin{array}{c}\text { recovery, } \\
\% d\end{array}$ & $\begin{array}{c}\text { conversion, } \\
\% e^{2}\end{array}$ & $\begin{array}{c}\text { ratio } \\
(\mathbf{2}+\mathbf{5}) /(3+6)\end{array}$ \\
\hline 850 & 90.0 & 4.8 & 0.90 \\
900 & 85.6 & 17.2 & 1.03 \\
950 & 80.4 & 34.4 & 0.92 \\
1000 & 76.2 & 65.4 & 0.73 \\
\hline
\end{tabular}

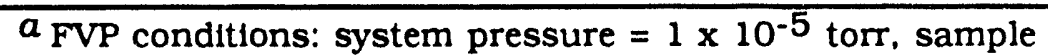
temperature $=0{ }^{\circ} \mathrm{C}$. $b$ See Table I, footnote $b$. Data represent the average of triplicate runs. $c$ See Table A-I in the Appendix of Paper 1, this dissertation, for a more detalled analysis. $d$ Total moles of recovered material divided by moles of starting material used. $e$ Total moles of recovered material minus moles of recovered starting material divided by total moles of recovered material.

The influence of sample temperature on the pyrolysis of 1 was also investigated at three sample temperatures from $-30^{\circ} \mathrm{C}$ to room temperature $\left(900{ }^{\circ} \mathrm{C}, 10^{-5}\right.$ torr $)$. These data are presented in Table VII and clearly show a low sample temperature results in lower conversion and less dehydrogenation relative to ethylene loss.

The possibility that bimolecular or surface reactions were responsible for the above results lead to some additional experiments. To minimize collisions between hot tetralin molecules with each other and with the quartz surface of the oven, tetralin vapor was mixed with a large amount of argon (ca. 4500:1 mole ratio of argon to tetralin). This mixture was introduced into an evacuated pyrolysis oven through a flow system (Figure 2). 


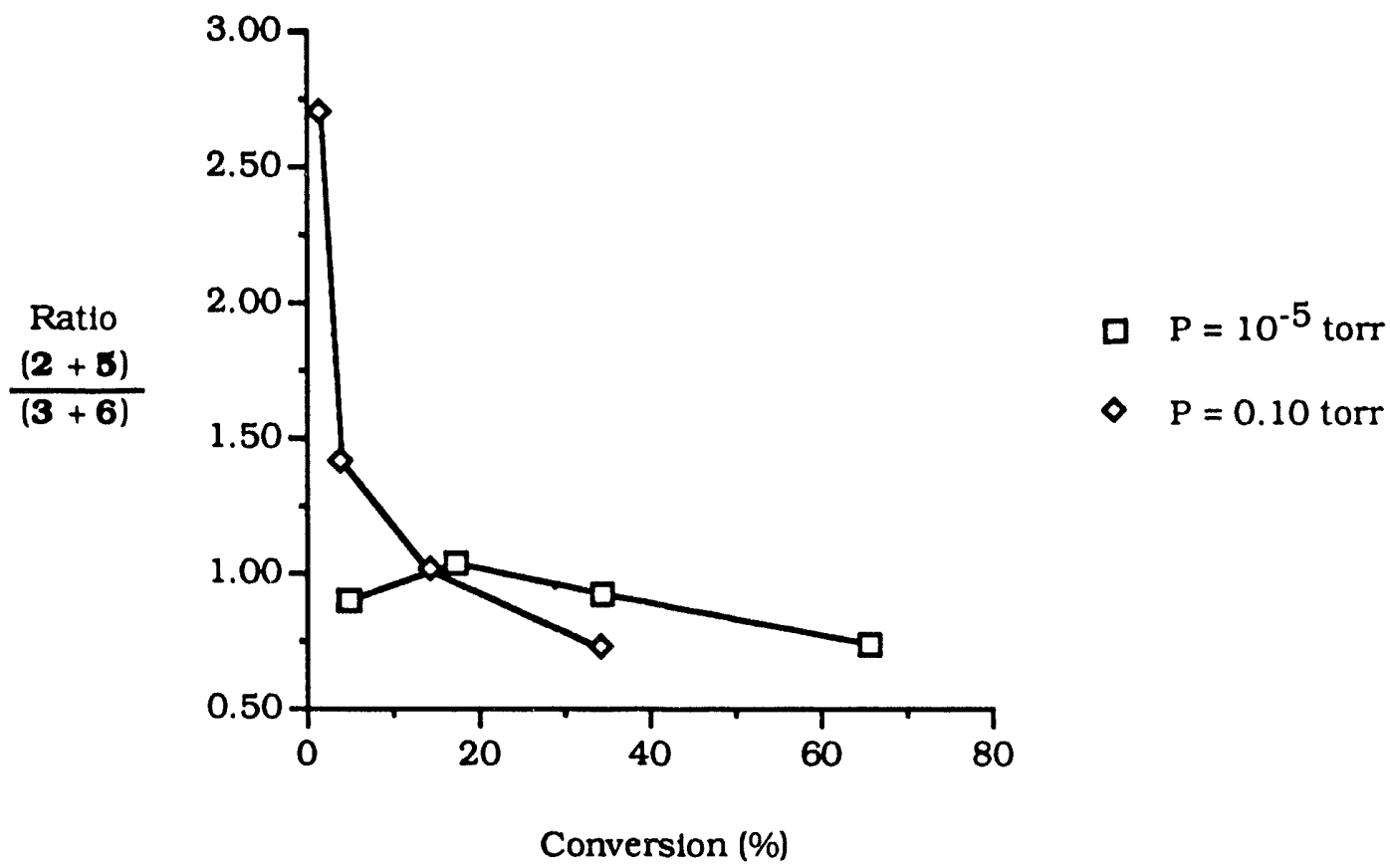

Figure 1. The dehydrogenation to ethylene loss ratio vs. conversion at two system pressures (sample temperature, $0^{\circ} \mathrm{C}$ )

Table vI. Total recovery of material, conversion, and dehydrogenation to ethylene loss ratio from FVP of tetralin (1) at 0.10 torr and various oven temperatures $a, b, c$

\begin{tabular}{cccc}
\hline $\begin{array}{c}\text { oven temp., } \\
{ }^{\circ} \mathrm{C}\end{array}$ & $\begin{array}{c}\text { recovery, } \\
\% d\end{array}$ & $\begin{array}{c}\text { conversion, } \\
\% e^{2}\end{array}$ & $\begin{array}{c}\text { ratio } \\
(\mathbf{2}+\mathbf{5}) /(\mathbf{3}+\mathbf{6})\end{array}$ \\
\hline 750 & 91.8 & 1.4 & 2.70 \\
800 & 92.0 & 3.7 & 1.41 \\
850 & 83.8 & 14.3 & 1.01 \\
900 & 85.2 & 34.3 & 0.72 \\
\hline
\end{tabular}

$a_{\text {FVP }}$ conditions: system pressure $=0.10$ torr, sample temperature $=0{ }^{\circ} \mathrm{C}$. ${ }^{b}$ See Table $\mathrm{V}$, footnote $b$. $^{c}$ See Table A-II in the Appendix of Paper 1, this dissertation, for a more detalled analysis. $d$ See Table $\mathrm{V}$, footnote $d$. $^{e}$ See Table V, footnote $e$. 
Table VII. Total recovery of material, conversion, and dehydrogenation to ethylene loss ratio from FVP of tetralin (1) at $10^{-5}$ torr and various sample temperatures $a, b, c$

\begin{tabular}{cccc}
\hline $\begin{array}{c}\text { sample temp.. } \\
{ }^{\circ} \mathrm{C}\end{array}$ & $\begin{array}{c}\text { recovery, } \\
\% d\end{array}$ & $\begin{array}{c}\text { conversion, } \\
\% \text { e }\end{array}$ & $\begin{array}{c}\text { ratio } \\
(\mathbf{2}+\mathbf{5}) /(3+6)\end{array}$ \\
\hline-30 & 85.2 & 13.4 & 0.39 \\
0 & 86.7 & 20.7 & 0.84 \\
$\mathrm{RT}$ & 80.8 & 30.2 & 2.09 \\
\hline
\end{tabular}

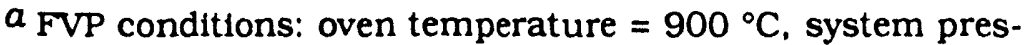
sure $=1 \times 10^{-5}$ torr. $b$ See Table V, footnote $b . c$ See Table A-III in the Appendix of Paper 1, this dissertation, for a more detalled analysis. $d$ See Table $V$, footnote $d$. $e$ See Table $V$, footnote $e$.

When 1 is pyrolyzed under flow conditions (Table VIII), the major products are benzocyclobutene (3) and styrene (6). In fact, ethylene loss exceeds dehydrogenation by a ratio of between 3 and 5 to 1 , over a wide temperature and conversion range.

\section{Secondary Pathways in Tetralin Decomposition}

To develop a complete picture of tetralin thermal decomposition, it was necessary to examine the chemistry of some of the other products. o-Allyltoluene (4) is produced in the flow pyrolysis of tetralin (1) at $800{ }^{\circ} \mathrm{C}$ (Table VIII), along with the other initially formed products, 1,2-dihydronaphthalene (2), benzocyclobutene (3), and styrene (6). At higher temperatures, increasing amounts of styrene (6), 2-methylindan (7). indene (8). and naphthalene (5) are present. To clarify the origin of some to these secondary products, o-allyltoluene (4) and 1,2-dihydronaphthalene (2) were pyrolyzed separately. 
When 4 is pyrolyzed in the flow apparatus (Table IX), the major reaction observed is isomerization of 4 to 7 . At higher temperatures, 7 is further converted to 8 . Numerous other products are produced in smaller amounts, Including 1, 2, 3, 6, and 6. Although small amounts of 3, 5, and 6 appear to be produced directly from 4 below 800 ${ }^{\circ} \mathrm{C}$, It is likely that most of the 2, 3, 6, and 6 observed at higher temperatures result from secondary pyrolysis of 1 .

1,2-Dihydronaphthalene (2) was also pyrolyzed under conditions similar to those used for the flow pyrolysis of 1 and 4. These results are summarized in Table $\mathrm{X}$. As expected, the major product is $\mathbf{5}$. Even at high temperatures, products other than $\mathbf{5}$ constitute only a small percentage of the pyrolysate. 


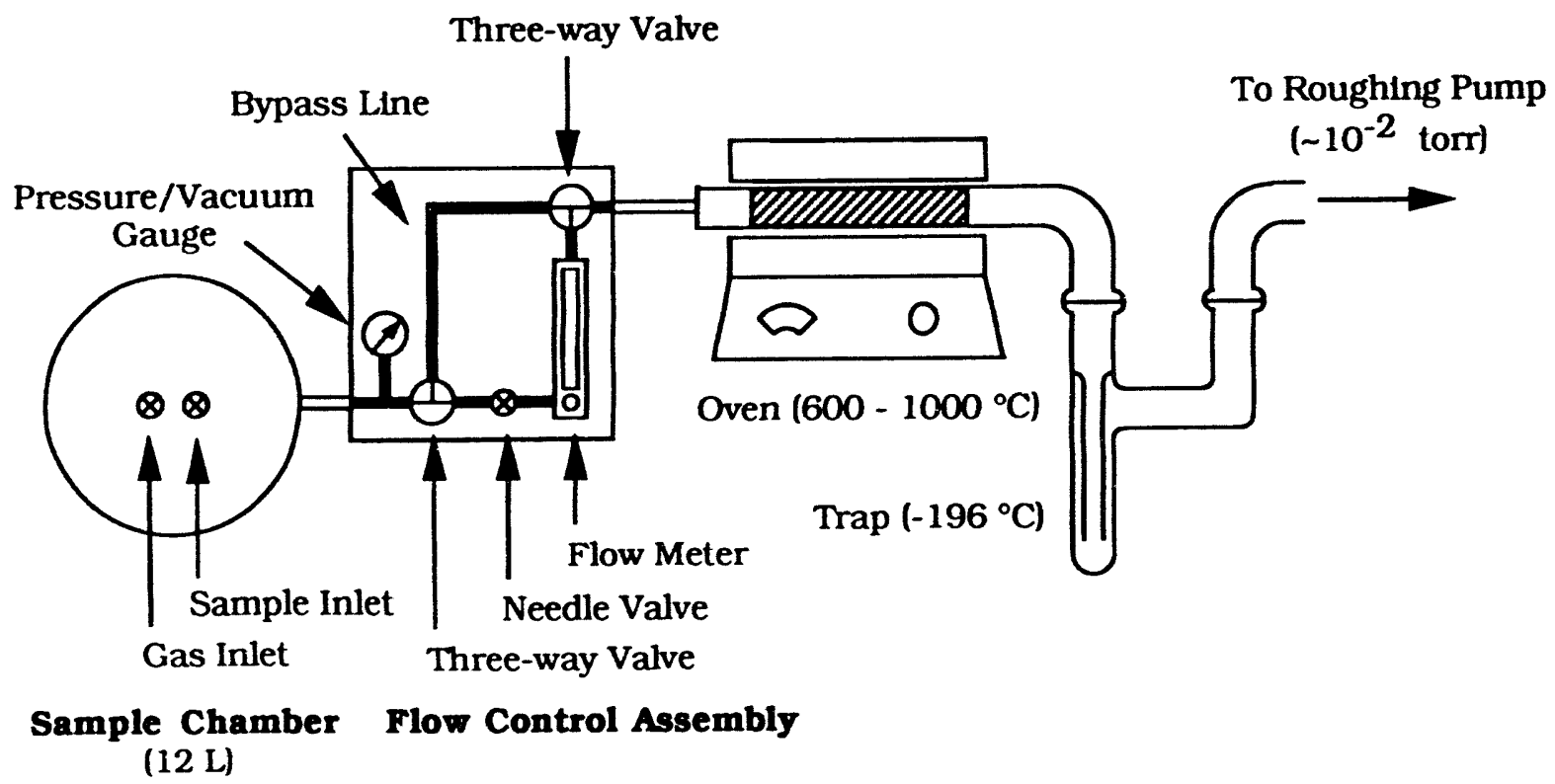

Figure 2. Schematic diagram of flow pyrolysis apparatus 
Table VII. Products and recovered starting material and dehydrogenation to ethylene loss ratio from flow pyrolysis of tetralin (1) at various oven temperatures $a, b$

\begin{tabular}{|c|c|c|c|c|c|c|c|c|c|c|c|c|}
\hline \multirow[b]{2}{*}{$\begin{array}{c}\text { oven temp., } \\
{ }^{\circ} \mathrm{C}\end{array}$} & \multirow[b]{2}{*}{$\begin{array}{l}\text { recovery, } \\
\qquad \% d\end{array}$} & \multirow[b]{2}{*}{$\begin{array}{c}\text { conversion. } \\
\% e\end{array}$} & \multirow[b]{2}{*}{$\begin{array}{l}\text { ratio } \\
\frac{(2+5)}{(3+6)} \\
\end{array}$} & \multicolumn{9}{|c|}{ yield, $\% c$} \\
\hline & & & & 1 & 2 & 5 & 3 & 6 & 4 & 7 & 8 & $\begin{array}{l}\text { other } \\
\text { prods. }\end{array}$ \\
\hline 800 & 89.0 & 1.5 & $0.40 f$ & 98.5 & $0.4 f$ & - & 0.9 & $<0.1$ & 0.2 & - & - & - \\
\hline 850 & 89.2 & 9.3 & 0.28 & 90.7 & 1.1 & 0.5 & 4.7 & 1.1 & 1.1 & 0.6 & 0.2 & - \\
\hline 900 & 93.4 & 22.7 & 0.22 & 77.3 & 1.7 & 1.4 & 9.9 & 4.6 & 1.9 & 1.7 & 1.0 & 0.39 \\
\hline 950 & 85.3 & 53.9 & 0.21 & 46.1 & 2.2 & 5.0 & 13.9 & 20.7 & 2.2 & 2.9 & 4.3 & $2.8 \mathrm{~g}$ \\
\hline
\end{tabular}


Table DX. Products and recovered starting materlal from flow pyrolysis of 0 -allyltoluene (4) at various oven temperatures $a, b$

\begin{tabular}{|c|c|c|c|c|c|c|}
\hline \multirow[b]{2}{*}{ entry } & \multicolumn{6}{|c|}{ yteld, \% c } \\
\hline & $700^{\circ} \mathrm{C}$ & $750^{\circ} \mathrm{C}$ & $800^{\circ} \mathrm{C}$ & $850^{\circ} \mathrm{C}$ & $900^{\circ} \mathrm{C}$ & $950^{\circ} \mathrm{C}$ \\
\hline o-allyltoluene (4) $d$ & 94.0 & 83.6 & 71.0 & 30.9 & 12.7 & 5.8 \\
\hline 2-methylindan (7) & 2.1 & 8.4 & 17.8 & 34.8 & 28.7 & 13.1 \\
\hline Indene (8) & 0.7 & 1.4 & 2.0 & 9.7 & 23.9 & 39.9 \\
\hline tetralin (1) & 0.3 & 0.8 & 2.0 & 5.2 & 5.4 & 3.9 \\
\hline 1.2-dihydronaphthalene (2) & 0.6 & 1.4 & 0.5 & 1.0 & 0.8 & 0.5 \\
\hline naphthalene (5) $d$ & 0.1 & 0.3 & 0.1 & 0.9 & 1.1 & 2.5 \\
\hline benzocyclobutene (3) & - & 0.2 & 0.5 & 1.4 & 2.8 & 2.2 \\
\hline styrene (6) & 一 & - & - & 0.4 & 2.3 & 5.7 \\
\hline other products & $2.4^{e}$ & $3.9^{e}$ & $6.3^{e}$ & $15.9^{e}$ & $22.4^{e}$ & $26.8^{e}$ \\
\hline recovery $f$ & 84.0 & 81.2 & 88.3 & 74.0 & 80.1 & 69.8 \\
\hline conversion $g$ & 6.0 & 16.4 & 29.0 & 69.1 & 87.3 & 94.2 \\
\hline $\begin{array}{l}a \text { Flow pyrolysis condition } \\
\text { (Ar), residence time }=0.31 \\
d \text { Starting material (yleld, } \%) \\
\text { (0.3). }{ }^{e} \text { See Table A-V in the } \\
\text { analysis. } f \text { See Table V, footn }\end{array}$ & $\begin{array}{l}\text { system } \\
b \text { See }\end{array}$ & $\begin{array}{l}\text { ressure } \\
\text { able } \mathrm{V} \text {, }\end{array}$ & $\begin{array}{l}\text { this } \\
\text { footnot }\end{array}$ & $\begin{array}{l}c \text { torr. flo } \\
c \text { See T }\end{array}$ & $\begin{array}{l}\text { rate }=2 \\
\text { le VIII. }\end{array}$ & $\mathrm{mL} \min$ \\
\hline
\end{tabular}


Table $\mathbf{X}$. Products and recovered starting materlal from flow pyrolysis of 1,2-dihydronaphthalene (2) at various oven temperatures $a, b$

\begin{tabular}{|c|c|c|c|}
\hline \multirow{2}{*}{ entry } & \multicolumn{3}{|c|}{ yleld, \% c } \\
\hline & $800^{\circ} \mathrm{C}$ & $850^{\circ} \mathrm{C}$ & $900^{\circ} \mathrm{C}$ \\
\hline 1,2-dihydronaphthalene (2) $d$ & 89.9 & 73.2 & 31.1 \\
\hline naphthalene (5) & 8.7 & 23.4 & 61.7 \\
\hline other products & $1.4 e$ & $3.4^{e}$ & $7.1 e$ \\
\hline recovery $f$ & 80.1 & 90.3 & 83.1 \\
\hline conversion $g$ & 10.1 & 26.8 & 68.9 \\
\hline \multicolumn{4}{|c|}{ 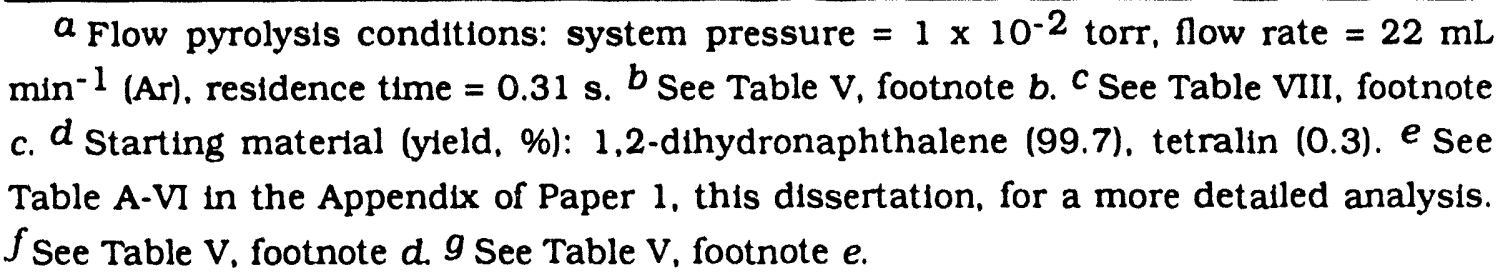 } \\
\hline
\end{tabular}




\section{DISCUSSION}

\section{Dehydrogenation v8. Ethylene Loss in Tetralin Decomposition}

\section{Laser-Induced decomposition 6}

In the multiphoton dissociation (MPD) of tetralin (1), ethylene loss to form benzocyclobutene (3) and styrene (6) is clearly the major reaction pathway (Table I). The results for the MPD of 1 in this work agree with those in the previous study. ${ }^{5}$ It is diffcult to compare the fluence of these MPD experiments with those used earlier ${ }^{15}$ but considering the beam properties and the optical arrangements, we believe they are comparable. Though we observe no indene (8) and more 1,2-dihydronaphthalene (2) is observed here than previously reported, the conclusion that ethylene loss is the main decomposition channel in MPD is confirmed.

In this work, the predominant reaction of 1 in the continuous wave (cw) and pulsed laser-induced sensitized decompositions (Table II. Table III) is dehydrogenation to form 1,2-dihydronaphthalene (2) and naphthalene (5). These results are in disagreement with the previous study, 5 which found that ethylene loss was the main decomposition reaction. Since the MPD results from the two studies agree, it is unlikely that the discrepancies in the pulsed laser sensitized experiments are due to differences in the tetralin purity or analytical procedures used, nor do nonhomogeneous reactions provide a satisfactory explanation.

In the pulsed laser decomposition of 1 shown in Table II, the amount and fraction of ethylene loss increases with laser energy. In the two SiF 4 sensitized pyrolyses, the difference in laser powers is responsible for the results. Though $0.11 \mathrm{~J}$ does not seem too different from $0.09 \mathrm{~J}$, our laser shows large pulse-to-pulse variations 
at the maximum output range. Although the average energy per pulse is $0.11 \mathrm{~J}$, there are individual pulses as high as $0.15 \mathrm{~J}$ throughout the experiment. It is the pulses with the highest power that dominate the pyrolysis process, since yields are exponentially dependent on temperature. The substantially increased yield at $0.11 \mathrm{~J}$ also confirms a higher reaction temperature. Unfortunately, we were not able to obtain still higher output levels from our laser at the $\mathrm{SIF}_{4}$ wavelength to observe a clear-cut cross-over of the two reaction channels.

Tetralin decomposition sensitized by $\mathrm{SiF}_{4}$ or $\mathrm{SF}_{6}$ based on $\mathrm{cw}$ IR laser excitation has not been reported previously. A major consideration is that one can control the power levels and the power densities much more reliably than with the corresponding pulsed lasers. 16 One expects to find a steady-state temperature gradient starting at a high level at the center of the laser beam (due to cumulative absorption), dropping quickly outside the irradiated region, and eventually equilibrating to the cell walls along a slower temperature gradient than for the pulsed laser. 12 The results in Table III show that the major decomposition reaction of 1 under $\mathrm{cw}$ laser-induced sensitized conditions is dehydrogenation.

To assess the contributions of surface reactions to the overall decomposition process, we studied the dependence of the absolute ylelds of products on the size and shape of the sample cell. The $\mathrm{KBr}$ windows in every case should contribute roughly the same amount of surface reactions since the contact areas as well as the distances from the hot gas column are comparable. In fact, since less depletion of laser light and less area for thermal conduction exist in the smallest cell, surface temperatures at the windows there should be the highest. The decomposition rates decrease substantially in the series of experiments from large to small cells indicating that surface reactions at the cell windows cannot be important in the cw laser-induced decomposition. 
As for the Pyrex cell walls, the first two absolute yields (4- x 3.8-cm (id) cell, $121 \mathrm{x}$ $10^{-12} \mathrm{~mol} \mathrm{~s}^{-1}: 4-\times 2.8-\mathrm{cm}\left(\right.$ id) cell, $52 \times 10^{-12} \mathrm{~mol} \mathrm{~s}^{-1}: \mathrm{R}_{1}: \mathrm{R}_{2} \approx 2: 1$ ) show a decrease in the rate of formation of 1,2-dihydronaphthalene (2) and naphthalene (5) (the only major products) that is better explained by the difference in the volume of gas heated $\left(V=\pi r^{2} h\right.$, $\left.\mathrm{V}_{1}: \mathrm{V}_{2}=(3.8)^{2}:(2.8)^{2} \approx 2: 1\right)$ than by the decrease in avallable surface area $(\mathrm{S}=2 \pi \mathrm{rh}$, $\left.S_{1}: S_{2}=3.8: 2.8 \approx 1: 1\right)$. The Pyrex surface area decreased by a factor of four in the last three cells (4- $\times 2.8-\mathrm{cm}$ (id) cell, $52 \times 10^{-12} \mathrm{~mol} \mathrm{~s}^{-1}: 2-\times 2.8-\mathrm{cm}$ (id) cell, $1.9 \times 10^{-12} \mathrm{moi}$ $\mathrm{s}^{-1} ; 1-\times 2.8-\mathrm{cm}(\mathrm{dd})$ cell, $0.21 \times 10^{-12} \mathrm{~mol} \mathrm{~s}^{-1}$ ) but the yields decreased by a factor of 360 .

It has been shown 12 that smaller cells provide shorter distances for heat conduction from the center of the cell to the cell walls. We confirmed that the smallest cell $(1-\times 2.8-\mathrm{cm})$ did feel hot to the touch during laser pyrolysis compared to the larger cells. Since the cell walls are close to room temperature, the heated gas column has a lower temperature in smaller cells for the same incident laser power and this accounts for the dramatic decrease in absolute rates in these experiments. One can therefore conclude that nelther the Pyrex cell walls nor the $\mathrm{KBr}$ windows contribute to the dehydrogenation of 1 through surface reactions.

Our deuterium labeling results indicate that 1,2-elimination is the primary mode (ca. $80 \%$ ) of dehydrogenation but that ca. 10\% 1,4- and 10\% 2,3-elimination are also involved. However, it is not possible to conclude whether the loss of hydrogen from 1 involves intermolecular processes (e.g., abstraction) or whether isotopic scrambling occurs after decomposition.

The large amount of HD produced in the pyrolysis of a 1:1 mixture of 1 and $d^{12-1}$ indicates that at least $80 \%$ of the hydrogen is formed by intermolecular pathways. Previous workers $5 \mathrm{~b}$ also studied the decomposition of deuterated tetralin 
derivatives and concluded that the hydrogen loss was consistent with an $80 \%$ stepwise process.

The observation of an excess of dehydrogenation products (2 and $\mathbf{5}$ ) over ethylene-loss products ( 3 and 6 ) at low temperatures in itself cannot confirm that the former is the unimolecular decomposition reaction with the lower energy barrier. It is possible that dehydrogenation products are formed as a result of radical chains, which magnify the contributions from that channel. We have already shown above that surface-catalyzed reactions are not important in the production of 2 and $\mathbf{5}$. The isotopic studies Indicate that hydrogen atoms are formed during pyrolysis. Presumably these can cycle (by reaction with 1) to produce more dehydrogenation products.

Although chain-liduced dehydrogenation may be occurring under our laser-induced pyrolysis conditions, it is not clear why such chains should be more im. portant here than in the previous work. 5 In pulsed laser experiments, the hot zone quickly expands and is cooled by the surrounding gas to quench long chain processes. in $\mathrm{cw}$ laser experiments, gases in the heated zone migrate outwards and are also cooled by the surrounding gas. Although the temperature profiles are different in the two cases, the time periods involved for migration from the heated zone to the cold walls are quite simular.

The implication is that the earlier pulsed laser-sensitized study 5 was performed at an effective temperature higher than either the pulsed or cw laser experiments reported here. The sensitizer is excited to high vibrational levels following multiphoton absorption (pulsed experiments). Since $V \rightarrow V$ energy transfer to the reactant is highly favored (compared to $\mathrm{V} \rightarrow \mathrm{T}$ ). the calculated maximum temperature ${ }^{5 \mathrm{~b}}$ for pulsed experments does not adequately describe the non-Boltzmann excitation of the reactants. 


\section{Flash vacuum and flow pyrolysis}

The interpretation of the results of the FVP of tetralin (1) at different system pressures and sample temperatures are not clear-cut. In the initial FVP of 1 , there was a marked difference in the chemistry of the pyrolysis at $10^{-5}$ torr and 0.10 torr. Changing the systers pressure results in different amounts of dehydrogenation relative to ethylene loss at comparable conversions.

The system pressure is one of the factors that determines the residence time of sample molecules in the pyrolysis oven. However, a change in the residence time of 1 in the pyrolysis oven should have no effect on the relative amounts of dehydrogenation and ethylene loss at a given effective temperature if both of the pathways are unimolecular processes. If both 1.2-dihydronaphthalene (2) and benzocyclobutene (3) had been produced by the unimolecular decomposition of 1 , the dehydrogenation to ethylene loss ratio would have been determined by the ratio of the rate constants for their formation. If this were the case, one might expect the curve representing the ratio of dehydrogenation to ethylene loss (Figure 1) to show the same trend regardless of the system pressure. This is clearly not the case. At low conversion, there is a marked difference between the almost 3 to 1 excess of dehydrogenation to ethylene loss observed at 0.10 torr and the 1 to 1 ratio observed at $10^{-5}$ torr.

Ultimately, this leads to the conclusion that a substantial portion of either the dehydrogenation or the ethylene-loss products are not produced in an unimolecular gas-phase reaction of $\mathbf{1}$. However, it is difficult to imagine how surface catalytic effects or bimolecular reactions would effect ethylene loss. Only catalytic or bimolecular dehydrogenation remain as possible explanations of the variable results from the FVP of 1 with different system pressures and sample temperatures. Catalytic dehydrogenation on the quartz surface should be favored under conditions that maximize surface contact 
and minimize collisions between sample molecules, while bimolecular decomposition should be favored under conditions that increase the probability of collisions between sample molecules.

Surface catalytic dehydrogenation would be minimized by short residence time at low system pressure $\left(10^{-5}\right.$ torr). This could explain the smaller amounts of dehydrogenation products 1,2-dihydronaphthalene (2) and naphthalene (5) produced when 1 was pyrolyzed at $10^{-5}$ torr (Table V. Figure 1) as compared to 0.10 torr (Table VI. Figure 1). However, surface effects cannot explain the prevalence of dehydrogenation at high tetralin sample temperature (Table VII). Catalysis on the quartz surface should be most evident when collisions between tetralin molecules are at a minimum; 1.e., when the tetralin vapor pressure is low (at low sample temperature). Contrary to this explanation, Table VII shows that high tetralin vapor pressure (at high sample temperature) favors dehydrogenation. Surface catalytic dehydrogenation is also inconsistent with the results from laser pyrolysis, vide supra.

A bimolecular reaction neatly explains the prevalence of dehydrogenation at high tetralin pressures (Table VII). The increased probability of collisions between sample molecules should favor a bimolecular reaction: therefore, more dehydrogenation and increased conversion will result from the high tetralin pressure at high sample temperatures. Rationalizing the system pressure effect with bimolecular dehydrogenation is less straightforward. The residence time could be insufficient for significant bimolecular collisions to occur at low system pressure ( $10^{-5}$ torr). At high system pressure $(0.10$ torr). bimolecular reactions are important at low temperature but the unimolecular gas-phase reaction of 1 , 1.e., ethylene loss, overcomes bimolecular dehydrogenation at higher temperatures, producing the change in the relative amounts of dehydrogenation to ethylene loss observed (Figure 1). 
Flow pyrolysis of 1 was performed to eliminate both surface catalytic and bimolecular reactions and to determine the actual unimolecular decomposition products of 1 . In the flow pyrolysis experiment, energy is transferred from the oven walls to the argon and then to the tetralin through collisions. Surface effects are minimized hecause wall to tetralin collisions should be minor. The high dilution reduces collisions between hot tetralin molecules and other tetralin molecules or reactive species from its decomposition; therefore, bimolecular reactions should be minimized under these conditions. The experiments (Table VIII) show that ethylene loss to form 3 and 6 the lowest energy gas-phase unimolecular decomposition reaction of 1.

Thus, it is likely that a bimolecular dehydrogenation reaction is responsible for the excess production of $\mathbf{2}$ and $\mathbf{5}$ observed at low temperature and conversion under some FVP conditions and in the laser-induced decomposition of 1 . The combined evidence from the laser-induced and flash vacuum pyrolysis experiments reported here is inconsistent with heterogeneous surface catalysis.

\section{Primary Pathways in Tetrallin Decomposition}

We can propose two mechanisms for the bimolecular dehydrogenation of tetralin (1). The first is an autocatalytic intramolecular hydrogen atom transfer (Scheme II). The key step in the first proposed mechanisin is the intermolecular transfer of a hydrogen atom from the benzylic position of 1 to a double bond conjugated to an aromatic ring. Unimolecular decomposition products or impurities, such as 1,2-dihydronaphthalene (2) and styrene (6), could initiate the process to produce radicals 9 and 10 , both of which undergo cleavage of a $\beta$ hydrogen to regenerate 2 and 6 , respectively. The 


\section{Scheme II}

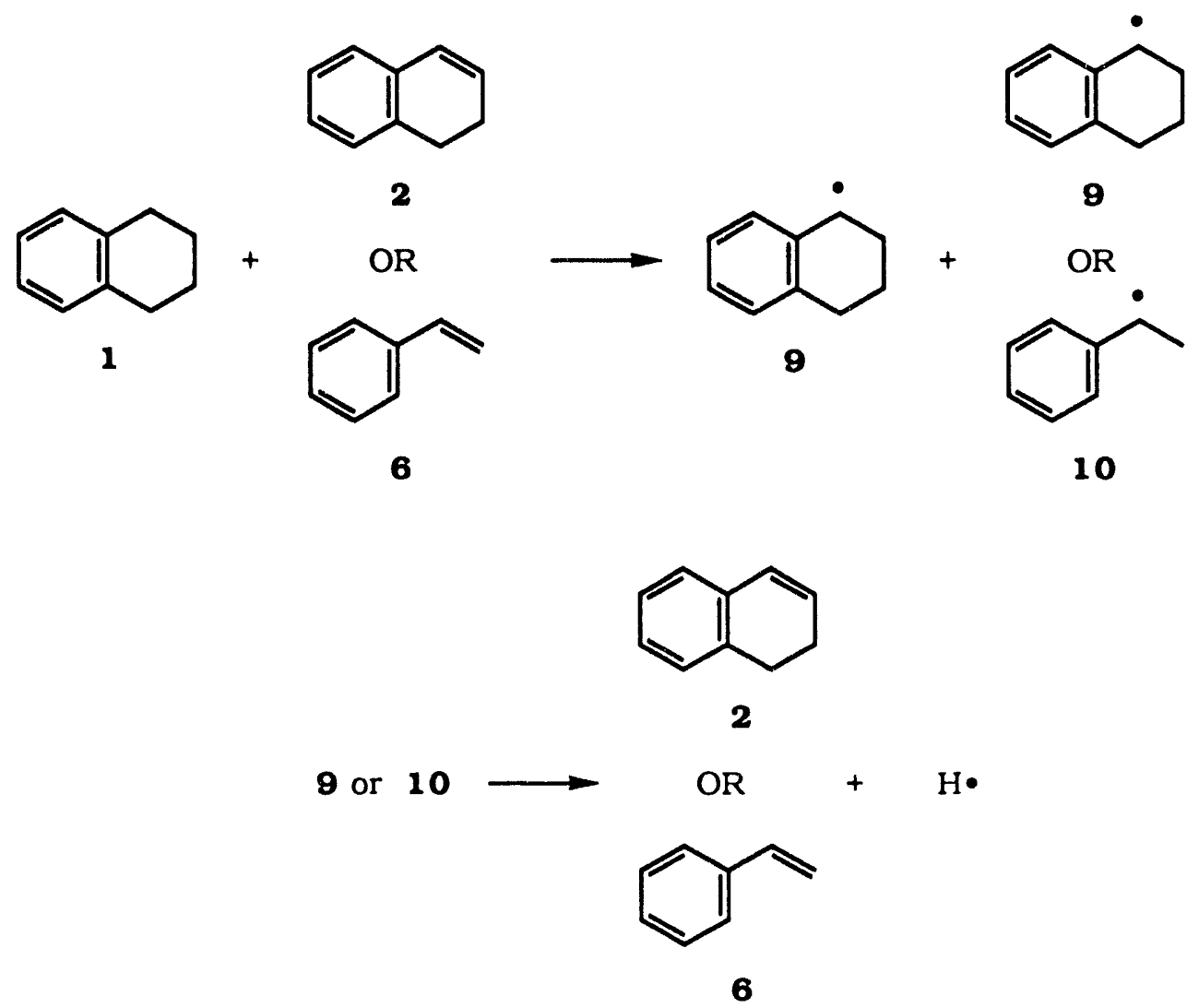

production of 2 would then be autocatalytic. The calculated ${ }^{17} \Delta \mathrm{H}^{\circ}$ for this hydrogen atom transfer reaction is between $31-34 \mathrm{kcal} \mathrm{mol}^{-1}$, which is not unreasonable in this temperature range. Two other examples of this type of reaction are found in the disproportionation of 1,2-dihydronaphthalene (2) $3,18 \mathrm{e}$ and 9,10-dihydroanthracene. 3,19

A second possible mechanism is the hydrogen atom chain in Scheme III. The hydrogen atom is sufficiently reactive to abstract either the $\alpha$ or $\beta$ hydrogen from 1 to form the 1-tetryl (9) and 2-tetryl (11) radicals. Previous examples of this type of chain reaction have been observed in the decomposition of toluene 20 and in the disproportionation of $2^{3,18}$ at higher temperatures. 


\section{Scheme III}

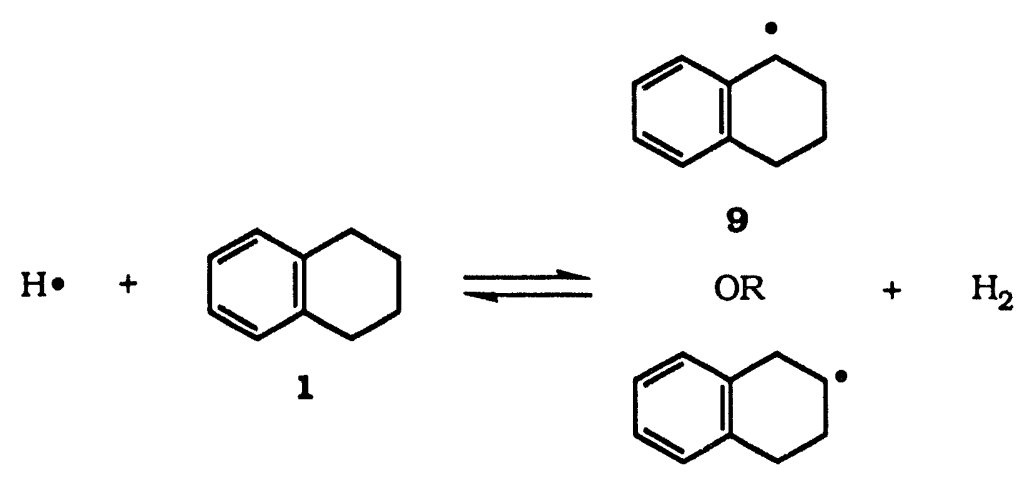

11

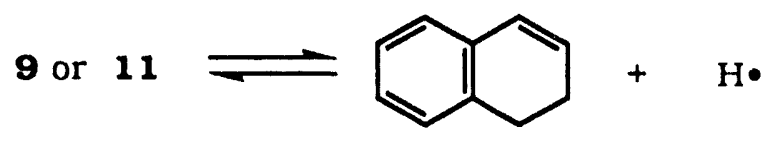

2

There is some evidence for the presence of a hydrogen atom chain operating under the conditions of the experiments reported here. In the laser-induced pyrolysis of 1 (Table IV), there was a small, though not dramatic, reduction in the relative portions of dehydrogenation to ethylene-loss products in the presence of toluene. However, addition of the chain terminators to the sample cell also reduces the temperature and complicates the analysis of these experiments. A substantial increase in the dehydrogenation of 1 occurs in the presence of $I_{2}$. This increase in the amount of 2 and 5 is

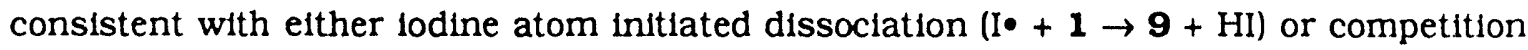
with the recombination of tetryl radicals with hydrogen atoms $\left(\mathrm{I}_{2}+\mathrm{H} \bullet \rightarrow \mathrm{HI}+\mathrm{I} \bullet\right.$ or $\mathrm{I} \bullet+$ $\mathbf{9} \rightarrow \mathrm{HI}+\mathbf{2})$.

On the other hand, the observation of only hydrogen addition products from the laser-induced decomposition of 1 in the presence of hydrogen atoms is reported in this paper. These results would seem to indicate that abstraction by hydrogen atom, 
required for the chain decomposition, is not a favored process. In the room temperature photolysis of HI, the expected tpso addition of hydrogen atom to 1 leads to the formation of radical 12 (Scheme IV). Cleavage of 12 and subsequent trapping of the primary radical 13 by HI, leads to the formation of butylbenzene (14). Trapping of radical 12 by $\mathrm{HI}$ would lead to $1,2,3,4,4 \mathrm{a}, 5,6,8 \mathrm{a}$-octahydronaphthalene (15), 1,2 3,4 4a,5,8,8a-octahydronaphthalene (16), and decalin (17). This scheme is consistent with the molecular weights of the observed products (one of $m / e 134$, two with $m / e 136$, and one with $m / e$ 138).

In the high temperature laser-induced decomposition of 1 in the presence of hexamethylethane, 14 was the major product observed. Little or no 2, formed from $\beta$-hydrogen loss from 1-tetryl radical (9), was found in either laser experiment. The previously reported ${ }^{7}$ shock tube decomposition of 1 in the presence of hexamethylethane. however, resulted in increased dehydrogenation. The discrepancy between hydrogen atom addition to 1 in our laser studies, on the one hand, and abstraction in the shock

\section{Scheme IV}

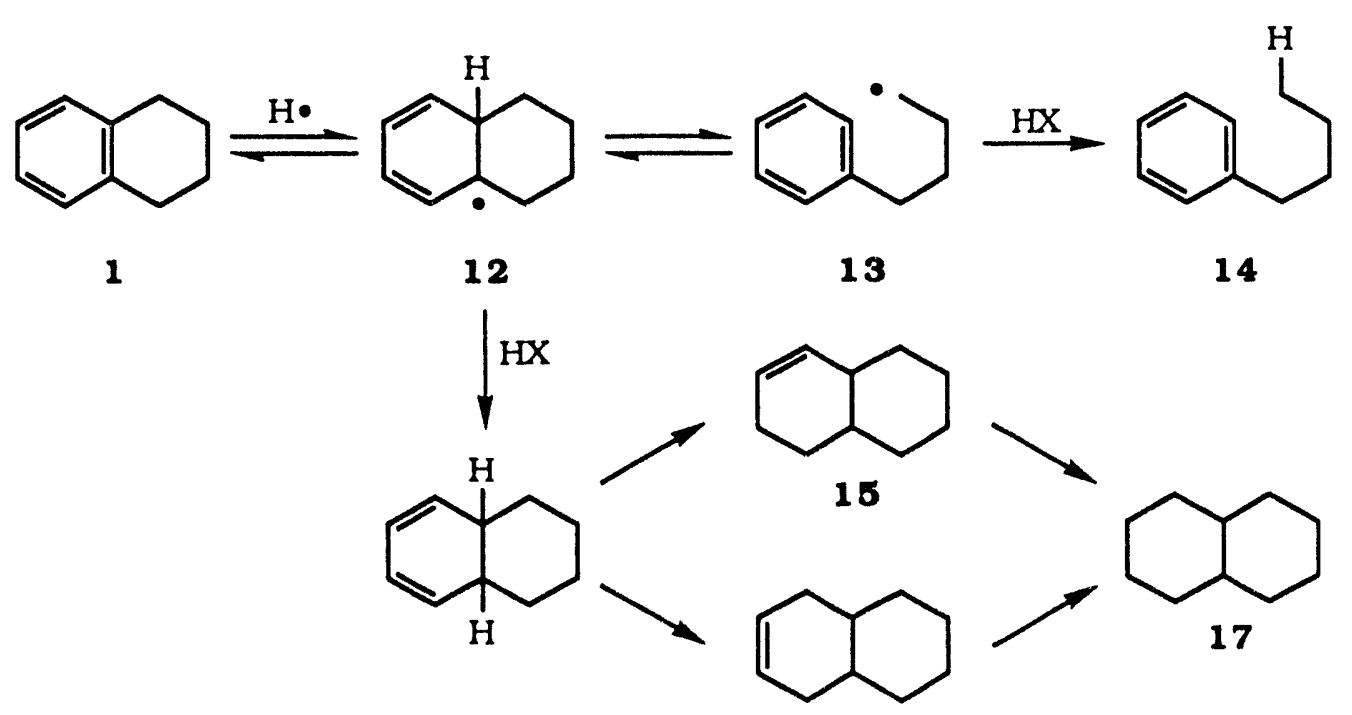

16 
tube results, on the other, can be reconclled as follows. In the studies reported here, a large excess of hydrogen atoms was used, while in the shock tube experiments 1 was in excess. It is possible that, with a large excess of hydrogen atoms, any 2 produced by abstraction is consumed by the readdition of hydrogen atom to the double bond. Alternately, if hydrogen atom addition is reversible, a large excess of hydrogen atoms may be required to favor addition.

Although the evidence is not overwhelming, we can state that hydrogen atom chains (Scheme III) are involved in tetralin decomposition under some conditions. We cannot, however, rule out the first bimolecular mechanism (Scheme II). It is possible that under some conditions both mechanisms operate, as was found to be the case for the disproportion of $2.22 \mathrm{e}$

In the flow pyrolysis of tetralin (1), there is a residual amount of dehydrogenation so we must entertain the possibility of a unimolecular dehydrogenation pathway. The most likely intermediate is the diradical 18 (Scheme V) formed from breaking the benzylic carbon-carbon bond, the weakest bond in 1 . Three possible reaction routes are possible for diradical 18. To produce a net hydrogen-loss product, cleavage of the $\beta$-carbon-hydrogen bond of 18 is required. This would lead to the formation of o-allylbenzyl radical (19), which could close either to the kinetically favored 2-indanylmethyl radical (20) or the thermodynamically more stable 2-tetryl radical (11). The cyclization of 19 should be reversible at these temperatures and products from 11 should predominate. The major product formed by cleavage of the $\beta$ hydrogen of 11 is 2 . To confirm this, we produced radical 19 by the pyrolysis of the bis oxalate ester of o-allylbenzyl alcohol. 21 When this oxalate is pyrolyzed, the major product is 1,2-dihydronaphthalene (2).

A second reaction of diradical 18 is intramolecular disproportionation to form o-allyltoluene (4). This intramolecular hydrogen atom abstraction is likely to occur if 18 


\section{Scheme V}

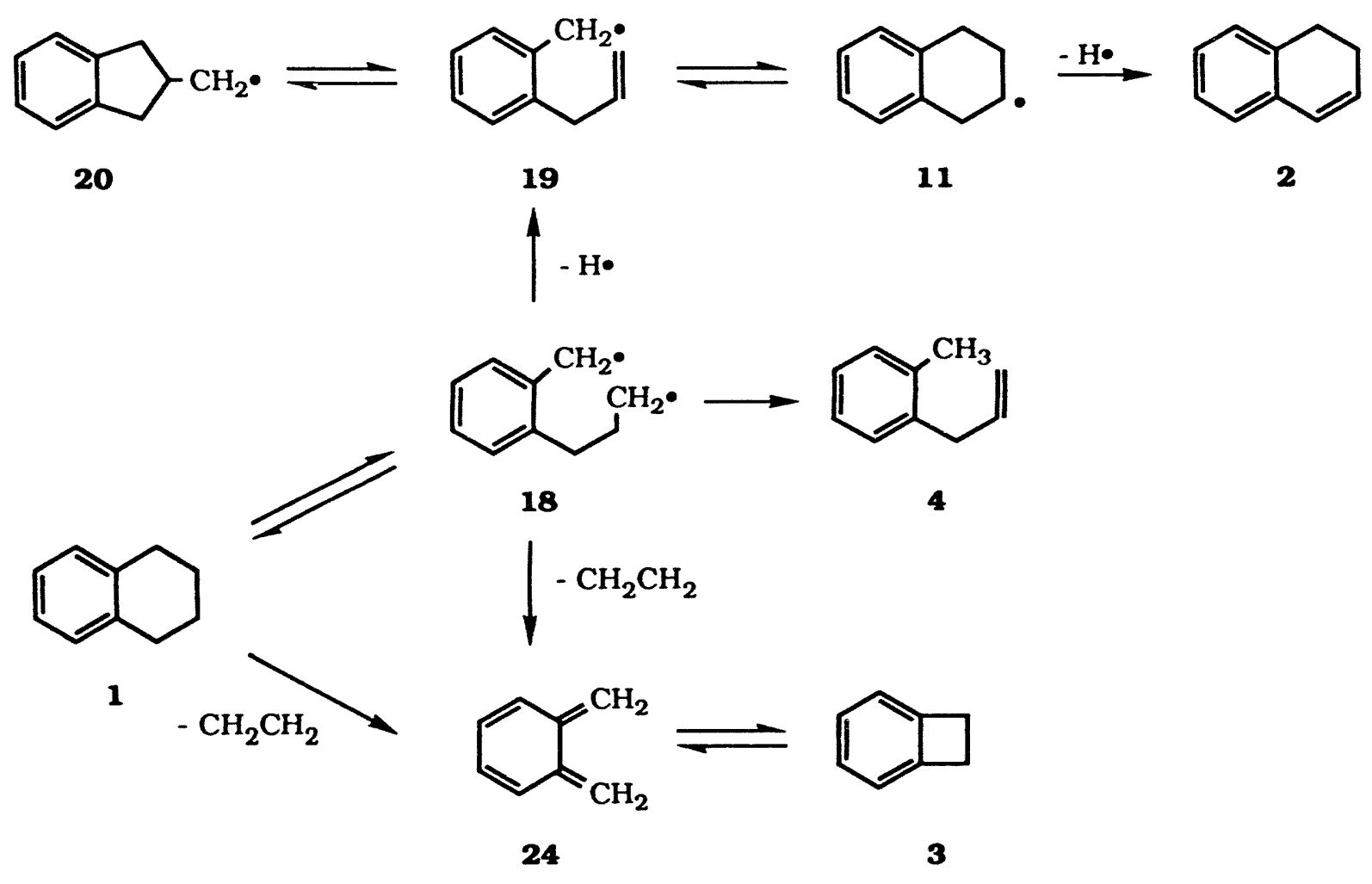


is formed. The product 4 was formed in the decomposition studies reported here. Additionally, 4 was also observed in the pyrolysis of 9-methylenespiro[3.5]nona-5.7-diene (21), 22 3-benzocycloheptenone (22), 23 and 1,3,4,5-tetrahydro-2-benzothie-

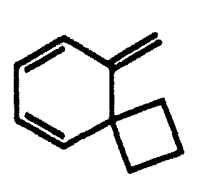

21<smiles>O=C1CCCc2ccccc2C1</smiles>

22

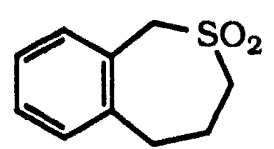

23

pin-2,2-dioxide (23), 23 model systems expected to produce 18. o-Allyltoluene (4) was also formed in room temperature photolysis of 22.23

The third possible reaction path for diradical 18 is cleavage of the $\beta$-carbon-carbon bond leading to the formation of o-xylylene (24) and ultimately to benzocyclobutene (3). The cleavage of a carbon-carbon bond is thermodynamically more favorable than $\beta$-hydrogen loss in normal alkyl radicals; however, geometric constraints required to form 24 and the resulting loss of aromaticity may make the carbon-carbon bond cleavage of 18 less favorable than in other systems. Additionally, the loss of cyclohexene from cis- and trans-1,2,3,4,4a,9,9a,10-octahydroanthracene appears to be concerted. ${ }^{41}$ Although the loss of cyclohexene from these precursors may not be a good model for the loss of ethylene from tetralin (1), we must at least entertain the possibility that ethylene loss from 1 is concerted.

None of the above model systems (21, 22, or 23) for the formation of diradical 18. produces ethylene-loss products. If 18 is formed, clearly the loss of ethylene is not favorable. However, we cannot be certain that 18 is actually formed in the pyrolysis of 21. 22, or 23: although, as noted above, the formation of 4 is consistent with the presence of this radical. The activation parameters for the loss of ethylene from 1 do not preclude concerted ethylene loss. We do not believe there is enough evidence to make a definittve conclusion on this matter. 


\section{Secondary Pathways in Tetralln Decomposition}

We have also examined the decomposition of the primary pyrolysis products of tetralln (1). The primary ethylene-loss product, benzocyclobutene (3), decomposes to

styrene (6). This transformation has been studied previously. 24 Nothing unusual was found in the pyrolysis of 1.2-dihydronaphthalene (2). Naphthalene (5) was the major product (Table $\mathrm{X}$ ) with only minor amounts of other products observed.

In the flow pyrolysis of o-allyltoluene (4), isomerization to 2-methylindan (7) was observed (Table LX). Loss of a methyl from 7 results in the formation of indene (8). Although there : numerous minor prodincts $(<2 \%), 4,7$, and 8 constitute ca. $60 \%$ of the product mixtu:e even at $950{ }^{\circ} \mathrm{C}$. At this temperature, over $90 \%$ of the o-allyltoluene (4) has been conver. $d$ to products. Clearly 4 is the primary source of 8 produced in the pyrolysis of 1.

We have proposed 25 an intramolecular hydrogen atom transfer to account for the transformation of 4 to 7 . Transfer of the benzylic hydrogen of 4 to the terminal end of the double bond would form the diradical 25, which would close to form 7 (Scheme VI). Transfer of the benzylic hydrogen to the internal end of the double bond of 4 would form diradical 18. Closure of this radical should form tetralin (1), which is the highest yield minor product found. Many of the minor products formed in the pyrolysis of 4 probably result from the secondary pyrolysis of 1 . This can be seen by examining the data in Table IX. The amount of 1 produced increases steadily up to $850^{\circ} \mathrm{C}$, levels off at $900^{\circ} \mathrm{C}$ and drops at $950^{\circ} \mathrm{C}$. At the same time the major decomposition products of 1 , benzocyclobutene (3) and styrene (6) are produced in substantial amounts only above $850^{\circ} \mathrm{C}$. 
- 9.8

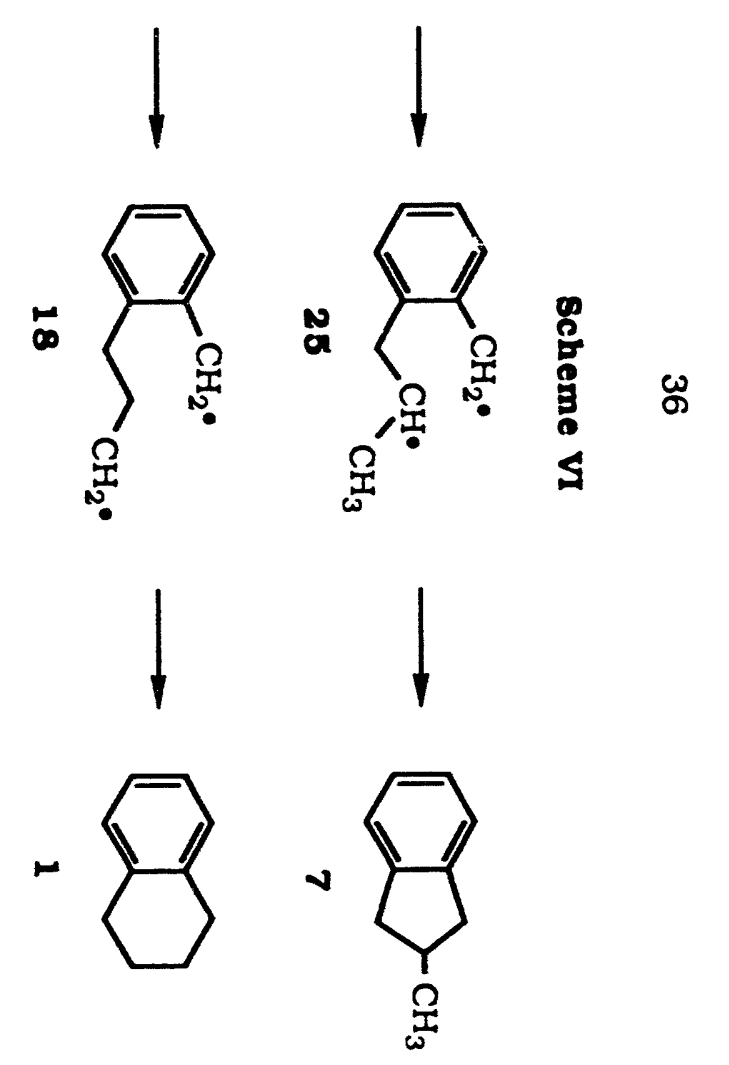




\section{CONCLUSION}

In this paper, we present new results on the thermal decomposition of tetralin (1) under sensitized laser-induced pyrolysis conditions under both $\mathrm{cw}$ and pulsed laser excitation. We have found dehydrogenation to predominate at low temperatures in these experiments. We have also examined the thermal chemistry of 1 under FVP and flow pyrolysis conditions. Our flow experiments show that the lowest energy unimolecular gas-phase decomposition channel for 1 is ethylene loss. A bimolecular dehydrogenation reaction, possibly a hydrogen atom chain, is responsible for greater amounts of hydrogen-loss products observed under some conditions in the decomposition of 1 . In none of our pyrolysis experiments, whether laser-induced or under standard pyrolysis conditions, did we find any evidence of heterogeneous catalytic reactions on surfaces. We can conclude that MPD favors the lowest energy unimolecular decomposition channel while laser-sensitized pyrolysis (cw or pulsed) can lead to homogenous bimolecular reactions as well.

We have observed the faclle transformation of o-allyltoluene (4) to 2-methylindan (7). which we propose occurs through an intramolecular hydrogen atom transfer from the benzylic methyl group to the double bond of 4. Loss of a methyl from 7 leads to the formation of indene (8). We have identified the transformation 4 to 7 to 8 as the major source of 8 in the gas-phase thermal decomposition of 1. 


\section{EXPERIMENTAL SECTION}

\section{Seneral Procedures}

\section{Apparatus}

Laser-induced pyrolysis 6 The experimental arrangements were very sim1lar for the three types of laser studies: infrared pulsed laser sensitized pyrolysis, infrared pulsed laser multiphoton dissociation (MPD), infrared continuous wave (cw) laser sensitized pyrolysis. A schematic diagram of the experimental arrangement for the pulsed laser sensitized pyrolysis is shown in Figure 3. A grating-tuned TEA $\mathrm{CO}_{2}$ laser (Lumonics, Model 102) was used as the pulsed laser. The laser beam was defined with a $0.8-\mathrm{cm}$ pinhole. The intensity profle was tophat shaped with variations of $30 \%$ across the beam. The laser pulse had a $150-n s$ peak and a $2-\mu$ s tail. The unattenuated energy of the laser beam was $0.11 \mathrm{~J}_{\text {pulse }}^{-1}$ at $1027.4 \mathrm{~cm}^{-1}$, and $0.26 \mathrm{~J}$ pulse $\mathrm{s}^{-1}$ at $944.2 \mathrm{~cm}^{-1}$ and $933.0 \mathrm{~cm}^{-1}$. The pulse-to-pulse variation was $\pm 15 \%$ at $1027.4 \mathrm{~cm}^{-1}$ and $\pm 5 \%$ at the other two lines. The pulsed laser beam was attenuated by a $10-\mathrm{cm}$ cell filled with $0-10$ torr of $\mathrm{SF}_{6}$ or $\mathrm{SiF}_{4}$ depending on the wavelength used. The laser beam was unfocused. Around $10 \%$ of the laser energy was directed into a power meter (Laser Precision, Model RJ7200) for monitoring the laser energy continually during the pyrolysis. The incident laser energy (IO) was measured with no pyrolysis cell in the beam path.

For MPD, a BaF2 lens with a $6.0-\mathrm{cm}$ focal length was placed before the pyrolysis cell and no pinhole or attenuation cell was used. The laser beam was focused in the center of the pyrolysis cell. The $\mathrm{P}(20)$ line at $944.2 \mathrm{~cm}^{-1}$ was used with a square beam of 1.6 $\mathrm{cm}$ and an energy of $1.6 \mathrm{~J}$ pulse $\mathrm{e}^{-1}$. The energy density at the focal point was not evalu- 


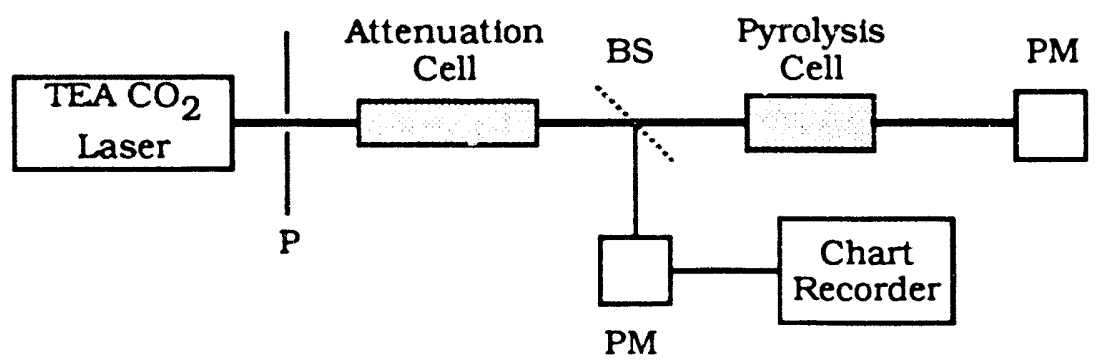

Figure 3. Schematic diagram of the experimental arrangement for the sensitized pulsed laser-induced pyrolysis $(P=$ pinhole, $B S=$ beam splitter, $\mathrm{PM}=$ power meter)

ated. The pulsed laser was operated at $0.4 \mathrm{~Hz}$ for all experiments. Higher repetition rates produce poor pulse-to pulse reproducibllity.

The $\mathrm{cw}$ laser sensitized pyrolysis was performed with a Molectron C250 grating-tuned $\mathrm{CO}_{2}$ laser. The experimental setup was similar to the pulsed laser sensitized pyrolysis shown in Figure 3, except that no attenuation cell was used. The laser power was controlled directly by the laser operating current. The laser beam was near Gaussian in profile with power levels stable to $\pm 1 \%$ throughout the experiment. The maximum power obtained was $18 \mathrm{~W}$ at $933.0 \mathrm{~cm}^{-1}, 21 \mathrm{~W}$ at $944.2 \mathrm{~cm}^{-1}$ and $5 \mathrm{~W}$ at $1027.4 \mathrm{~cm}^{-1}$. The laser power was measured by a power meter (Coherent, $1 \mathrm{~W}=1 \mathrm{mV}$ ).

For both the pulsed and cw lasers, the wavelength was calibrated by a spectrum analyzer (Optical Engineering). The transmission wus about $20-40 \%$ in a $4-\times 3.8-\mathrm{cm}$ (id) cell with 6.0 torr of SF6. Higher laser powers resulted in a greater fraction of the light transmitted. A chart recorder (Fisher 5000) was used to monitor the laser power throughout the experiment.

Several Pyrex sample cells fitted with $\mathrm{KBr}$ windows at normal incidence were used as the pyrolysis cell. MPD experiments were carried out in a 10- $\times 2-\mathrm{cm}$ (Id), $4-\mathrm{x}$ $3.8-\mathrm{cm}$ (id), or $4-x 3.5-\mathrm{cm}$ (Id) cell. The windows were attached with a $5-\mathrm{min}$ epoxy 
(Devcon). A 2.8-cm (id) Pyrex cell with an adjustable length of 1,2 , or $4 \mathrm{~cm}$ was used to study the surface effects. All the cells were fitted with two stopcocks and two O-ring joints, one connected to a $2-\mathbf{x} 0.2-\mathrm{cm}$ (Id) glass sampling tube and the other connected to the vacuum line. In the kinetic study with cyclopropane, the sampling tube was $3 \mathrm{x}$ $0.7 \mathrm{~cm}(\mathrm{Id})$ and fitted with a gas-sampling septum.

A dye laser (Spectra-Physics, Model 380) pumped by an argon lon laser was used for $\mathrm{I}_{2}$ excitation at $576.601 \mathrm{~nm}$. The wavelength was monitored by a wavemeter (Burleigh). The $\mathrm{I}_{2}$ absorption was confirmed by the strong reddish fluorescence from a second (low pressure) I2 cell that was placed in the laser path during irradiation.

In the UV photolysis experiments, HI was excited by an excimer laser (Lambda Physik) at $308 \mathrm{~nm}$. The laser beam was focused with a BaF2 lens (focal length $=15 \mathrm{~cm}$ ). For both $\mathrm{HI}$ and $\mathrm{I}_{2}$ photolysis experiments, the $4-\mathrm{x} 3.8-\mathrm{cm}$ (id) cell with two quartz windows was used.

Flash vacuum pyrolysis Flash vacuum pyrolysis (FVP) was performed on the previously described apparatus. 27

Flow pyrolysis A flow apparatus (Figure 2) was designed to fit the commercially available pyrolysis apparatus ${ }^{27}$ in place of the usual sample head. The flow apparatus has two parts: a sample chamber and a flow control assembly. The sample chamber consists of a 12-L Pyrex glassblowers' flask (Ace 6870-24) fitted with a Pyrex to stainless steel ISO size NW 40 vacuum adapter (VWR AC50900NW040). Attached to the side of the flask are two $90^{\circ}$ Teflon needle valve stopcocks (Ace 8193-04) with 14/20 inner joints. One of the stopcocks functions as a gas inlet, the other as a sample inlet. The entire assembly was enclosed in a wooden box with clear Lexan sides.

The flow control assembly was constructed with stainless steel parts and consists of a Bourdon type pressure/vacuum gauge (Omega PGS-25B-30V/15) connected to 
switchable bypass or flow control lines between two three-way ball valves (Witey SS-43XS4). The flow control line consists of a needle valve (Nupro SS-SS4) connected to a flow meter (Air Products E21-A-41504 with flow tube E29-M-150MM3). All connections are with $\frac{1}{4}$ " tubing and compression fittings (Swagelok). The pressure/vacuum gauge, three-way ball valves, needle valve and flow meter were mounted on a stainless steel panel.

The flow control assembly is connected to the sample chamber with $\frac{1}{4}$ " stainless steel tubing, a $\frac{1}{4}$ " Swagelok to $\frac{1}{4}$ " NPT fitting and a $\frac{1}{4}$ " NPT to ISO size NW 40 vacuum adapter (VWR 55009-155). The connection from the flow control assembly to the pyrolysis apparatus is identical to the one with the sample chamber except for the addition of a Pyrex to stainless steel ISO size NW 40 vacuum adapter (VWR AC50900NW040) fitted with a Pyrex $40 / 35$ outer joint.

\section{Methods and materials}

Capillary gas chromatographic analysis of condensable pyrolysis products was performed using a Hewlett-Packard HP5840A gas chromatograph equipped with a 30-m (0.25- $\mu \mathrm{m}$ film thickness) DB-1701 capllary column ( $\mathrm{N} \& \mathrm{~W}$ Scientific) using nitrogen carrier gas and flame ionization detector. GCMS analysis was performed on a Finnegan 4000 mass spectrometer. $\mathrm{H}_{2}, \mathrm{HD}$, and $\mathrm{D}_{2}$ isotopic analysis was performed on a Kratos MS50 mass spectrometer. HPLC was done on an ISCO Model 2350 instrument equipped with a Model 2360 Gradient Programmer and a Spectra-Physics SP4270 integrator using a semiprep $C_{18}$ reversed-phase column $(25 \mathrm{~cm}, 10 \mathrm{~mm}$ diameter, $5 \mu \mathrm{m}$ particle size). ${ }^{1}$ H NMR spectra were recorded on a Nicolet NT-300 spectrometer. Chemical shifts are reported in $\mathrm{ppm}(\delta)$ relative to tetramethylsilane. All materials were commercially avallable and used as recetved, except as indicated below. 
Tetralin (1) purified by the method of Bass. ${ }^{26}$ As an alternate purification, 1 was washed with $\mathrm{H}_{2} \mathrm{SO}_{4}$ until the acid layer was no longer colored and was successively washed with deionized $\mathrm{H}_{2} \mathrm{O}, 10 \% \mathrm{Na}_{2} \mathrm{CO}_{3}$ and delonized $\mathrm{H}_{2} \mathrm{O}$ and then dried with $\mathrm{MgSO}_{4}$. Finally, 1 was fractionally distilled from $\mathrm{CaH}_{2}$.

Sulfuric acid washed 1 was purified by HPLC in small portions as needed. $250 \mu \mathrm{L}$ of a $25 \% \mathrm{w} / \mathrm{v}$ solution of 1 in HPLC grade $\mathrm{CH}_{3} \mathrm{OH}$ was injected and a solvent of $90 \%$ $\mathrm{CH}_{3} \mathrm{OH}$ and $10 \% \mathrm{H}_{2} \mathrm{O}$ with a flow rate of $3.0 \mathrm{~mL} \mathrm{~min}^{-1}$ was used. Fractions were collected with the UV detector at $254 \mathrm{~nm}$. The combined fractions were diluted with saturated $\mathrm{NaCl}$ solution ( $c a \cdot \frac{1}{2}$ total volume) and deionized $\mathrm{H}_{2} \mathrm{O}$ (ca. $\frac{1}{2}$ total volume) and extracted with fractionally distllled certified grade hexanes. The combined hexanes fractions were washed with deionized $\mathrm{H}_{2} \mathrm{O}$, dried with $\mathrm{MgSO}_{4}$ and the solvent was removed in vacuo. HPLC purffied 1 was stored under Ar at $-40^{\circ} \mathrm{C}$ until use. Concentrated samples (50 $\mathrm{mg} \mathrm{mL}^{-1}$ ) analyzed by GC indicate the purity of the sample exceeds $99.8 \%$.

1,2-Dihydronaphthalene (2) was purified by HPLC as described for 1.

Benzocyclobutene (3) Benzocyclobutene (3) was prepared by FVP27 of

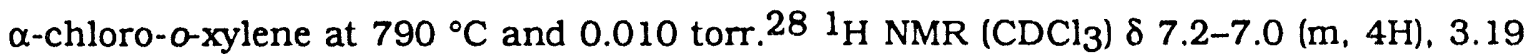
(s, $4 \mathrm{H})\left[\right.$ lit. $5 \mathrm{~b} 1_{\mathrm{H} \mathrm{NMR}}\left(\mathrm{CDCl}_{3}\right) \delta 7.01(\mathrm{~m}, 4 \mathrm{H}), 3.11$ (s, $\left.4 \mathrm{H}\right)$ ); GCMS $(70 \mathrm{eV}) \mathrm{m} / e(\%$ base peak) 104 (100), 103 (54.0), 78 (49.6), 51 (39.1) [lit.5b MS (50 eV) m/e (\% base peak) 104 (100), 103 (53), 78 (59), 51 (52)].

o-Allyltoluene (4) o-Allyltoluene (4) was prepared by the previously published procedure ${ }^{29}$ and was purified by HPLC as described for $1 .{ }^{1} \mathrm{H} \mathrm{NMR}_{\left(\mathrm{CDCl}_{3}\right)} \delta$ $7.12(\mathrm{~s}, 4 \mathrm{H}), 5.94\left(\mathrm{qt}, J_{\mathrm{q}}=10.3 \mathrm{~Hz}, J_{\mathrm{t}}=6.4 \mathrm{~Hz}, 1 \mathrm{H}\right.$ ), 5.04 (dq, $J_{\mathrm{d}}=10.1 \mathrm{~Hz}, J_{\mathrm{q}}=1.6 \mathrm{~Hz}, 1$ $\mathrm{H}), 4.98\left(\mathrm{dq}, J_{\mathrm{d}}=17.0 \mathrm{~Hz}, J_{\mathrm{q}}=1.7 \mathrm{~Hz}, 1 \mathrm{H}\right), 3.36\left(\mathrm{dt}, J_{\mathrm{d}}=6.3 \mathrm{~Hz}, J_{\mathrm{t}}=1.6 \mathrm{~Hz}, 1 \mathrm{H}\right), 2.28$ $(\mathrm{s}, 3 \mathrm{H})\left[1 \mathrm{lit} .5 \mathrm{~b} 1_{\mathrm{H} \mathrm{NMR}}\left(\mathrm{CCl}_{4}\right) \delta 6.94(\mathrm{~s}, 4 \mathrm{H}), 5.79\right.$ (qt, $\left.J_{\mathrm{q}}=11.3 \mathrm{~Hz}, J_{\mathrm{t}}=6.5 \mathrm{~Hz}, 1 \mathrm{H}\right), 4.93$ $(\mathrm{m}, 1 \mathrm{H}), 4.79\left(\mathrm{dq}, J_{\mathrm{d}}=11.3 \mathrm{~Hz}, J_{\mathrm{q}}=2.1 \mathrm{~Hz}, 1 \mathrm{H}\right), 3.24\left(\mathrm{dt}, J_{\mathrm{d}}=6.0 \mathrm{~Hz}, J_{\mathrm{t}}=1.8 \mathrm{~Hz}, 2 \mathrm{H}\right)$, 
2.20 (s, 3H)]; GCMS (70 eV) m/e (\% base peak) 132 (77.5), 117 (100), 115 (42.3), 91 (35.6), 65 (31.6) [lit. $5 \mathrm{~b}$ MS $(50 \mathrm{eV}) \mathrm{m} / e 132$ (parent), 117 (base)].

2-Methyl-1H-indene 2-Methyl-1H-indene was synthesized using the literature preparation. $30 \mathrm{l}_{\mathrm{H} \text { NMR }\left(\mathrm{CDCl}_{3}\right)} \delta 7.38-7.04(\mathrm{~m}, 4 \mathrm{H}), 6.47(\mathrm{~s}, 1 \mathrm{H}), 3.29(\mathrm{~s}, 2 \mathrm{H}), 2.18$ (s, $3 \mathrm{H}$ ) [lit. $311^{1} \mathrm{H} \mathrm{NMR}_{\left(\mathrm{CDCl}_{3}\right)} \delta 7.11-7.05(\mathrm{~m}, 4 \mathrm{H}), 6.50$ (s, $\left.1 \mathrm{H}\right), 3.30$ (s, $\left.2 \mathrm{H}\right), 2.18$ (s, 3 H)]: GCMS (70 eV) m/e (\% base peak) $130(100), 129(61.1), 128(30.1), 115$ (76.1) [lit. 30 MS (70 eV) m/e (\% base peak) $130(100), 115(70))$.

2-Methyllndan (7) 2-Methylindan was prepared according to the literature. $30{ }^{1} \mathrm{H} \mathrm{NMR}_{\left(\mathrm{CDCl}_{3}\right)}$ 8 7.27-7.05 (m, $\left.4 \mathrm{H}\right), 3.10-2.97(\mathrm{~m}, 2 \mathrm{H}), 2.58-2.47(\mathrm{~m}, 3 \mathrm{H}), 1.14$ (d. $J=6.2 \mathrm{~Hz}, 3 \mathrm{H})\left[11 \mathrm{t} .301_{\mathrm{H} \mathrm{NMR}}\left(\mathrm{CDCl}_{3}\right) \delta 7.24-7.04(\mathrm{~m}, 4 \mathrm{H}), 3.12-2.92(\mathrm{~m}, 2 \mathrm{H}), 2.60\right.$ $2.40(\mathrm{~m}, 3 \mathrm{H}), 1.13(\mathrm{~d}, J=6 \mathrm{~Hz}, 3 \mathrm{H})$ ): GCMS $(70 \mathrm{eV}) \mathrm{m} / e(\%$ base peak) $132(63.8), 117$ (100), 115 (30.8) [lit. $32 \mathrm{MS}(70 \mathrm{eV}) \mathrm{m} / \mathrm{e} 132$ (parent), 117 (base)].

3-Methyl-1H-indene 3-Methyl-1H-indene was prepared according to the literature procedure. ${ }^{30} 1_{\mathrm{H} ~ N M R}\left(\mathrm{CDCl}_{3}\right) \delta 7.49-7.17(\mathrm{~m}, 4 \mathrm{H}), 6.21-6.18(\mathrm{~m}, 1 \mathrm{H}), 3.33-$ $3.29(\mathrm{~m}, 2 \mathrm{H}), 2.18-2.15(\mathrm{~m}, 3 \mathrm{H})\left[1 \mathrm{it} .301_{\mathrm{H} \mathrm{NMR}}\left(\mathrm{CDCl}_{3}\right) \delta 7.45-7.05(\mathrm{~m}, 4 \mathrm{H}), 6.18(\mathrm{~s}, 1\right.$ H), 3.30 (s, $2 \mathrm{H}$ ), 2.18 (s, $3 \mathrm{H})$ ]; GCMS (70 eV) m/e (\% base peak) $130(100), 129$ (75.6), 128 (43.5), 115 (76.7) [1it. 30 MS (70 eV) m/e (\% base peak) 130 (34), 115 (64), 77 (41)].

1-Methylindan 1-Methylindan was prepared according to the previously published procedure. $301_{\mathrm{H} \mathrm{NMR}}\left(\mathrm{CDCl}_{3}\right) \delta$ 7.24-7.10 (m, $\left.4 \mathrm{H}\right), 3.25-3.10(\mathrm{~m}, 1 \mathrm{H}), 2.97-$ $2.75(\mathrm{~m}, 2 \mathrm{H}), 2.36-2.23(\mathrm{~m}, 1 \mathrm{H}), 1.67-1.52(\mathrm{~m}, 1 \mathrm{H}), 1,29(\mathrm{~d}, J=6.6,3 \mathrm{H})[1 \mathrm{it} .3 \mathrm{C}){ }^{1} \mathrm{H} \mathrm{NMR}$ $\left(\mathrm{CDCl}_{3}\right) \delta 7.32-7.08(\mathrm{~m}, 4 \mathrm{H}), 3.28-2.78(\mathrm{~m}, 3 \mathrm{H}), 2.40-1.52(\mathrm{~m}, 2 \mathrm{H}), 1.28(\mathrm{~d}, J=7 \mathrm{~Hz}, 3$ H)]: GCMS (70 eV) m/e (\% base peak) $132(27.8), 117$ (100), 115 (19.1) [lit. ${ }^{33} \mathrm{MS}$ (70 eV) m/e (\% base peak) 132 (24), 131 (11), 128 (5), 117 (100), 115 (24), 91 (13), 77 (7), 65 (8), 63 (9)]. 
Laser-Induced pyrolysis 6 Samples were prepared in a turbomolecular pump (Pfeiffer, TPU 40) vacuum system, with grease-free stopcocks and O-ring joint connections. The base pressure was less than $10^{-6}$ torr. The pyrolysis cell and the vacuum manifold were heated by a heat gun to clean the walls before the sample was prepared. Pressure was measured by a manometer (MKS 221 AHS-F) with 10-torr full scale. The sample preparation was the same in both $\mathrm{cw}$ and pulsed laser sensitized pyrolyses. Initially, freshly purified 1, stored in a side arm of the vacuum manifold, was frozen with liruid $\mathrm{N}_{2}$ and the air was evacuated. Sensitizer was then expanded into the sample cell and was frozen into the sample tube. Next, the stopcock to the sample tube was closed and the cell was evacuated. Then 1 was allowed to expand into the cell untll the pressure was 0.325 torr. The sensitizer was then warmed up to expand back into the cell as the stopcock was opened. Five minutes was allowed for equilibration of the gases before irradiation. When an additional gas was required for the sample mixtures, it was usually introduced after the sensitizer and was condensed in the sample tube before 1 was introduced. For MPD experiments, the cell contains only 0.325 torr of 1 .

The pyrolysis cell was irradiated immediately after sample preparation. The reaction time was 1-2 $\mathrm{h}$ for a pulsed laser experiment and 1-5 min for a $\mathrm{cw}$ laser experiment. After the reaction, the condensable materials were frozen into the sample tube. Then the sample tube was warmed up with a Dry Ice/2-propanol bath and the sensitizer was evacuated. The tube was then detached from the cell. $50 \mu \mathrm{L}$ of hexanes (HPLC grade) with biphenyl added as an internal standard was introduced along the wall with a $50-\mu \mathrm{L}$ syringe (Hamilton). GC analysis was done immediately. The non-condensable gas mixtures were taken to a mass spectrometer for $\mathrm{H}_{2}, \mathrm{HD}$, and $\mathrm{D}_{2}$ analysis in a continuous flow system, as needed. 
After the experiment was complete, the pyrolysis cell was cleaned with $\mathrm{HNO}_{3}$, $\mathrm{H}_{2} \mathrm{O}$ and acetone. Following the $\mathrm{I}_{2}, \mathrm{HI}$, or deuterium experiments, the $\mathrm{KBr}$ windows were repolished.

The infrared spectra of 1 and $\mathrm{SF}_{6}$ for the laser experiments were taken by FTIR with $0.3 \mathrm{~cm}^{-1}$ resolution with a $4-\mathrm{x} 3.8-\mathrm{cm}$ (id) cell. Both $1\left(0.325\right.$ torr) and $\mathrm{SF}_{6}(6.0$ torr) were at the same pressure as in the pyrolysis experiment.

Flash vacuum pyrolysis The pyrolysis oven was equllibrated the desired temperature before pyrolysis. A weighed sample (ca. 10-25 mg) was placed in a $50-\mathrm{mL}$ 24/40 round-bottom flask and connected to the pyrolysis apparatus fitted with a right angle sample adapter (40/35 outer $90^{\circ}$ to $24 / 40$ inner). The entire system was flushed with $\mathrm{N}_{2}$ and the sample frozen with liquid $\mathrm{N}_{2}$. The system was evacuated with the roughing pump to ca. 0.1 torr and the pyrolysis trap was frozen with liquid $\mathrm{N}_{2}$. If the diffusion pump was used, the system was then evacuated to $10^{-5}$ torr. The sample was warmed to the desired temperature with an appropriate bath. A sample temperature of 0 ${ }^{\circ} \mathrm{C}$ was maintained with an ice/water bath for all pyrolysis experiments except for those at $-30{ }^{\circ} \mathrm{C}\left(\mathrm{Dry}\right.$ Ice $/ \mathrm{CaCl}_{2} / \mathrm{H}_{2} \mathrm{O}$ ) and room temperature (water). After the pyrolysis was complete, the system was filled with $\mathrm{N}_{2}$ and the trap was allowed to warm to near room temperature. $1.0 \mathrm{~mL}$ of $c a .2 \mathrm{mg} \mathrm{mL}-1$ solution of biphenyl in $\mathrm{CH}_{2} \mathrm{Cl}_{2}$ and an additional $1.0 \mathrm{~mL}$ of $\mathrm{CH}_{2} \mathrm{Cl}_{2}$ was added to the trap. The trap was thoroughly rinsed with the solution, which was immediately analyzed by GC.

Flow pyrolysis The flow pyrolysis apparatus (Figure 2) was filled with Ar and evacuated several times and then allowed to pump down at least $12 \mathrm{~h}$ (flow assembly on bypass). A weighed sample in a 5-mL 14/20 round-bottom flask flushed with Ar was attached to the sample inlet, frozen with liquid $\mathrm{N}_{2}$ and the sample inlet was opened. After the system had returned to the original pressure $(30-60 \mathrm{~min})$, the sample inlet was 
closed and the sample allowed to warm to room temperature. The sample was refrozen with liquid $\mathrm{N}_{2}$ and opened to the system for an additional 15-30 min. The sample chamber was isolated from the flow assembly and pyrolysis apparatus. The sample inlet was opened and the sample was allowed to warm to room temperature. No liquid sample remained in the flask. The sample chamber was filled with Ar to atmospheric pressure through the gas inlet and the gas mixture was allowed to equilibrate for $15 \mathrm{~min}$. The pyrolysis trap was cooled with liquid $\mathrm{N}_{2}$. The flow of gas mixture into the pyrolysis apparatus was maintained at a fixed rate of $20-25 \mathrm{~mL} \mathrm{~min}^{-1}(\mathrm{Ar} / 1 \mathrm{~atm})$ until the sample chamber was evacuated to ca. $\frac{1}{2}$ atmospheric pressure. The sample chamber and flow control assembly were isolated from the pyrolysis apparatus that was then filled with $\mathrm{N}_{2}$. After the trap had warmed to near room temperature, $0.5 \mathrm{~mL}$ blphenyl in $\mathrm{CH}_{2} \mathrm{Cl}_{2}$ (ca. $2 \mathrm{mg} \mathrm{mL}^{-1}$ ) and an additional $0.5 \mathrm{~mL} \mathrm{CH}_{2} \mathrm{Cl}_{2}$ was added to the trap. The trap was thoroughly rinsed with the solution, which was immediately analyzed by GC. A clean trap was fitted to the pyrolysis apparatus and the entire assembly was filled with Ar and evacuated several times. The apparatus was allowed to pump down at least $12 \mathrm{~h}$ (flow assembly on bypass) before repeat use.

Product analysis The oven for capillary GC was initially programmed at 80 ${ }^{\circ} \mathrm{C}$ for $10 \mathrm{~min}$, heated at $3{ }^{\circ} \mathrm{C} \mathrm{min}-1$ until the temperature reached $242{ }^{\circ} \mathrm{C}$ and held for 1 min. For the laser-induced decomposition samples, the oven was initially programmed at $80{ }^{\circ} \mathrm{C}$ for $10 \mathrm{~min}$, heated at $3{ }^{\circ} \mathrm{C} \mathrm{min}^{-1}$ for $15 \mathrm{~min}$ and then $15^{\circ} \mathrm{C} \mathrm{min}^{-1}$ until the temperature reached $250^{\circ} \mathrm{C}$. All compounds eluted before $35 \mathrm{~min}$.

For the FVP and flow pyrolysis samples, $1 \mu \mathrm{L}$ of $\mathrm{CH}_{2} \mathrm{Cl}_{2}$ solution was injected while $2 \mu \mathrm{L}$ of a hexanes solution was used to analyze the laser-induced decomposition samples. Results agreed among injections within $\pm 3 \%$. For FVP and flow pyrolysis experiments, the major products $(1,2,3,4,5,6,8$, toluene, ethylbenzene, o-xylene, and 
o-ethyltoluene) were corrected for fid response to a known amount of added standard (biphenyl). Percentages reported are for moles of product relative to total moles of recovered material. In the laser experiments, the major products $(2,3,4,6,6$, and 8 ) were corrected for fid response relative to 1 . Conversion was calculated from a known amount of added standard (biphenyl). Percentages reported are for moles of product relative to total moles of products. The reproducibility for the overall experiment was within $\pm 5 \%$. Major products were identified by GC retention time of authentic samples $(1,2,3,4,5,6,7,8$, toluene, ethylbenzene, o-xylene, o-ethyltoluene, 1-methylindan, 2-methyl-1 $\mathrm{H}$-indene, and 3-methyl-1 $\mathrm{H}$-indene) and GCMS. The molecular weight of minor products was determined by GCMS.

Isotopic analyses for laser studies were done by GCMS. The responses of $\mathrm{H}_{2}$ and $D_{2}$ were almost the same in a 1 to $1 \mathrm{H}_{2}: \mathrm{D}_{2}$ mixture. $\mathrm{HD}$ was assumed to produce the same response. 


\section{REFERENCES}

(1) Schlupp, K. F.: Wlen, H. Angew. Chem., Int. Ed. Engl. 1876, 15, 341.

(2) Whitehurst, D. D. "Organic Chemistry of Coal," In ACS Symposium Series 71. Larson, J. W., Ed.: American Chemical Society: Washington, D. C., 1978; pp $1-35$.

(3) Poutsma. M. L. A Review of Thermolysis Studies of Model Compounds Relevant to Processing of Coali ORNL/TM-10673, Oak Ridge National Laboratory, Oak Ridge. TN 37831. This review is avallable from National Technical Information Service, U. S. Dept. of Commerce, 5285 Port Royal Rd., Springfield, VA 22161.

(4) (a) Badger, G. M.: KImber, R. W. L. J. Chem. Soc. 1960, 266. (b) Badger, G. M.; Kimber, R. W. L.; Novotny, J. Aust. J. Chem. 1962, 15, 616. (c) Loudon, A. G.; Maccoll. A.; Wong, S. K. J. Chem. Soc. B 1970, 1733. (d) Penninger, J. M. L.: Slotboom, H. W. Recl. Trav. Chim. Pays-bays 1973, 92, 513. (e) Penninger, J. M. L.: Slotboom, H. W. Ibid. 1973, 92, 1089. (f) Tominaga, H.; Yahag1, U. J. Fac. Eng., Uniw. Tokyo, Ser. A 1977, 15, 68. (g) Bredael, P.; Vinh, T. H. Fuel 1979, 58, 211. (h) Gangwer, T.; MacKenzie, D.: Casano, S. J. Phys. Chem. 1979, 83, 2013. (1) Cyprès, R.; Bredael, P. Fuel Process. Tech. 1980, 3, 297. (1) Trushkova, L. V.: Magarll, R. Z.: Korzun, N. V.: Bulatov, R. A. Russ. J. Phys. Chem. 1980. 54, 1062. (k) Takahash1, K.: Ogino, Y. Fuel 1981, 60, 975. (1) Trahanovsky, W. S.; Swenson, K. E. J. Org. Chem. 1981, 46, 2984. (m) Bajus, M.: Baxa, J. Coll. Czech. Chem. Commun. 1982, 47, 1838. (n) Penninger, J. M. L. Int. J. Chem. Kinetics 1982, 14. 761. (o) Hillebrand, W.; Hodek, W.; Kölling, G. Fuel 1984, 63, 756. (p) Korzun, N. V.: Trushkova, L. V. Kinetics Catal 1985, 26, 195.

(5) (a) Berman, M. R.; Comita, P. B.; Moore, C. B.; Bergman, R. G. J. Amer. Chem. Soc. 1980, 102, 5692. (b) Comita, P. B.; Berman, M. R.; Moore, B. C.: Bergman, R. G. J. Phys. Chem. 1981, 85, 3266.

(6) Zhu, J. Ph.D. Dissertation, Iowa State University of Science and Technology, 1989.

(7) Tsang, W.; Cul, J. P. J. Amer. Chem. Soc. 1990, 112, 1665.

(8) In the liquid-phase pyrolysis of 1 , the major ring-contracted product has been identified as 1-methylindan, 9 but we have conclusively identified the major methylindan in gas-phase pyrolysis of 1 as the 2-methyl isomer (7). Some 
workers have incorrectly reported 1 -methylından as the gas-phase pyrolysis product. 4 d,e,n

(9) Benjamin, B. M.: Hagaman, E. W.: Raaen, V. F.: Collins, C. J. Fuel 1979, 58. 386.

(10) (a) Rosenfleld, R. N.; Brauman, J. I.; Barker, J. R.; Golden, D. M. J. Amer. Chem. Soc. 1977, 99, 8063. (b) Danen, W. C.; Koster, D. F.; Zitter, R. N. J. Amer. Chem. Soc. 1979, 101, 4281. (c) Relser, C.: Lussier, F. M.; Jensen, C.; Steinfield, J. I. J. Amer. Chem. Soc. 1979, 101, 350. (d) Golden, D. M.; Rossi, M. J.; Baldwin, A. C.: Barker. J. R. Acc. Chem. Res. 1981, 14, 56.

(11) (a) Shaub, W. M.; Bauer, S. H. Int. J. Chem. Kinetics 1975, 7, 509. (b) Dal. H. L.; Specht, E.: Berman, M. R.: Moore, C. B. J. Chem. Phys. 1982, 77, 4494. (c) McMllen, D. F.; Lewis, K. E.; Smith, G. P.; Golden, D. M. J. Phys. Chem. 1982. 86, 709.

(12) Zhu, J.: Yeung, E. S. J. Phys. Chem. 1988, 92, 2184.

(13) Tsang. W. Int. J. Chem. Kinet. 1978, 10, 1119.

(14) Yappert, M. C.: Yeung, E. S. J. Amer. Chem. Soc. 1986, 108, 7529.

(15) The intensity profile here is tophat shape with variations of $30 \%$ across the beam. compared to a near Gaussian beam in the previous work. ${ }^{5}$ A $6-\mathrm{cm}$ focal length $\mathrm{BaF}_{2}$ lens was used in these experiments, while a $15-\mathrm{cm}$ focal length $\mathrm{NaCl}$ lens was used previously. The laser pulse here has a $150-n s$ peak and $2-\mu$ s tail, compared to a $100-n s$ peak and $1-\mu$ s tall in previous work.

(16) The cw laser beam is near Gaussian in proflle with power levels stable to $\pm 1 \%$ throughout the experiment, compared to $\pm 5 \%$ pulse-to-pulse variations in the $\mathrm{P}(20) \mathrm{CO}_{2}$ line (MPD and $\mathrm{SF}_{6}$ sensitization) and $\pm 15 \%$ pulse-to-pulse variations in the $\mathrm{P}(40) \mathrm{CO}_{2}$ line ( $\mathrm{SiF}_{4}$ sensitization).

(17) Benson, S. W. Thermochemical Kinetics, 2nd ed.; Wiley: 1976.

(18) (a) Gill, G. B.; Hawkins, S. J. Chem. Soc., Chem. Commun. 1974, 742. (b) Heesing, A.: Müllers, W. Chem. Ber. 1980, 113, 9. (c) King. H-H.: Stock, L. M. Fuel 1981. 60, 748. (d) Allen, D. T.; Gavalas, G. R. J. Chem. Kinetics 1983, 15, 219. (e) Franz, J. A.; Camaioni, D. M.; Belshline, R. R.; Dalling. D. K J. Org. Chem. 1984, 49. 3563. 
(19) Billmers, R.; Griffth, L. L.; Stein, S. E. J. Phys. Chem. 1986, 90, 517.

(20) Robaugh, D.: Tsang, W. J. Phys. Chem. 1886, 90, 4159.

(21) Malandra, J. L.; Trahanovsky, W. S. J. Org. Chem. 1993, 58, 0000. [Paper 3, this dissertation]

(22) Gajewskd, J. J.; Paul, G. C. J. Org. Chem. 1980. 55. 4575.

(23) Malandra, J. L.: Trahanovsky, W. S., manuscript in preparation. [Paper 2, this dissertation]

(24) (a) Chapmail, O. L.: Tsou, U. P. E. J. Amer. Chem. Soc. 1984, 106, 7974. (b) Trahanovs'ky, W. S.; Scribner, M. E. J. Amer. Chem. Soc. 1984, 106, 7976.

(25) Trahanovsky, W. S.: Malandra, J. L.: Ferguson, J. M. J. Amer. Chem. Soc. 1993. 115, 0000. [Paper 5, this dissertation]

(26) Bass, K. C. J. Chem. Soc. 1964, 3498.

(27) Trahanovsky, W. S.; Ong, C. C.; Pataky, J. G.; Weltl, F. L.; Mullen, P. W.; Clardy, J. C.: Hansen, R. S. J. Org. Chem. 1971, 36, 3575. Commercial apparatus is avallable from Kontes Scientific Glassware, Vineland, NJ 08360.

(28) Morello, M. J.; Trahanovsky, W. S. Tetrahedron Lett. 1979, 4435.

(29) Hurd, C. D.; Bollman, H. T. J. Amer. Chem. Soc. 1934, 56, 447.

(30) Adamczyk, M.: Watt, D. S.: Netzel, D. A. J. Org. Chem. 1984, 49, 4226.

(31) Banks, H.; Ziffer, H. J. Org. Chem. 1982, 47, 3743.

(32) Douboudin, J. G.; Jousseaume, B.; Pinet-Vallier, M. J. Organomet. Chem. 1979. $172,1$.

(33) Finkel'shtein, E. S.; Mikaya, A. I.; Zaikin, V. G.; Vdovin, V. M. Neftekhimiva 1980. 20, 75; Petrol. Chem. USSR 1980, $20,6$. 
APPENDIX 1

\section{SUPPLEMENTARY DATA TABLES}

Table A-I. Products and recovered starting material, total recovery of material, and conversion from the FVP of tetralin (1) at $10^{-5}$ torr and varlous oven temperatures $a, b$

\begin{tabular}{|c|c|c|c|c|c|}
\hline \multirow[b]{2}{*}{ entry } & \multicolumn{5}{|c|}{ ydeld, $\% c$} \\
\hline & $\mathrm{RT}^{d}$ & $850^{\circ} \mathrm{C}$ & $900^{\circ} \mathrm{C}$ & $950^{\circ} \mathrm{C}$ & $1000^{\circ} \mathrm{C}$ \\
\hline toluene & - & - & - & 0.10 & 0.65 \\
\hline TA & - & - & - & - & $e$ \\
\hline ethylbenzene & - & - & 0.03 & 0.09 & 0.29 \\
\hline$m / p$-xylene & - & - & - & 0.02 & 0.08 \\
\hline o-xylene & - & - & 0.12 & 0.37 & 1.46 \\
\hline styrene (6) & - & 0.41 & 2.09 & 5.80 & 18.62 \\
\hline benzocyclobutene (3) & - & 1.67 & 4.52 & 7.73 & 9.40 \\
\hline allylbenzene & - & - & - & - & 0.04 \\
\hline propylbenzene & - & - & - & - & 0.04 \\
\hline o-ethyltoluene & - & - & 0.02 & 0.07 & 0.12 \\
\hline o-methylstyrene & 一 & - & 0.11 & 0.32 & 0.75 \\
\hline$m / p$-allyltoluene & - & - & - & - & 0.10 \\
\hline o-allyltoluene (4) & - & 0.47 & 1.15 & 1.66 & 1.54 \\
\hline indene (8) & - & 0.15 & 1.08 & 3.00 & 8.02 \\
\hline 2-methylindan (7) & - & 0.14 & 0.59 & 1.10 & 1.21 \\
\hline 1-methyllndan & - & - & - & 0.06 & 0.06 \\
\hline
\end{tabular}

Table A-I continues on next page 
Table A-I. Continued

\begin{tabular}{|c|c|c|c|c|c|}
\hline \multirow[b]{2}{*}{ entry } & \multicolumn{5}{|c|}{ yield. $\% c$} \\
\hline & $\mathrm{RT} d$ & $850^{\circ} \mathrm{C}$ & $900^{\circ} \mathrm{C}$ & $950^{\circ} \mathrm{C}$ & $1000^{\circ} \mathrm{C}$ \\
\hline TD- $130\left[\mathrm{C}_{10} \mathrm{H}_{10} \mathrm{O}\right.$ & - & - & 0.04 & 0.12 & 0.37 \\
\hline $\mathrm{TE}-130 \mid \mathrm{C}_{10} \mathrm{H}_{10} \mathrm{l}$ & - & - & - & 0.03 & - \\
\hline TF- $130 \mid \mathrm{C}_{10} \mathrm{H}_{10} \mathrm{O}$ & - & - & 0.04 & 0.07 & 0.07 \\
\hline$o-(1$-propenyl)toluene & - & - & 0.13 & 0.32 & 0.50 \\
\hline $\mathrm{TH}-130\left[\mathrm{C}_{10} \mathrm{H}_{10} \mathrm{l}\right.$ & - & - & 0.05 & 0.08 & 0.09 \\
\hline $\mathrm{TI}-132\left[\mathrm{C}_{10} \mathrm{H}_{12}\right]$ & - & - & - & 0.05 & 0.08 \\
\hline $\mathrm{TJ}-132\left[\mathrm{C}_{10} \mathrm{H}_{12}\right]$ & - & - & - & 0.06 & 0.09 \\
\hline tetralin (1) & 99.85 & 95.19 & 82.76 & 65.64 & 34.63 \\
\hline 2-methyl-1H-indene & - & 0.04 & 0.19 & 0.35 & 0.44 \\
\hline TK- $130\left[\mathrm{C}_{10} \mathrm{H}_{10}\right]$ & - & 0.07 & 0.28 & 0.46 & 0.51 \\
\hline 1.2-dihydronaphthalene (2) & 0.06 & 1.36 & 4.13 & 5.37 & 4.24 \\
\hline $\mathrm{TL}-128\left[\mathrm{C}_{10} \mathrm{H}_{8}\right]$ & - & - & 0.03 & 0.04 & 0.14 \\
\hline 1,4-dihydronaphthalene & 0.05 & - & - & 0.02 & - \\
\hline TM & $e$ & $e$ & $e$ & - & - \\
\hline naphthalene (5) & 0.05 & 0.51 & 2.66 & 7.04 & 16.27 \\
\hline TN & $e$ & $e$ & $e$ & $e$ & - \\
\hline TO- $148\left[\mathrm{C}_{11} \mathrm{H}_{16}\right]$ & - & - & - & 0.02 & 0.03 \\
\hline 2-methylnaphthalene & - & - & - & - & 0.09 \\
\hline 1-methylnaphthalene & - & - & - & - & 0.07 \\
\hline recovery $f$ & 92.90 & 90.02 & 85.62 & 80.37 & 76.25 \\
\hline conversion $g$ & $d$ & 4.81 & 17.24 & 34.36 & 65.37 \\
\hline
\end{tabular}

Table A-I footnote on next page 
Table A-I. Footnote

$a_{\text {FVP }}$ conditions: system pressure $=1 \times 10^{-5}$ torr, sample temperature $=0{ }^{\circ} \mathrm{C}$. ${ }^{b}$ Amounts determined by GC with a known quantity of biphenyl added as standard. Data represent the average of triplicate runs. Products identified by comparison with authentic samples or those that could be identified by retention time and GCMS are indicated by name. Products that were identified by GCMS only are indicated by code: $X Y-n n n$, where ' $X$ ' corresponds to the system studied $(T=$ pyrolysis of 1$), Y$ ' to the individual unknown product (A, B, C, etc.), and ' $n$ nn' to the nominal mass. $c$ Moles of product divided by total moles of recovered material. $d$ Starting material purity assay. $e$ Unidentified product which constitutes $\leq 0.05 \%$ total area by GC. $f_{\text {Total moles of re- }}$ covered material divided by moles of starting material used. $g$ Total moles of recovered material minus moles of recovered starting material divided by total moles of recovered material. 
Table A-n. Products and recovered starting material, total recovery of material, and conversion from the FVP of tetralin (1) at 0.10 torr and various oven temperatures $a . b . c$

\begin{tabular}{|c|c|c|c|c|}
\hline \multirow[b]{2}{*}{ entry } & \multicolumn{4}{|c|}{ yield. $\% d$} \\
\hline & $750^{\circ} \mathrm{C}$ & $800^{\circ} \mathrm{C}$ & $850^{\circ} \mathrm{C}$ & $900^{\circ} \mathrm{C}$ \\
\hline toluene & - & - & - & 0.18 \\
\hline ethylbenzene & - & - & - & 0.12 \\
\hline o-xylene & - & - & 0.07 & 0.42 \\
\hline styrene (6) & 0.06 & 0.24 & 1.71 & 7.34 \\
\hline benzocyclobutene (3) & 0.28 & 1.08 & 3.87 & 8.10 \\
\hline o-ethyltoluene & - & - & - & 0.08 \\
\hline o-methylstyrene & - & - & 0.08 & 0.34 \\
\hline butylbenzene & - & - & 0.03 & 0.05 \\
\hline o-allyltoluene (4) & 0.08 & 0.31 & 0.85 & 1.32 \\
\hline indene (8) & 0.02 & 0.10 & 0.65 & 2.45 \\
\hline 2-methylindan (7) & - & 0.12 & 0.65 & 1.24 \\
\hline 1-methylindan & - & - & - & 0.07 \\
\hline TD- $130\left[\mathrm{C}_{10} \mathrm{H}_{10} \mathrm{I}\right.$ & - & - & 0.05 & 0.13 \\
\hline $\mathrm{TF}-130\left[\mathrm{C}_{10} \mathrm{H}_{10} \mathrm{O}\right]$ & - & - & - & 0.03 \\
\hline$o$-(1-propenyl)toluene & - & - & 0.10 & 0.26 \\
\hline$T H-130\left[\mathrm{C}_{10} \mathrm{H}_{10}\right]$ & - & - & - & 0.07 \\
\hline $\mathrm{TI}-132\left[\mathrm{C}_{10} \mathrm{H}_{12}\right]$ & - & - & - & 0.03 \\
\hline $\mathrm{TJ}-132\left[\mathrm{C}_{10} \mathrm{H}_{12}\right]$ & - & - & - & 0.06 \\
\hline tetralin (1) & 98.63 & 96.31 & 85.69 & 65.73 \\
\hline 2-methyl-1H-indene & - & - & 0.33 & 0.45 \\
\hline TK- $130\left[\mathrm{C}_{10} \mathrm{H}_{10} \mathrm{O}\right.$ & - & - & 0.27 & 0.38 \\
\hline
\end{tabular}

Table A-II continues on next page 
Table A-II. Continued

\begin{tabular}{|c|c|c|c|c|}
\hline \multirow[b]{2}{*}{ entry } & \multicolumn{4}{|c|}{ yield, \% $d$} \\
\hline & $750^{\circ} \mathrm{C}$ & $800^{\circ} \mathrm{C}$ & $850^{\circ} \mathrm{C}$ & $900^{\circ} \mathrm{C}$ \\
\hline 1,2-dihydronaphthalene (2) & 0.68 & 1.44 & 3.56 & 4.73 \\
\hline $\mathrm{TL}-128\left[\mathrm{C}_{10} \mathrm{H}_{8}\right]$ & - & - & - & 0.08 \\
\hline 1,4-dihydronaphthalene & - & - & - & - \\
\hline TM & $e$ & $e$ & $e$ & - \\
\hline naphthalene (5) & 0.24 & 0.42 & 2.09 & 6.34 \\
\hline $\mathrm{TN}$ & $e$ & $e$ & - & $e$ \\
\hline recovery $f$ & 91.78 & 91.98 & 83.75 & 85.21 \\
\hline conversion $g$ & 1.37 & 3.69 & 14.31 & 34.27 \\
\hline
\end{tabular}


Table A-III. Products and recovered starting material, total recovery of material, and conversion from the FVP of tetralin (1) at $10^{-5}$ torr and various sample temperatures $a, b, c$

\begin{tabular}{|c|c|c|c|}
\hline \multirow[b]{2}{*}{ entry } & \multicolumn{3}{|c|}{ yield, $\% d$} \\
\hline & $-30^{\circ} \mathrm{C}$ & $0^{\circ} \mathrm{C}$ & $\mathrm{RT}$ \\
\hline toluene & - & 0.08 & 0.13 \\
\hline ethylbenzene & - & 0.05 & 0.10 \\
\hline$o$-xylene & - & 0.18 & 0.32 \\
\hline styrene (6) & 1.76 & 3.04 & 3.31 \\
\hline benzocyclobutene (3) & 5.30 & 5.65 & 4.20 \\
\hline o-ethyltoluene & - & - & 0.11 \\
\hline o-methylstyrene & 0.06 & 0.14 & 0.32 \\
\hline o-allyltoluene (4) & 1.40 & 1.21 & 1.10 \\
\hline indene (8) & 0.77 & 1.29 & 2.41 \\
\hline 2-methylindan (7) & 0.87 & 0.71 & 0.57 \\
\hline 1-methylindan & 0.06 & 0.05 & 0.05 \\
\hline $\mathrm{TD}-130\left[\mathrm{C}_{10} \mathrm{H}_{10} \mathrm{O}\right.$ & - & 0.05 & 0.16 \\
\hline $\mathrm{TF}-130\left[\mathrm{C}_{10} \mathrm{H}_{10} \mathrm{l}\right.$ & - & 0.03 & 0.08 \\
\hline o-(1-propenyl)toluene & 0.21 & 0.16 & 0.12 \\
\hline $\mathrm{TH}-130\left[\mathrm{C}_{10} \mathrm{H}_{10} \mathrm{l}\right.$ & - & 0.05 & 0.11 \\
\hline tetralin (1) & 86.62 & 79.29 & 69.84 \\
\hline 2-methyl-1H-indene & - & 0.34 & 0.60 \\
\hline$T K-130\left[\mathrm{C}_{10} \mathrm{H}_{10}\right]$ & 0.18 & 0.35 & 0.63 \\
\hline 1,2-dihydronaphthalene (2) & 1.69 & 4.17 & 8.98 \\
\hline$T L-128\left[\mathrm{C}_{10} \mathrm{H}_{8}\right]$ & - & - & 0.12 \\
\hline naphthalene (5) & 1.06 & 3.15 & 6.75 \\
\hline
\end{tabular}

Table A-III continues on next page 
Table A-II. Continued

\begin{tabular}{lccc}
\hline & \multicolumn{3}{c}{ yield, $\% d$} \\
\cline { 2 - 4 } entry & $-30{ }^{\circ} \mathrm{C}$ & $0{ }^{\circ} \mathrm{C}$ & RT \\
\hline recovery $e$ & 85.17 & 86.72 & 80.84 \\
conversion $f$ & 13.38 & 20.71 & 30.16 \\
\hline$a_{\text {FVP conditions: oven temperature }=900{ }^{\circ} \mathrm{C} . \text { system pressure }=1 \times 10^{-5} \text { torr. }{ }^{b} \text { See }}$ \\
Table A-I, footnote $b .{ }^{c}$ See Table A-II, footnote $c .{ }^{d}$ See Table A-I, footnote $c .{ }^{e}$ See \\
Table A-I, footnote $f . f_{\text {See Table A-I, footnote } g .}$
\end{tabular}


Table A-IV. Products and recovered starting material, total recovery of material, and conversion from the flow pyrolysis of tetralin (1) at various oven temperatures $a, b, c$

\begin{tabular}{|c|c|c|c|c|}
\hline \multirow[b]{2}{*}{ entry } & \multicolumn{4}{|c|}{ yield, $\% d$} \\
\hline & $805^{\circ} \mathrm{C}$ & $853^{\circ} \mathrm{C}$ & $905^{\circ} \mathrm{C}$ & $952^{\circ} \mathrm{C}$ \\
\hline toluene & - & - & - & 0.12 \\
\hline ethylbenzene & - & - & - & 0.13 \\
\hline o-xylene & - & - & - & 0.24 \\
\hline styrene (6) & 0.02 & 1.07 & 4.64 & 20.66 \\
\hline benzocyclobutene (3) & 0.89 & 4.73 & 9.92 & 13.94 \\
\hline o-methylstyrene & - & - & - & 0.17 \\
\hline o-allyltoluene (4) & 0.23 & 1.07 & 1.92 & 2.21 \\
\hline indene $(8)$ & - & 0.21 & 1.02 & 4.32 \\
\hline 2-methylindan (7) & - & 0.60 & 1.69 & 2.86 \\
\hline $\mathrm{TD}-130\left[\mathrm{C}_{10} \mathrm{H}_{10} \mathrm{O}\right.$ & - & - & - & 0.52 \\
\hline$o-(1-$ propenyl)toluene & - & - & 0.34 & 0.95 \\
\hline $\mathrm{TJ}-132\left[\mathrm{C}_{10} \mathrm{H}_{12}\right]$ & - & - & - & 0.14 \\
\hline 3-methyl-1H-indene & - & - & - & 0.32 \\
\hline tetralin (1) & 98.49 & 90.70 & 77.34 & 46.08 \\
\hline 2-methyl-1H-indene & - & 一 & - & 0.19 \\
\hline 1,2-dihydronaphthalene (2) & 0.36 & 1.11 & 1.74 & 2.18 \\
\hline naphthalene (5) & - & 0.52 & 1.40 & 4.97 \\
\hline recovery $e$ & 88.96 & 89.18 & 93.44 & 85.31 \\
\hline conversion $f$ & 1.51 & 9.30 & 22.66 & 53.92 \\
\hline
\end{tabular}

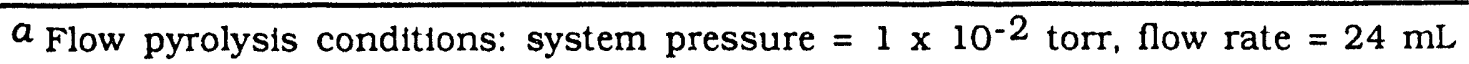
$\mathrm{min}^{-1}$ (Ar), residence time $=0.31 \mathrm{~s}$. ${ }^{b}$ See Table A-I, footnote $b$. Data at $850{ }^{\circ} \mathrm{C}$ represent the average of six runs. ${ }^{c}$ See Table A-II, footnote $c .{ }^{d}$ See Table A-I, footnote c. $e$ See Table A-I, footnote $f . f$ See Table A-I, footnote $g$. 
Table A-v. Products and recovered starting material, total recovery of material, and conversion from the flow pyrolysis of o-allyltoluene (4) at various oven temperatures $a, b$

\begin{tabular}{|c|c|c|c|c|c|c|c|}
\hline \multirow[b]{2}{*}{ entry } & \multicolumn{7}{|c|}{ yield, \% $c$} \\
\hline & $\mathrm{RT} d$ & $700^{\circ} \mathrm{C}$ & $757^{\circ} \mathrm{C}$ & $796^{\circ} \mathrm{C}$ & $850^{\circ} \mathrm{C}$ & $900^{\circ} \mathrm{C}$ & $950^{\circ} \mathrm{C}$ \\
\hline toluene & - & - & - & 0.17 & 0.26 & 0.81 & 1.06 \\
\hline ethylbenzene & - & - & - & 0.08 & 0.36 & 1.09 & 1.17 \\
\hline$m / p$-xylene & - & - & - & - & - & 0.09 & 0.13 \\
\hline o-xylene & 一 & - & - & 0.07 & 0.21 & 0.47 & 0.60 \\
\hline styrene (6) & - & - & - & - & 0.39 & 2.26 & 5.74 \\
\hline benzocyclobutene (3) & - & - & 0.15 & 0.48 & 1.36 & 2.79 & 2.17 \\
\hline allylbenzene & - & - & - & - & - & 0.15 & 0.07 \\
\hline propylbenzene & - & - & - & - & - & 0.09 & 0.08 \\
\hline o-ethyltoluene & - & - & - & 0.07 & 0.31 & 0.33 & 0.13 \\
\hline o-methylstyrene & - & 0.15 & 0.21 & 0.44 & 1.60 & 2.47 & 3.09 \\
\hline benzaldehyde & - & - & - & 0.09 & 0.20 & 0.19 & 0.16 \\
\hline indan & - & - & - & - & - & 0.16 & 0.38 \\
\hline $\mathrm{m} / \mathrm{p}$-allyltoluene & 1.63 & 1.57 & 1.38 & 1.37 & 1.35 & 0.92 & 0.51 \\
\hline $\mathrm{AA}$ & - & - & - & $e$ & - & - & - \\
\hline o-allyltoluene (4) & 98.07 & 94.03 & 83.60 & 71.00 & 30.92 & 12.74 & 5.77 \\
\hline indene (8) & - & 0.68 & 1.44 & 1.99 & 9.71 & 23.93 & 39.88 \\
\hline 2-methylindan (7) & - & 2.10 & 8.37 & 17.80 & 34.85 & 28.68 & 13.07 \\
\hline 1-methylindan & - & 0.17 & 0.62 & 1.31 & 1.86 & 1.30 & 0.57 \\
\hline $\mathrm{AB}-132\left[\mathrm{C}_{10} \mathrm{H}_{12}\right]$ & - & - & 一 & - & 0.14 & 0.29 & 0.30 \\
\hline $\mathrm{TD}-130\left[\mathrm{C}_{10} \mathrm{H}_{10} \mathrm{O}\right.$ & - & - & - & - & 0.40 & 1.74 & 4.26 \\
\hline o-methylbenzaldehyde & - & 0.10 & 0.11 & 0.07 & 0.16 & - & - \\
\hline
\end{tabular}

Table A-V continues on next page 
Table A-v. Continued

\begin{tabular}{|c|c|c|c|c|c|c|c|}
\hline \multirow[b]{2}{*}{ entry } & \multicolumn{7}{|c|}{ yield, $\% c$} \\
\hline & $\mathrm{RT} d$ & $700^{\circ} \mathrm{C}$ & $757^{\circ} \mathrm{C}$ & $796^{\circ} \mathrm{C}$ & $850^{\circ} \mathrm{C}$ & $900^{\circ} \mathrm{C}$ & $950^{\circ} \mathrm{C}$ \\
\hline$o-(1-$ propenyl) toluene & - & 0.16 & 0.79 & 1.91 & 6.35 & 7.92 & 5.86 \\
\hline $\mathrm{TH}-130\left[\mathrm{C}_{10} \mathrm{H}_{10}\right]$ & - & - & - & - & - & - & 0.07 \\
\hline $\mathrm{TI}-132\left[\mathrm{C}_{10} \mathrm{H}_{12}\right]$ & - & - & - & - & 0.27 & 0.59 & 0.65 \\
\hline 3-methyl-1H-indene & - & - & - & - & 0.83 & 2.12 & 5.93 \\
\hline tetralin (1) & - & 0.27 & 0.83 & 1.95 & 5.18 & 5.37 & 3.86 \\
\hline 2-methyl-1H-indene & - & 0.11 & 0.29 & 0.19 & 0.45 & 0.47 & 0.39 \\
\hline $\mathrm{TK}-130\left[\mathrm{C}_{10} \mathrm{H}_{10}\right]$ & - & - & 0.47 & 0.35 & 1.00 & 1.04 & 0.85 \\
\hline 1,2-dihydronaphthalene (2) & - & 0.56 & 1.38 & 0.54 & 0.95 & 0.80 & 0.50 \\
\hline $\mathrm{TL}-128\left[\mathrm{C}_{10} \mathrm{H}_{8}\right]$ & - & - & - & - & - & - & 0.14 \\
\hline naphthalene (5) & 0.30 & 0.11 & 0.34 & 0.12 & 0.89 & 1.12 & 2.51 \\
\hline TO- $148\left[\mathrm{C}_{11} \mathrm{H}_{16}\right]$ & - & - & - & - & - & 0.06 & 0.08 \\
\hline recovery $f$ & 93.99 & 84.00 & 81.25 & 88.33 & 74.00 & 80.14 & 69.83 \\
\hline conversion $g$ & $d$ & 5.97 & 16.40 & 29.00 & 69.08 & 87.26 & 94.23 \\
\hline
\end{tabular}

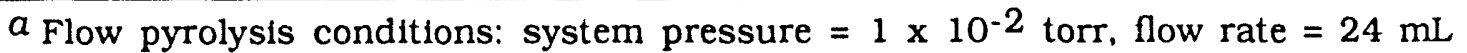
$\min ^{-1}$ (Ar), residence time $=0.31 \mathrm{~s} .{ }^{b}$ Amounts determined by GC with a known quantity of biphenyl added as standard. Data represent the average of triplicate runs. Products identified by comparison with authentic samples or those that could be identified by retention time and GCMS are indicated by name. Products that were identified by GCMS only are indicated by code: $X Y-n n n$, where ' $X$ ' corresponds to the system studied $(A=$ pyrolysis of $4, T=$ pyrolysis of 1$), \quad Y$ to the individual unknown product (A, B, C, etc.), and 'nnn' to the nominal mass. $c$ See Table A-I, footnote $c . d$ See Table A-I, footnote $d$. $e$ See Table A-II, footnote $e . f$ See Table A-I, footnote $f . g$ See Table A-I, footnote $g$. 
Table A-v1. Products and recovered starting material, total recovery of material, and conversion from the flow pyrolysis of 1,2-dihydronaphthalene (2) at various oven temperatures $a, b$

\begin{tabular}{|c|c|c|c|c|}
\hline \multirow[b]{2}{*}{ entry } & \multicolumn{4}{|c|}{ yleld, \% $c$} \\
\hline & $\mathrm{RT} d$ & $800^{\circ} \mathrm{C}$ & $850^{\circ} \mathrm{C}$ & $903^{\circ} \mathrm{C}$ \\
\hline indene (8) & - & 0.11 & 0.73 & 2.43 \\
\hline TD- $130\left[\mathrm{C}_{10} \mathrm{H}_{10}\right]$ & - & 0.10 & 0.52 & 1.45 \\
\hline TF-130 $\left[\mathrm{C}_{10} \mathrm{H}_{10} \mathrm{l}\right.$ & - & 0.27 & 0.27 & - \\
\hline $\mathrm{TH}-130\left[\mathrm{C}_{10} \mathrm{H}_{10} \mathrm{l}\right.$ & - & 0.34 & 0.77 & 0.72 \\
\hline 3-methyl- $1 H$-indene & - & 0.21 & 0.69 & 1.86 \\
\hline tetralin (1) & 0.28 & 0.31 & 0.31 & 0.28 \\
\hline 2-methyl-1H-indene & - & - & 0.10 & 0.33 \\
\hline 1,2-dihydronaphthalene (2) & 99.72 & 89.91 & 73.23 & 31.09 \\
\hline TL- $128\left[\mathrm{C}_{10} \mathrm{H}_{8}\right]$ & - & 0.06 & - & 0.12 \\
\hline naphthalene (5) & - & 8.68 & 23.38 & 61.72 \\
\hline recovery $e$ & 92.59 & 80.10 & 90.33 & 83.07 \\
\hline conversion $f$ & $d$ & 10.09 & 26.77 & 68.91 \\
\hline
\end{tabular}

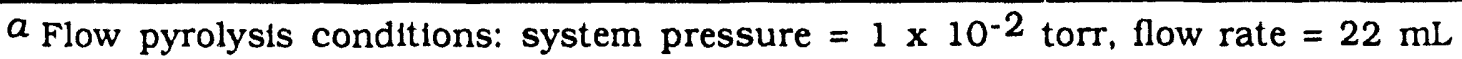
$\mathrm{min}^{-1}(\mathrm{Ar})$, residence time $=0.31 \mathrm{~s} .{ }^{b}$ See Table A-I, footnote $b .{ }^{c}$ See Table A-I, footnote c. $d$ See Table A-I, footnote $d$. $e$ See Table A-I, footnote $f$. $f$ See Table A-I, footnote $g$. 


\section{APPENDIX 2}

\section{SUPPLEMENTARY PROCEDURES AND CALCULATIONS}

\section{Detalled procedure for flow pyrolysis}

Initially, the flow pyrolysis apparatus (Figure 2, Paper 1) was filled with Ar. The pyrolysis portion of the apparatus was isolated from the sample chamber and flow control assembly with the three-way ball valve nearest the pyrolysis oven. After the pyrolysis portion of the apparatus had been evacuated, both the flow and bypass lines of the flow control assembly were purnped down. (CAUTION: Open the three-way ball valve slowly whenever a pressure difference exists. If released suddenly, the gas at higher pressure in the flow and bypass lines of the flow assembly or the sample chamber will push the hot chips from the pyrolysis oven into the trap. The ball valve is not designed to be a metering valve and should be left fully open or fully closed.) When both branches of the flow control assembly had reached the minimum pressure, the sample chamber was evacuated to ca. 15 in. vacuum (ca. $\frac{1}{2}$ total volume) through the flow line (needle valve fully open) and then the rest of the Ar was removed through the bypass line (CAUTION: Pressure difference across three-way ball valve). This procedure was repeated at least three times and the entire apparatus was evacuated for at least $12 \mathrm{hr}$ (flow assembly on bypass).

A weighed sample in a $5-\mathrm{mL} 14 / 20$ round-bottom flask flushed with Ar was attached to the sample inlet with a small amount of vacuum grease. The sample was frozen with liquid $\mathrm{N}_{2}$ and the sample inlet opened. After the system had returned to the minimum pressure $(30-60 \mathrm{~min})$, the sample inlet was closed and the sample allowed to warm to room temperature. The sample was refrozen with liquid $\mathrm{N}_{2}$ and opened to the 
pump for an additional $15-30 \mathrm{~min}$. The sample chamber was isolated from the flow assembly and pyrolysis apparatus with the three-way ball valve nearest the sample chamber. The sample inlet was opened and the sample was allowed to warm to room temperature. No liquid sample remained in the flask. The sample chamber was flled with Ar to atmospheric pressure through the gas inlet. The gas inlet was closed and the gas mixture was allowed to equilibrate for $15 \mathrm{~min}$. The pyrolysis trap was cooled with liquid $\mathrm{N}_{2}$. The flow of gas mixture into the previously equilibrated pyrolysis oven was maintained at a fixed rate of $20-25 \mathrm{~mL} \mathrm{~min}-1$ (Ar/1 atm/flow tube $=60$ (glass), 30 (SS)) unt

the sample chamber was evacuated to 15 in. vacuum (ca. $\frac{1}{2}$ total volume). When the pyrolysis was complete $(c a .5 \mathrm{hr}$ ), the sample chamber and flow control assembly were isolated from the pyrolysis apparatus with the three-way ball valve nearest the pyrolysis oven. The pyrolysis portion of the apparatus was then filled with $\mathrm{N}_{2}$. After the trap had warmed to near room temperature, the trap was removed and $0.5 \mathrm{~mL}$ biphenyl in $\mathrm{CH}_{2} \mathrm{Cl}_{2}$ (ca. $2 \mathrm{mg} \mathrm{mL}^{-1}$ ) and an additional $0.5 \mathrm{~mL} \mathrm{CH}_{2} \mathrm{Cl}_{2}$ was added to the trap. The trap was thoroughly rinsed with the solution, which was immediately analyzed by GC.

After a clean trap was put in place, the pyrolysis portion of the apparatus was filled with $\mathrm{N}_{2}$ and evacuated several times. The remaining sample in the sample chamber was removed through the bypass line (CAUTION: Pressure difference across three-way ball valve). The apparatus was filled with $\mathrm{Ar}$ and evacuated as described above and allowed to pump down at least $12 \mathrm{~h}$ (flow assembly on bypass) before repeat use.

\section{Calculation of residence time for flow pyrolysis}

To calculate the residence time, the volume of the pyrolysis oven was measured. The pyrolysis run time is an average of many runs and represents the time necessary to evacuate the sample chamber from 0 to $15 \mathrm{in}$. vacuum at $20-25 \mathrm{~mL} \mathrm{~min}^{-1}(\mathrm{Ar} / 1 \mathrm{~atm})$. 


\section{Volume of oven (Voven)}

Mass of chips + mass of graduated cylinder $=m_{1}$

$171.25 \mathrm{~g}$

Mass of water + mass of chips + mass of graduated

cylinder $=\mathrm{mf}_{\mathrm{f}}$

$248.92 \mathrm{~g}$

Mass of water $=m_{W}=m_{f} \cdot m_{1}$

$77.76 \mathrm{~g}$

Volume of water $=\mathrm{V}_{\mathrm{w}}=\mathrm{m}_{\mathrm{w}}$

$77.76 \mathrm{~mL}$

Volume of chips + volume of water $=\mathrm{V}_{\mathrm{f}}$

$100.0 \mathrm{~mL}$

Volume of chips $=V_{\text {chips }}=V_{f}-V_{W}$

$22.3 \mathrm{~mL}$

Volume of tube $=V_{\text {tube }}=\pi r^{2} \mathrm{~h}=\pi(1.2 \mathrm{~cm})^{2}(30 \mathrm{~cm})$

$135.7 \mathrm{~mL}$

Volume of oven $=V_{\text {oven }}=V_{\text {tube }}-V_{\text {chips }}$

$113.4 \mathrm{~mL}$

\section{Volume of sample at 760 torr and $30 n k$ (VS1)}

Pressure of sample (from Bourdon gauge)

Initial pressure of sample $=P_{1}$

Final pressure of sample $=\mathrm{Pf}_{\mathrm{f}}$

Minimum pressure of system $=\mathrm{P}_{\min }$

Total volume of sample $=\mathrm{V}_{\mathrm{T}}$

Volume of sample $=V_{S 1}=\frac{P_{f}-P_{1}}{P_{\min }-P_{1}} V_{T}$
$P_{1}=0$ in. vacuum

$\mathrm{P}_{\mathrm{f}}=15$ in. vacuum

$P_{\min }=28$ in. vacuum

12 L

$6.4 \quad$ L

Volume of sample at 0.78 torr and $1100 \mathrm{~K}$ (VS2)

Initial pressure of sample $=\mathrm{P}_{1}$

Final pressure of sample $=\mathrm{P}_{2}$

Initial temperature of sample $=T_{1}$

Final temperature of sample $=\mathrm{T}_{2}$

Initial volume of sample $=V_{S 1}$

Volume of sample $=V_{S 2}=\frac{P_{1} T_{2}}{P_{2} T_{1}} V_{S 1}$
760 torr

0.78 torr

$300 \mathrm{~K}$

$1100 \mathrm{~K}$

6.4 L

$2.3 \times 10^{7} \mathrm{~mL}$ 
Flow rate ( $\left.R_{f}\right)$

Average run time $=t_{s}$

Flow rate $=R_{f}=V_{S 2} / t_{s}$

Residence time $\left(t_{r}\right)$

Residence time $=t_{r}=V_{\text {oven }} / R_{f}$
$276 \mathrm{~min}$

$8.3 \times 10^{4} \mathrm{~mL} \mathrm{~min}^{-1}$

$0.08 \mathrm{~s}$ 


\section{APPENDIX 3}

\section{ADDITIONAL DATA ON THE PYROLYSIS OF TETRAIIN}

In addition to the data on the flow pyrolysis of tetralin (1) presented in Paper 1 of this dissertation, additional experiments were performed. The effects of flow rate, carrier gas, and pyrolysis tube size were examined and these data are reported here. Data on the flash vacuum pyrolysis of 1 in the presence of diluents is also presented in this appendix.

\section{Flow rate in flow pyrolysis}

The results of the pyrolysis of tetralin (1) at $850^{\circ} \mathrm{C}$ and various flow rates are presented in Table A3-I. The data at $25 \mathrm{~mL} \mathrm{~min}^{-1}$ can also be found in Table VIII of Paper 1 in this dissertation. A drop in conversion from $c a .8 \%$ to $4 \%$ and recovery from near quantitative to $60 \%$ with increasing flow rate is observed. The dehydrogenation to ethylene loss ratio increased from 0.3 to 0.7 with increasing flow rate. The reproducibllity was less at higher flow rate. The range in the dehydrogenation to ethylene loss ratio at $25 \mathrm{~mL} \mathrm{~min}-1$ was 0.23 to 0.31 , while at $95 \mathrm{~mL} \mathrm{~min}^{-1}$ the ratio ranged from 0.48 to 0.99 .

As the flow rate increases, the residence time of the sample in the pyrolysis oven decreases. The drop in conversion with increasing flow rate is expected. The decreasing recovery is most likely due to the difficulty in trapping out all of the pyrolysate at faster flow rates. The increasing dehydrogenation to ethylene loss ratio may be caused by bimolecular reactions or could be an artifact resulting from poor reproducibllity between 
Tatle A3-I. Products and recovered starting material, total recovery of material, conversion, and dehydrogenation to ethylene loss ratio from flow pyrolysis of tetralin (1) at various flow rates $a, b$

\begin{tabular}{|c|c|c|c|c|c|}
\hline \multirow[b]{2}{*}{ entry } & \multirow[b]{2}{*}{$\begin{array}{c}10 \\
\mathrm{~mL} \mathrm{~min}^{-1}\end{array}$} & \multicolumn{3}{|c|}{ yield, $\% c$} & \multirow{2}{*}{$z^{-} \cdot$} \\
\hline & & $\begin{array}{c}25 \\
\mathrm{~mL} \min ^{-1}\end{array}$ & $\begin{array}{c}45 \\
\mathrm{~mL} \min ^{-1}\end{array}$ & $\begin{array}{c}95 \\
\mathrm{~mL} \mathrm{~min}^{-1}\end{array}$ & \\
\hline tetralin (1) & 92.7 & 90.7 & 96.1 & 95.5 & Su.9 \\
\hline 1.2-dihydronaphthalene (2) & 0.9 & 1.1 & 1.0 & 1.1 & 0.9 \\
\hline naphthalene (5) & 0.3 & 0.5 & 0.2 & 0.3 & 0.1 \\
\hline benzocyclobutene (3) & 3.9 & 4.7 & 1.7 & 1.9 & 2.2 \\
\hline styrene (6) & 0.7 & 1.1 & 0.2 & 0.2 & 0.3 \\
\hline o-allyltoluene (4) & 0.9 & 1.1 & 0.7 & 0.7 & 0.6 \\
\hline 2-methylindan (7) & 0.4 & 0.6 & 0.1 & 0.2 & - \\
\hline indene (8) & 0.2 & 0.2 & - & 0.1 & - \\
\hline recovery $d$ & 98.8 & $r$ & 72.4 & 66.1 & 59.6 \\
\hline conversion $e$ & 7.3 & & 3.9 & 4.5 & 4.1 \\
\hline ratio $(2+5) /(3+6)$ & 0.26 & 0.28 & 0.65 & 0.68 & 0.38 \\
\hline \multicolumn{6}{|c|}{ 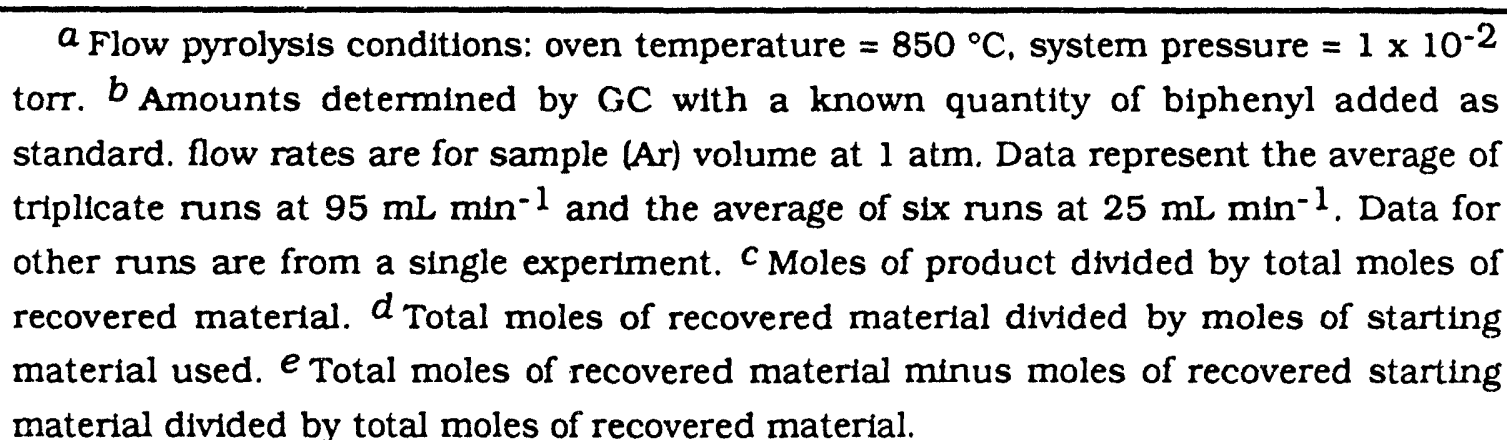 } \\
\hline
\end{tabular}


runs at the higher flow rates. The flow rate of $25 \mathrm{~mL} \mathrm{~min}-1$ was chosen for the study of the flow pyrolysis of 1 at various oven temperatures presented in Table VIII of Paper 1 in this dissertation because of the high reproducibility and convenient temperature (conversion) range at this flow rate.

\section{Carrier gas in flow pyrolysis}

Two types of experiments were done to assess the effect of carrier gas on the flow pyrolysis of 1: the use of helium as a carrier gas and the addition of hydrogen to the argon carrier gas. The data for flow pyrolysis with helium carrier gas at $850{ }^{\circ} \mathrm{C}$ are presented in Table A3-II. The recovery is only ca. $40-50 \%$ and the conversion ca. $5 \%$ for these runs. The dehydrogenation to ethylene loss ratio is between 0.1 and 0.25 . The results of the flow pyrolysis of 1 at $850{ }^{\circ} \mathrm{C}$ with $18 \%$ and $36 \%$ hydrogen (by volume) in argon as carrier gas (Table A3-III) show a recovery of $80-100 \%$ and a conversion ca. $10 \%$. The dehydrogenation to ethylene loss ratio is near 0.3 .

The flow pyrolysis of 1 was not as convenient with helium as a carrier gas as with argon. Not only was the pyrolysate recovery with helium far lower (50\% with He vs. $90 \%$ with Ar), the annoyance of listening to the roughing pump's high pitched gurgling with helium bubbling through it all day cannot be underestimated. The dehydrogenation to ethylene loss ratios are similar with the two carrier gasses but the effect of flow rate is less pronounced with helium than with argon. There were no apparent advantages of using helium as a carrier gas and argon was used for other experiments.

We also attempted to induce dehydrogenation by adding hydrogen to the argon carrier gas. The flow pyrolysis of 1 with up to $36 \%$ hydrogen (by volume) in argon is for all intents and purposes identical to pyrolysis with $100 \%$ argon $\left(25 \mathrm{~mL} \mathrm{~min}^{-1}\right.$. Table 
Table A3-II. Products and recovered starting material, total recovery of material, conversion, and dehydrogenation to ethylene loss ratio from flow pyrolysis of tetralin (1) with helium carrier gas $a, b$

\begin{tabular}{lcc}
\hline & \multicolumn{2}{c}{ yield, \% } \\
\cline { 2 - 3 } entry & 20 & 150 \\
$\mathrm{~mL} \mathrm{~min}$ & -1 & $\mathrm{~mL} \mathrm{~min}^{-1}$ \\
\hline tetralin (1) & 95.4 & 95.4 \\
1,2-dihydronaphthalene (2) & 0.5 & 0.7 \\
benzocyclobutene (3) & 2.9 & 2.9 \\
styrene (6) & 0.4 & 0.3 \\
o-allyltoluene (4) & 0.7 & 0.6 \\
2-methylindan (7) & 0.2 & - \\
recovery $d$ & & 52.2 \\
conversion $e$ & 40.8 & 4.6 \\
\hline ratio 2/(3 + 6) & 4.6 & 0.21 \\
\hline
\end{tabular}

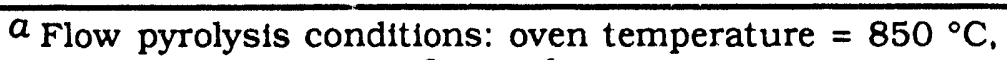
system pressure $=1 \times 10^{-2}$ torr. $b$ Amounts determined by GC with a known quantity of biphenyl added as standard. flow rates are for sample (He) volume at 1 atm. Data are from a single experiment at each flow rate. $c$ See Table A3-I, footnote $c . d$ See Table A3-I, footnote $d$. $e$ See Table A3-I, footnote $e$. 
Table A3-III. Products and recovered starting material, total recovery of material, conversion, and dehydrogenation to ethylene loss ratio from flow pyrolysis of tetralin (1) with hydrogen in argon carrier gas $a, b$

\begin{tabular}{lcc}
\hline & \multicolumn{2}{c}{ ydeld, \% } \\
\cline { 2 - 3 } entry & $\begin{array}{c}18 \% \mathrm{H}_{2} \\
\text { in Ar }\end{array}$ & $\begin{array}{c}36 \% \mathrm{H}_{2} \\
\text { in Ar }\end{array}$ \\
\hline tetralin (1) & 88.8 & 91.7 \\
1.2-dihydronaphthalene (2) & 1.2 & 1.0 \\
naphthalene (5) & 0.6 & 0.6 \\
benzocyclobutene (3) & 6.0 & 4.4 \\
styrene (6) & 1.3 & 0.8 \\
o-allyltoluene (4) & 1.2 & 1.1 \\
2-methylindan (7) & 0.6 & 0.4 \\
indene (8) & 0.2 & 0.1 \\
o-(1-propenyl)toluene & 0.1 & - \\
& & 84.7 \\
recovery $d$ & 100 & 8.3 \\
conversion $e$ & 11.2 & 0.28 \\
\hline ratio (2 + 5)/(3 + 6) & 0.24 & 850 \\
\hline
\end{tabular}

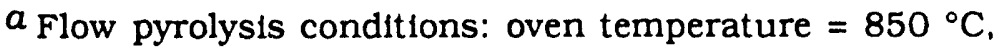
system pressure $=1 \times 10^{-2}$ torr. ${ }^{b}$ Amounts determined by GC with a known quantity of biphenyl added as standard. flow rates are for sample ( $\mathrm{H}_{2}$ in $\mathrm{Ar}$ ) volume at $1 \mathrm{~atm}$. Data are from a single experiment with each gas mixture. $c$ See Table A3-I, footnote $c$. $d$ See Table A3-I, footnote $d$. $^{e}$ See Table A3-I, footnote $e$. 
A3-1). The recovery and conversion data are similar and no increase in dehydrogenation was observed. flow pyrolysis with larger amounts of hydrogen was not attempted because of the potential explosive hazard associated with this experiment.

\section{Pyrolysis tube size in flow pyrolysis}

We also have studied the effect of a narrow $3 \mathrm{~mm}$ (id) pyrolysis tube on the flow pyrolysis of 1 (Table A3-IV). The recovery is between 10\% and 50\% and the conversion from $1 \%$ to $15 \%$ for pyrolysis at $800-940{ }^{\circ} \mathrm{C}$. The dehydrogenation to ethylene loss ratio is ca. 0.3 , except for the run at $850^{\circ} \mathrm{C}$, where the conversion is $<1 \%$, the ratio is $>1$.

The results of the flow pyrolysis of 1 with the $3 \mathrm{~mm}$ pyrolysis tube are very similar to those with the normal pyrolysis tube with chip packing. The recovery was generally lower with the $3 \mathrm{~mm}$ tube but the dehydrogenation to ethylene loss ratios and product distributions were comparable, except for the run at $850{ }^{\circ} \mathrm{C}$. However, the conversion is so low for this run that the ratio will have a large error. This tube is so narrow that it is difficult to work with. Note that the flow rates were markedly different at $850{ }^{\circ} \mathrm{C}$ and $940{ }^{\circ} \mathrm{C}$ even though the setting on the flow meter was the same. This experiment should be more practical with a tube of slightly larger diameter, perhaps 5-6 mm (id).

\section{Copyrolysis with diluents in FVP}

We have also copyrolyzed 1 in the presence of diluents, some of which are expected to act as hydrogen atom chain terminators. The dehydrogenation to ethylene loss ratios for the FVP of 1 at $900^{\circ} \mathrm{C}$ (system pressure $=10^{-5}$ torr, sample temperature $=$ RT) with ca. 5, 10, and 20 fold excess by mass of toluene are $0.90,0.68$, and 0.50 , 
Table A3-IV. Products and recovered starting material, total recovery of material, and conversion from flow pyrolysis of tetralin (1) with $3 \mathrm{~mm}$ (id) pyrolysis tube $a, b$

\begin{tabular}{lccc}
\hline & \multicolumn{3}{c}{ yield, \% c } \\
\cline { 2 - 4 } entry & $800^{\circ} \mathrm{C} d$ & $850^{\circ} \mathrm{C} e$ & $940{ }^{\circ} \mathrm{C} e$ \\
\hline tetralin (1) & 84.1 & 99.1 & 94.0 \\
1.2-dihydronaphthalene (2) & 2.3 & 0.4 & 1.2 \\
naphthalene (5) & 0.7 & - & - \\
benzocyclobutene (3) & 7.9 & 0.3 & 3.6 \\
styrene (6) & 1.7 & - & - \\
o-allyltoluene (4) & 2.0 & 0.2 & 1.2 \\
2-methylindan (7) & 0.8 & - & - \\
indene (8) & 0.5 & - & - \\
& & & \\
recovery $f$ & 30.5 & 46.4 & 13.6 \\
conversion $g$ & 15.9 & 0.93 & 6.0 \\
\hline ratio (2 + 5) $/(3+6)$ & 0.32 & 1.29 & 0.33 \\
\hline a & &
\end{tabular}

$a$ Flow pyrolysis conditions: system pressure $=1 \times 10^{-2}$ torr. $b$ Amounts determined by GC with a known quantity of biphenyl added as standard. flow rates are for sample (Ar) volume at $1 \mathrm{~atm}$. Data are from a single experiment at each temperature. ${ }^{c}$ See Table A3-I, footnote $c$. $^{d}$ Flow rate $=10$ $\mathrm{mL} \mathrm{min}^{-1}(\mathrm{Ar} / 1 \mathrm{~atm}) . e^{e}$ The flow setting on the flow meter was identical for these two runs but the flow rate was substantially different: flow rate $\left(850^{\circ} \mathrm{C}\right)=57 \mathrm{~mL} \mathrm{~min}{ }^{-1}$. flow rate $\left(940^{\circ} \mathrm{C}\right)=84 \mathrm{~mL} \mathrm{~min}^{-1} . f_{\text {See Table A3-I, footnote }}$ d. $g$ See Table A3-I, footnote $e$. 
respectively. Similar experiments with 5,10 , and 20 fold excess by mass of benzene leads to dehydrogenation to ethylene loss ratios of $0.96,0.58$, and 0.82 , respectively. When the less volatlle diluent 2-chloro-p-xylene is copyrolyzed in a 5 fold excess by mass with 1 the dehydrogenation to ethylene loss ratio is 0.39 . By comparison, the dehydrogenation to ethylene loss ratio for the FVP of 1 alone at $900{ }^{\circ} \mathrm{C}$ under these conditions is 1.04 . When less volatile diluents 2-chloro-p-xylene and mesitylene are copyrolyzed in a 5 fold excess by mass with 1 at $800^{\circ} \mathrm{C}$ (system pressure $=10^{-5}$ torr, sample temperature $=\mathrm{RT}$ ), the dehydrogenation to ethylene loss ratios are 0.71 and 0.57 , respectively. By comparison, the dehydrogenation to ethylene loss ratio for the FVP of 1 alone at $800{ }^{\circ} \mathrm{C}$ under these conditions is 1.08 .

The experiments with toluene and benzene were designed to differentiate between the dilution effect of the addition of these compounds to the sample and the hydrogen atom chain terminating effect of toluene. The results show that both pyrolyses are nearly identical up to a 10 fold excess of diluent. There is no evidence that toluene is reducing dehydrogenation more than benzene, indicating that the main effect is dilution rather than hydrogen atom chain termination. The likely cause of the reversal at 20 fold excess of diluent is crystallization of the benzene sample when it is cooled prior to pyrolysis. At 20 fold excess of benzene, the tetralin (1) in the mixture may be located between crystal planes and, therefore, easily removed by the vacuum leaving the benzene behind in the sample chamber. The toluene sample, on the other hand, forms a glass when cooled and the same effect is not observed.

The high volatility of toluene in comparison to 1 may have made it an ineffective hydrogen atom chain terminator so we chose some less volatile methylated benzene rings as diluents. When 2-chloro-p-xylene and mesitylene were copyrolyzed with 1 . dehydrogenation was reduced more than in copyrolysis with either toluene or benzene, 
with mesitylene reducing dehydrogenation more than 2 -chloro-p-xylene. This could be interpreted as a hydrogen atom chain termination being proportional to the number of methyl groups on the benzene rings.

The data presented above could be the result of heat transfer effects. The diluents may be acting as heat transfer agents effectively raising the temperature of the pyrolysis and reducing the dehydrogenation to ethylene loss ratio. The greater the excess of diluent the greater the effect, with the anomalous benzene result at 20 fold excess explained as above. The greater effect of 2-chloro-p-xylene and mesitylene could be due to their lower volatility maring them more effective heat transfer agents. The apparent difference between the two could be to due to dehydrogenation induced by chlorine atoms produced by hydrodehalogenation from 2-chloro-p-xylene. 
PAPER 2. THE FLASH VACUUM PYROLYSIS OF 3-BENZOCYCLOHEPTENONE AND

1,3,4,5-TETRAHYDRO-2-BENZOTHIEPIN-2,2-DIOXIDE: MODEL SYSTEMS FOR THE GAS-PHASE PYROLYSIS OF TETRALIN 


\section{INTRODUCTION}

The gas-phase thermal decomposition of tetralin (1) gives rise to several products (Scheme I). 1,2 The major products include primary products 1,2-dihydronaphthalene (2), benzocyclobutene (3), and o-allyltoluene (4). Secondary products, naphthalene (5) from 2. styrene (6) from 3,2 -methylindan $(7)^{3}$ from 4 , and indene (8) primarily from 7. have been identified along with various minor products.

The thermal decomposition of $\mathbf{1}$ is believed to involve cleavage of the weak benzylic carbon-carbon bond to form diradical 9. As part of our effort to understand the

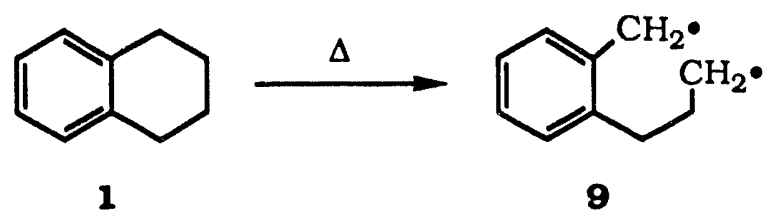

thermal decomposition of 1 , we have studied the flash vacuum pyrolysis (FVP) of some model systems that could produce 9 . It was hoped that the loss of carbon monoxide from 3-benzocycloheptenone (10) and sulfur dioxide from 1,3,4,5-tetrahydro-2-benzoth1-

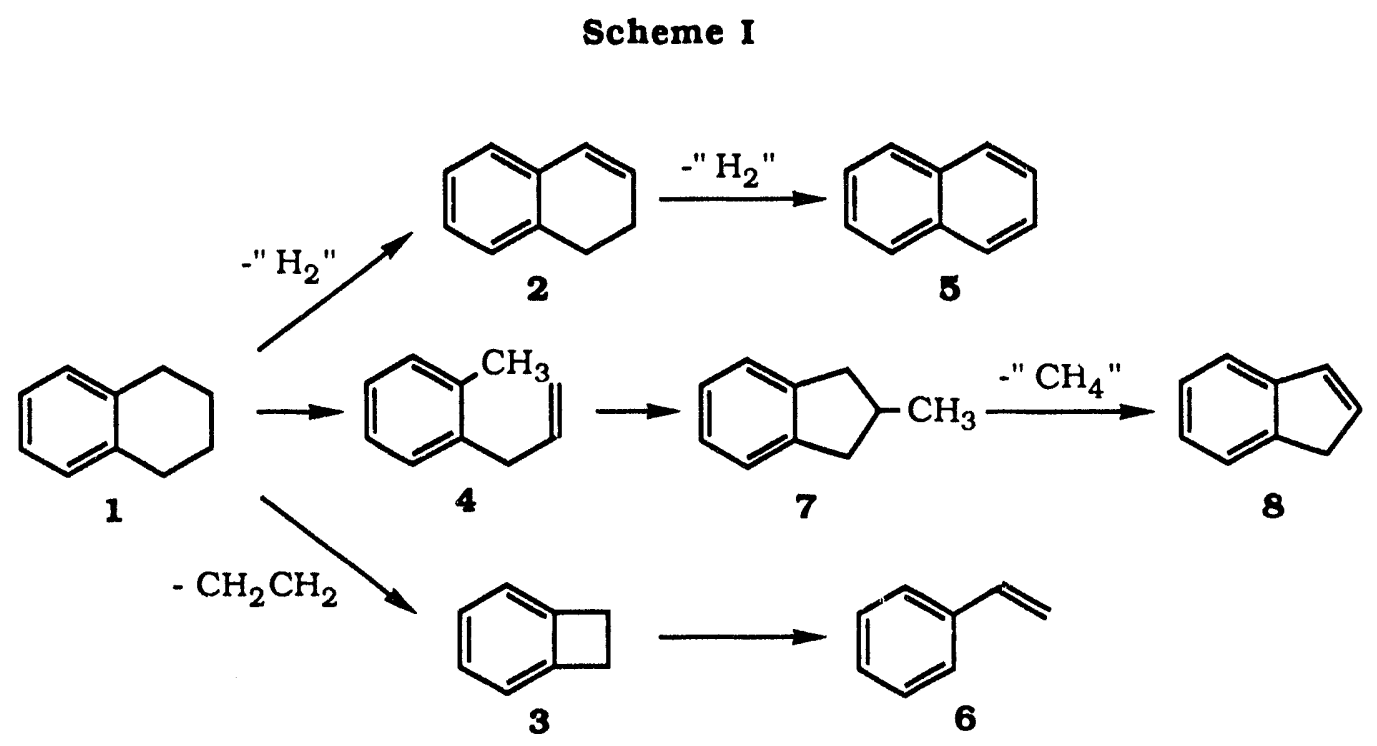


epin-2,2-dioxide (11) would involve the formation of intermediate 9 . Our studies of the

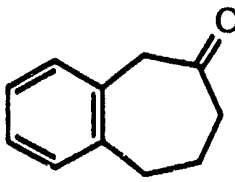

10

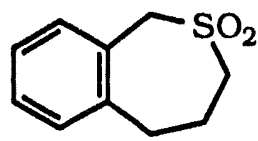

11

FVP of ketone 10 and sulfone 11 and the photolysis of ketone 10 are presented in this paper. We also present a study of the pyrolysis of 10 under flow pyrolysis conditions that was conducted to discover to what extent the chemistry observed from FVP involves bimolecular reactions. 
3-Benzocycloheptenone (10) and 1,3,4,5-tetrahydro-2-benzothiepin-2,2-dioxide (11) were prepared by the reaction sequences shown in Scheme II.

When 3-benzocycloheptenone (10) was pyrolyzed at $10^{-5}$ torr, the major products were tetralin (1), 1,2-dihydronaphthalene (2), naphthalene (5), indene (8), 1-methylnaphthalene (12), and 2-methylnaphthalene (13). At $700^{\circ} \mathrm{C}$, no benzocyclobutene (3) or styrene (6) was detected; only at $850-900^{\circ} \mathrm{C}$ were more substantial amounts of 3 and $\mathbf{6}$ observed. These results are summarized in Table I.

Ketone 10 was also pyrolyzed under flow conditions (Table II) to investigate the possibility that bimolecular reactions were occurring in the FVP experiments. Comparable amounts of the major FVP products were also produced in the flow pyrolysis.

The results of the photolysis of $10(\lambda>280 \mathrm{~nm})$ in the presence of methanol are presented in Table III. The major products produced were 1 and 4. A small amount of methyl ester 14 was also detected. We could not isolate this compound because of the

\section{Scheme II}<smiles>O=C1CCCc2ccccc21</smiles>

$\frac{\mathrm{CH}_{3} \mathrm{PPh}_{3} \mathrm{Br}}{\mathrm{NaCH}_{2} \mathrm{SOCH}_{3}}$<smiles>C=C1CCCc2ccccc21</smiles>

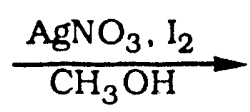<smiles>O=C1CCCc2ccccc2C1</smiles>

10<smiles>C1=Cc2ccccc2CC1</smiles>

2

\section{1. $\mathrm{O}_{3}$ \\ 2. $\mathrm{LiAlH}_{4}$}<smiles>BrCCCc1ccccc1CBr</smiles>
$\mathrm{Br}$ $\frac{1 . \mathrm{Na}_{2} \mathrm{~S}}{2 \cdot \mathrm{m}-\mathrm{CPBA}}$<smiles>O=S1(=O)CCCc2ccccc2C1</smiles>

11 


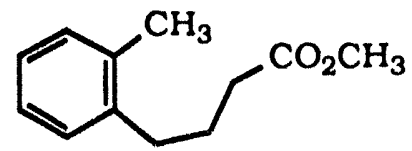

14

limited quantity, but the mass spectrum is consistent with structure 14 and none of the other products detected have the formula $\mathrm{C}_{12} \mathrm{H}_{16} \mathrm{O}_{2}$.

The results from the FVP of sulfone 11 are strikingly different from those for ketone 10 (Table IV). The major product observed was tetralin (1), but some $o$-allyltoluene (4) was also detected. All the other products were produced in only minor amounts. 
Table I. Products and recovered starting material from FVP of 3-benzocycloheptenone (10) at various oven temperatures $a, b$

\begin{tabular}{|c|c|c|c|c|c|}
\hline \multirow[b]{2}{*}{ entry } & \multicolumn{5}{|c|}{ yield, $\% c$} \\
\hline & $700^{\circ} \mathrm{C}$ & $750^{\circ} \mathrm{C}$ & $800^{\circ} \mathrm{C}$ & $850^{\circ} \mathrm{C}$ & $900^{\circ} \mathrm{C}$ \\
\hline 3-benzocycloheptenone (10) & 93.3 & 88.6 & 63.6 & 38.6 & 11.9 \\
\hline tetralin (1) & 0.2 & 1.1 & 6.5 & 14.9 & 19.9 \\
\hline 1,2-dihydronaphthalene (2) & 0.7 & 1.3 & 3.4 & 5.7 & 5.6 \\
\hline naphthalene (5) & 0.4 & 0.6 & 2.2 & 4.7 & 10.2 \\
\hline benzocyclobutene (3) & - & 0.1 & 0.7 & 2.0 & 4.2 \\
\hline styrene (6) & - & 0.2 & 0.4 & 1.1 & 4.0 \\
\hline o-allyltoluene (4) & - & 0.2 & 0.8 & 1.8 & 1.9 \\
\hline 2-methylindan (7) & - & - & 0.2 & 0.8 & 1.6 \\
\hline indene (8) & 0.2 & 0.7 & 3.3 & 8.2 & 15.3 \\
\hline 1-methylnaphthalene (12) & 1.5 & 2.6 & 8.1 & 8.4 & 6.6 \\
\hline 2-methylnaphthalene (13) & 0.6 & 1.1 & 3.1 & 3.5 & 3.0 \\
\hline other products & $2.9^{d}$ & $3.4^{d}$ & $7.6^{d}$ & $10.3^{d}$ & $15.4 d$ \\
\hline recovery $e$ & 90.1 & 83.7 & 84.0 & 78.4 & 66.7 \\
\hline conversion $f$ & 6.7 & 11.4 & 36.4 & 61.5 & 88.1 \\
\hline
\end{tabular}

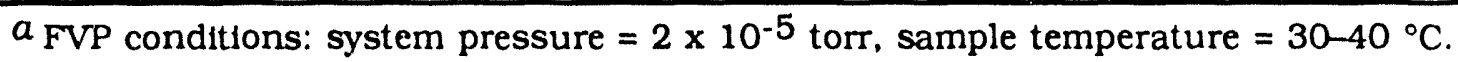
$b$ Amounts determined by GC with a known quantity of biphenyl added as standard. Data represent the average of triplicate runs. ${ }^{c}$ Moles of product divided by total moles of recovered material. $d$ See Table A-I in the Appendix of Paper 2, this dissertation, for a more detalled analysis. $e^{e}$ Total moles of recovered material divided by moles of starting material used. $f$ Total moles of recovered material minus moles of ecovered starting material dtvided by moles of recovered material. 
Table $\mathrm{n}$. Products and recovered starting material from flow pyrolysis of 3-benzocycloheptenone (10) at various oven temperatures $a, b$

\begin{tabular}{lcccc}
\hline & \multicolumn{4}{c}{ yleld, \% $\mathrm{c}$} \\
\cline { 2 - 5 } entry & $750^{\circ} \mathrm{C}$ & $800^{\circ} \mathrm{C}$ & $850^{\circ} \mathrm{C}$ & $900^{\circ} \mathrm{C}$ \\
\hline 3-benzocycloheptenone (10) & 90.2 & 79.8 & 49.8 & 12.2 \\
tetralin (1) & 2.1 & 6.3 & 18.7 & 29.3 \\
1.2-dihydronaphthalene (2) & 1.0 & 1.1 & 2.4 & 3.2 \\
naphthalene (5) & 0.7 & 0.8 & 2.0 & 3.7 \\
benzocyclobutene (3) & - & 0.5 & 1.7 & 8.0 \\
styrene (6) & - & - & 0.4 & 4.1 \\
O-allyltoluene (4) & 0.6 & 1.0 & 2.1 & 3.9 \\
2-methylindan (7) & - & - & 0.7 & 2.6 \\
indene (8) & 0.4 & 1.3 & 4.2 & 10.4 \\
1-methylnaphthalene (12) & 1.9 & 3.5 & 7.8 & 8.6 \\
2-methylnaphthalene (13) & 0.8 & 1.4 & 3.2 & 3.6 \\
other products & $2.4 \mathrm{~d}$ & $4.5 \mathrm{~d}$ & $6.9 \mathrm{~d}$ & $10.4 \mathrm{~d}$ \\
& & & & 87.8 \\
recovery $e$ & 54.0 & 50.4 & 52.3 & 45.9 \\
conversion $f$ & 9.8 & 20.2 & 50.2 & \\
\hline
\end{tabular}

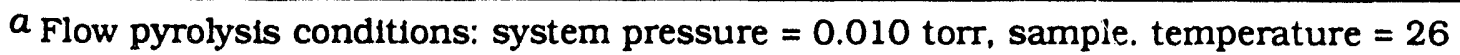
${ }^{\circ} \mathrm{C}$, flow rate $=450 \mathrm{~mL} \mathrm{~min}{ }^{-1}(\mathrm{Ar} / 1 \mathrm{~atm})$ for $10 \mathrm{~h}$, residence time $=0.28 \mathrm{~s}$. ${ }^{b}$ See Table $\mathrm{I}$, footnote $b .{ }^{c}$ See Table I, footnote $c{ }^{d}$ See Table A-II in the Appendix of Paper 2, this dissertation, for a more detalled analysis. e See Table I, footnote $e$. $f$ See Table I, footnote $f$. 
Table II. Products and recovered starting material from photolysis of 3-benzocycloheptenone (10) $a, b$

\begin{tabular}{|c|c|c|c|c|c|c|}
\hline \multirow[b]{2}{*}{$\begin{array}{l}\text { recovery. } \\
\% d\end{array}$} & \multirow[b]{2}{*}{$\begin{array}{c}\text { conversion, } \\
\% e \\
\end{array}$} & \multicolumn{5}{|c|}{ yield, \% c } \\
\hline & & 10 & 1 & 4 & $14 f$ & $\begin{array}{l}\text { other } \\
\text { prods. }\end{array}$ \\
\hline 72.4 & 15.8 & 84.2 & 8.1 & 2.7 & 1.4 & 3.79 \\
\hline
\end{tabular}

$a$ Photolysis conditions: $[10]=0.33 \mathrm{mM}$ in $11: 1$ (v:v) pentanes:methanol, medium pressure $\mathrm{Hg}$ lamp with Pyrex filter $(\lambda>280 \mathrm{~nm}), 2 \mathrm{~h}$ at room temperature. $b$ See Table I, footnote $b .{ }^{c}$ See Table I, footnote $c$. $d$ See Table I, footnote $e . e^{e}$ See Table I, footnote f. $f \mathrm{GCMS}(\mathrm{EI}, 70 \mathrm{eV}) \mathrm{m} / \mathrm{e}$ (\% base peak) 192 (28.1), 161 (16.1), $119(29.1), 118(100), 117$ (33.6), 105 (55.5), 77 (20.6), 74 (47.1). 9 See Table A-III in the Appendix of Paper 2, this dissertation, for a more detailed analysis. 
Table IV. Products and recovered starting material from FVP of 1,3,4,5-tetrahydro-2-benzothiepin-2,2-dioxdde (11) at various oven temperatures $a, b$

\begin{tabular}{|c|c|c|c|c|}
\hline \multirow[b]{2}{*}{ entry } & \multicolumn{4}{|c|}{ yield, \% c } \\
\hline & $600^{\circ} \mathrm{C}$ & $700{ }^{\circ} \mathrm{C}$ & $800^{\circ} \mathrm{C}$ & $900^{\circ} \mathrm{C}$ \\
\hline \multicolumn{5}{|c|}{ 1,3,4,5-tetrahydro-2-benzothie- } \\
\hline pin-2,2-dioxide (11) & 84.0 & 8.5 & 0.1 & - \\
\hline tetralin (1) & 13.2 & 75.8 & 79.1 & 62.5 \\
\hline 1,2-dihydronaphthalene (2) & 0.3 & 0.9 & 2.0 & 3.4 \\
\hline naphthalene (5) & - & 0.3 & 0.9 & 4.6 \\
\hline benzocyclobutene (3) & 0.3 & 1.1 & 2.1 & 7.8 \\
\hline styrene (6) & 0.3 & 0.6 & 0.4 & 3.6 \\
\hline o-allyltoluene (4) & 2.0 & 12.5 & 11.3 & 5.4 \\
\hline 2-methylindan (7) & - & 0.2 & 2.6 & 5.2 \\
\hline indene (8) & - & 0.1 & 0.6 & 4.4 \\
\hline other products & $d$ & $d$ & $0.7^{d}$ & $2.9^{d}$ \\
\hline recovery $e$ & 83.5 & 79.0 & 72.6 & 69.4 \\
\hline conversion $f$ & 29.9 & 93.2 & 99.9 & 100 \\
\hline
\end{tabular}




\section{DISCUSSION}

A comparison of the pyrolysis chemistry of 3-benzocycloheptenone (10) and tetralin (1) reveals three major differences. First, the pyrolysis of ketone 10 produces primarily 1,2-dihydronaphthalene (2) and naphthalene (5) while, flow pyrolysis of 1 produces primarlly benzocyclobutene (3) and styrene (6).5a second, the amount of indene (8) produced from the pyrolysis of ketone 10 is much larger than the amounts of o-allyltoluene (4) and 2-methylindan (7), but these products are obtained in comparable

yields from 1.5 We have identified the pathway 4 to 7 to 8 as the major source of 8 in the decomposition of 1,5 therefore, in the decomposition of ketone 10,8 is unlikely to have resulted from the secondary pyrolysis of 4 and 7 and must have been produced by an alternate pathway. Finally, the pyrolysis of 10 leads to several $\mathrm{C}_{11} \mathrm{H}_{10}$ products, most prominently 1 -methyl (12) and 2-methylnaphthalene (13), that constitute a net loss of $\mathrm{H}_{2} \mathrm{O}$ from ketone $10\left(\mathrm{C}_{11} \mathrm{H}_{12} \mathrm{O}\right)$ and obviously have no parallel in the decomposition of 1 .

The initial step in the decomposition of 3-benzocycloheptenone (10) is expected to be breakage of the weak benzylic carbon-carbon bond leading to the formation of diradical 16 that could lose $\mathrm{CO}$ to form diradical 9. It is reasonable to expect diradical 9

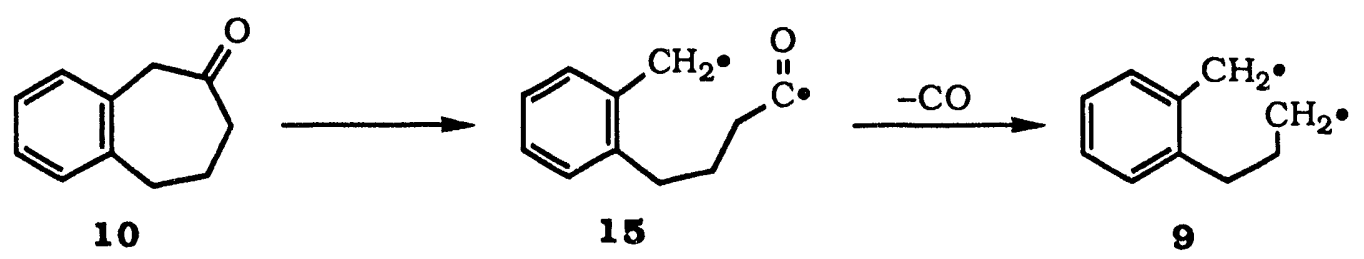

to close to form tetralin (1) and disproportionate to form o-allyltoluene (4), and both are produced in the decomposition of $\mathbf{1 0}$ under FVP (Table I) and flow pyrolysis (Table II) conditions. Photolysis of ketone 10 also yields 1 and 4. Further support for the production of 1 and 4 from diradical 9 comes from study of the pyrolysis of the strained 
hydrocarbon 16 that produces 1 and 4 as the major products and probably involves 9 as an intermediate. 6

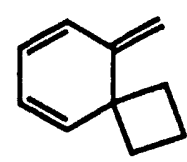

16

The production of a small amount of methyl ester 14 in the photolysis of 10 in the presence of methanol is explained by the addition of methanol to ketene 7 . This

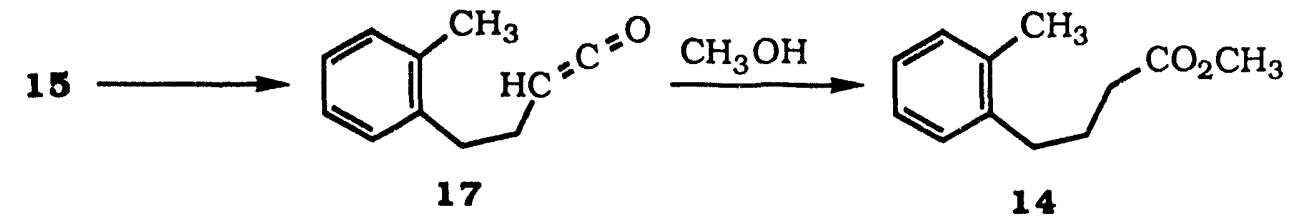

ketene could be formed from the disproportionation of carbonyl diradical 15. The observation of 14 supports the assumption that the loss of $\mathrm{CO}$ is stepwise and shows that $\mathbf{1 5}$ has an appreciable lifetime at room temperature in dilute solution.

The relative amounts of dehydrogenation products, 1,2-dihydronaphthalene (2) and naphthalene (5), to ethylene-loss products, benzocyclobutene (3) and styrene (6), produced in the pyrolysis of ketone $\mathbf{1 0}$ are also of interest. We have previously observed that ethylene loss is the lowest energy gas-phase unimolecular reaction of $1.5 a$ The flow pyrolysis of 1 produces an ethylene loss to dehydrogenation ratio of between 3 and 5 to 1 over the entire temperature range studied $\left(750-900^{\circ} \mathrm{C}\right)$. However, bimolecular dehydrogenation of 1 is the predominate reaction under some FVP conditions.

The FVP of 10 clearly produces greater amounts of dehydrogenation than ethylene loss (Table I). No 3 or 6 was detected at $700^{\circ} \mathrm{C}$; although, larger amounts are produced at $850-900^{\circ} \mathrm{C}$. This increase corresponds to a leveling off of the amount of 1 that indicates secondary pyrolysis is occurring. Even at $900^{\circ} \mathrm{C}$, the ratio of ethylene loss to dehydrogenation is ca. $0.5: 1$. 
We studied the decomposition of 10 under flow pyrolysis conditions (Table II) to eliminate possible bimolecular reactions. Both FVP and flow pyrolysis produced an excess of dehydrogenation except at the highest flow pyrolysis temperature. At $900{ }^{\circ} \mathrm{C}$, substantially less 2 and $\mathbf{5}$ is produced than in the corresponding FVP experiments. This is consistent with bimolecular dehydrogenation in the secondary decomposition of 1 during FVP. In both the FVP and flow pyrolysis of 10, the increase in the amount of 3 and 6 corresponds to a leveling off of the amount of 1 . This indicates that the ethyleneloss products appear to result from secondary decomposition of 1 . Thus, the unimolecular thermal decomposition of $\mathbf{1 0}$ appears to produce more dehydrogenation products 2 and $\mathbf{5}$ than are produced by the unimolecular decomposition of 1 . Possibly 2 and 5 are produced from diradical 15 by a route that does not involve loss of $\mathrm{CO}$ to form diradical 9.

The pyrolysis of ketone 10, whether under FVP or flow conditions, also produces more indene (8) relattve to 0 -allyltoluene (4) and 2 -methylindan (7) than is produced by tetralin (1) under similar conditions. We have shown 5 that 8 produced in the decomposition of $\mathbf{1}$ is a secondary product ultimately derived from 4 that cyclizes to 7 . The subsequent loss of a methyl group from 7 leads to the formation of 8 . We can therefore conclude that 8 produced directly from 10 derives from another reartion path. Of course, at $900-950{ }^{\circ} \mathrm{C}$ where secondary pyrolysis of 1 takes place, some 8 no doubt comes from 4 and 7 . It is difficult to quantify how much 8 is produced by the new reaction and how much from the 4 to 7 to 8 pathway at the higher pyrolysis temperatures.

The most surprising products of the pyrolysis of ketone 10 are the $\mathrm{C}_{11} \mathrm{H}_{10}$ isomers that constitute an elimination of water from ketone 10. The major water-loss products produced in the pyrolysis of 10, under both FVP and flow conditions, are 
1-methyl (12) and 2-methylnaphthalene (13). Several minor $\mathrm{C}_{11} \mathrm{H}_{10}$ products were also observed in the pyrolysis of 10 . These products are produced in diminishing amounts as the temperature is increased and appear to be precursor products to 12 and 13 . These precursor products were produced in amounts too small to be isolated but literature precedence for the transformation of $\mathrm{C}_{11} \mathrm{H}_{10}$ isomers to 12 and 13 was found. 7 Previous workers had found that benzocycloheptatrienes 18 and 19 (Scheme III) were formed in the pyrolysis of benzonorbornene. $7 \mathrm{a}$ At higher pyrolysis temperatures, 18 and 19 were converted to 12 and 13.7a One could speculate that 18 and 19 may be formed from ketone 10 through enol 20. A [1,5] hydrogen shift of 20 would form o-quinodimethane 21 . The loss of $\mathrm{H}_{2} \mathrm{O}$ from 21 would give o-quinodimethane 22 and subsequent $[1,5]$ hydrogen shifts would give 18 and 19. Benzocycloheptatriene 18 could provide a source of indene (8) if cyclization to 23 followed by the loss of acetylene occurred.

The pyrolysis of 1,3,4,5-tetrahydro-2-benzothiepin-2,2-dioxide (11) is as simple as the pyrolysis of 3-benzocycloheptenone (10) is complex. The FVP of sulfone 11 produces tetralin (1) and a small amount of o-allyltoluene (4). At higher temperatures, the products appear to derive from secondary pyrolysis of 1 .

At a given temperature, sulfone 11 decomposes to a greater extent than ketone 10. This is consistent with the benzylic-sulfonyl bond being weaker than the benzylic-carbonyl bond that is supported by bond energies. ${ }^{8}$ The ratio of tetralin (1) to o-allyltoluene (4) from sulfone 11 at lower pyrolysis temperatures $\left(7.0\right.$ at $\left.800^{\circ} \mathrm{C}\right)$ is close to that produced from the pyrolysis of ketone $10\left(6.3\right.$ at $\left.800^{\circ} \mathrm{C}\right)$ and may reflect the ratio of 1 to 4 that diradical 9 produces at this temperature. It is possible that some 1 from sulfone 11 may result from a concerted extrusion of $\mathrm{SO}_{2}$ with concurrent 
carbon-carbon bond formation. Alternately, formation of diradical 24 followed by direct conversion of 24 to 1 with concurrent loss of $\mathrm{SO}_{2}$ may be responsible.

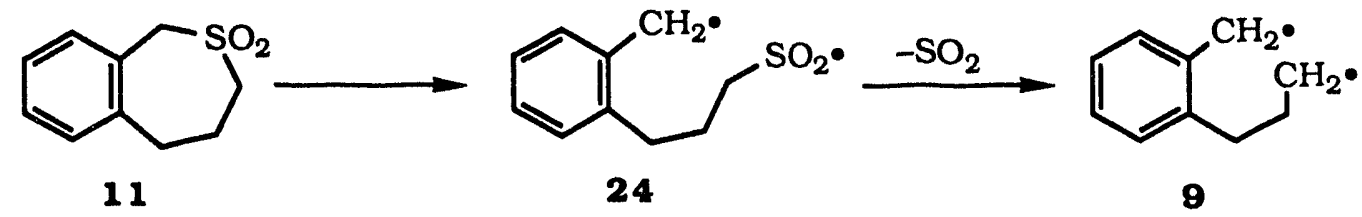

Scheme III<smiles>O=C1Cc2ccccc2CC1C=C=Cc1ccc2ccccc2c1</smiles>

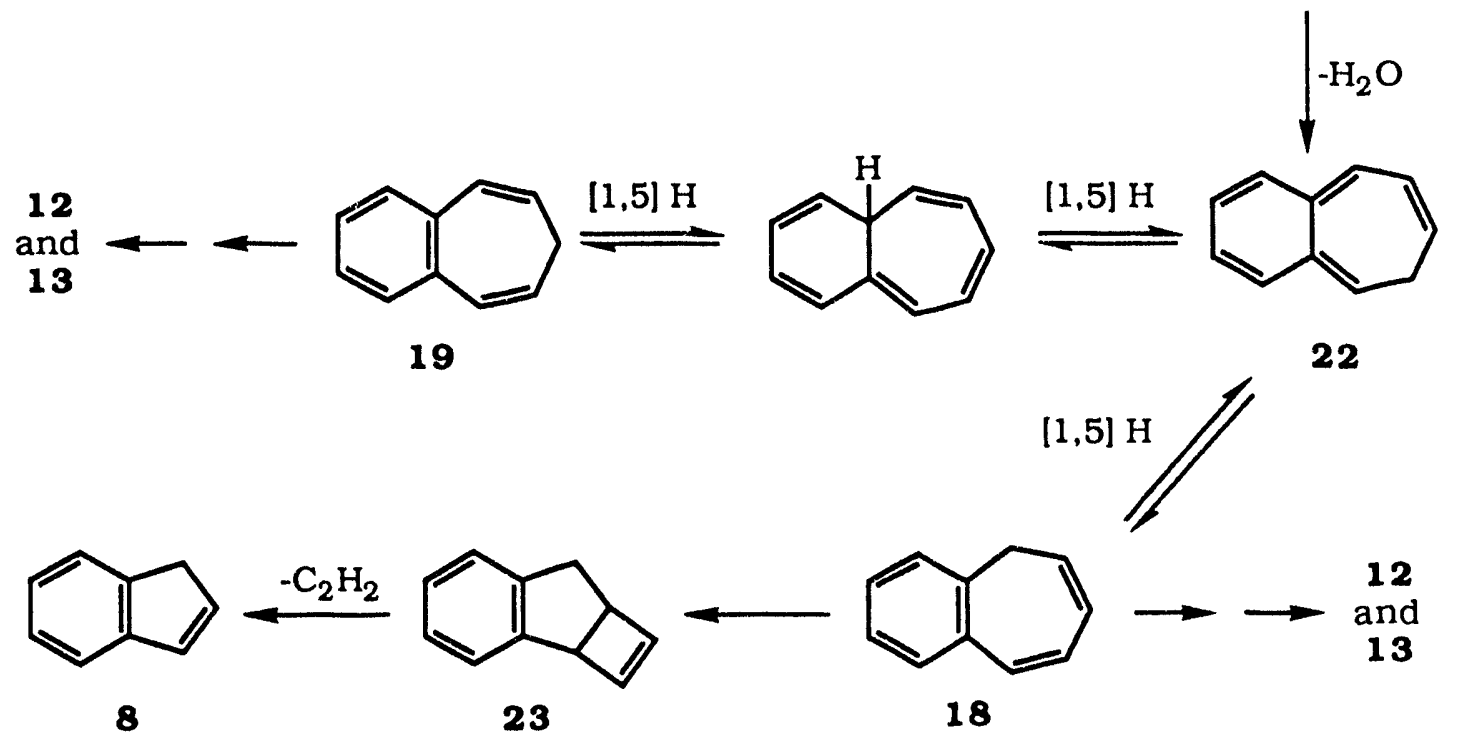




\section{CONCLUSION}

Several conclusions can be drawn from this study. First the thermal decomposition of ketone 10 in the gas-phase does produce diradical 9 but other reactions not involving 9 produce dehydration products $(12,13$, and other minor products), dehydrogenation products (2 and $\mathbf{5})$, and indene (8). Second, the major reaction in the photochemical decomposition of 10 at room temperature involves diradical 9. Third, the major pathway of the thermal decomposition of sulfone 11 in the gas-phase also involves diradical 9. Fourth, in all three cases presented here and in a previous study, 6 where 9 was produced from strained hydrocarbon 16, the major products were tetralin (1) and o-allyltoluene (4). The ratio of 1 to 4 increases with temperature and is between 1 and 8 to 1 over a temperature range of 25 to $950{ }^{\circ} \mathrm{C}$. Fifth, diradical 9 produces little or no dehydrogenation products (2 and 5 ) or ethylene-loss products (3 and 6). This conclusion supports the argument that ethylene loss from the thermal decomposition of tetralin (1) proceeds by a concerted mechanism and this argument has recelved support from other experiments. $2 n$ 


\section{EXPERIMENTAI}

\section{General Procedures}

\section{Methods and materials}

Some general methods have been described previously. 9 Photolysis was performed using a water-cooled $450 \mathrm{~W}$ medium pressure Conrad-Hanovia lamp. ${ }^{1} \mathrm{H}$ NMR spectra were recorded on a Nicolet NT-300 spectrometer. FTIR spectra were obtained on an IBM IR/98 or a Digllab FTS-7 spectrophotometer. GCMS were performed on a Finnegan 4000 mass spectrometer. HRMS were performed on a Kratos MS-50 mass spectrometer. All materials were commercially available and used as recetved, except where indicated.

\section{3-Benzocycloheptenone (10) 1-Methylene-1,2,3,4-tetrahydronaphthalene} was prepared by a modified literature procedure. ${ }^{10}$ Dry DMSO $(50 \mathrm{~mL})$ was added to $\mathrm{NaH}(4.0 \mathrm{~g}, 0.165 \mathrm{~mol})$ in a $250-\mathrm{mL}$ three-neck round-bottom flask fitted with a $125-\mathrm{mL}$ dropping funnel and condenser under $\mathrm{Ar}$ atmosphere with a magnetic stirrer. The solution was heated to $70-75^{\circ} \mathrm{C}$ for $1 \mathrm{~h}$ (until $\mathrm{H}_{2}$ evolution had ceased). DMSO (100 mL) was added to methyltriphenylphosphonium bromide $(53.6 \mathrm{~g}, 0.15 \mathrm{~mol})$ that was then heated to $\mathrm{ca} \cdot 70^{\circ} \mathrm{C}$ until the salt completely dissolved. This solution was transferred to the dropping funnel and was added dropwise to $\mathrm{NaCH}_{2} \mathrm{SOCH}_{3} / \mathrm{DMSO}$, forming a red-brown solution. After stirring for an additional $1 \mathrm{~h}$, l-tetralone (14.6 $\mathrm{g}, 0.10 \mathrm{~mol})$ was added dropwise with a syringe and the solution was stirred for $2 \mathrm{~h} . \mathrm{H}_{2} \mathrm{O}(250 \mathrm{~mL})$ was added to the reaction mixture that was then extracted with hexanes (4 $x 150 \mathrm{~mL}$ ). The combined hexanes portions was washed with $\mathrm{H}_{2} \mathrm{O}(2 \times 150 \mathrm{~mL})$ and dried $\left(\mathrm{MgSO}_{4}\right)$. The hexanes solution was filtered through neutral alumina to remove residual triphen- 
ylphosphine oxide and color. The solvent was removed in vacuo. The product was purified by flash chromatography on a sllica gel column $(50 \times 150 \mathrm{~mm}$ ) with hexanes to ydeld 1-methylene-1,2,3,4-tetrahydronaphthalene (13.5 g, $0.093 \mathrm{~mol}, 93 \%$ yield). bp 60$61{ }^{\circ} \mathrm{C}\left(0.8\right.$ torr) [1it. $\left.{ }^{11} 103^{\circ} \mathrm{C}(14 \mathrm{~mm})\right] ;{ }^{1} \mathrm{H} \mathrm{NMR}\left(\mathrm{CDCl}_{3}\right) \delta 7.66-7.63(\mathrm{~m}, 1 \mathrm{H}), 7.17-7.05$ (m, $3 \mathrm{H}$ ), 5.47 (br s, $1 \mathrm{H}$ ), 4.94 (d, $J=1.3 \mathrm{~Hz}, 1 \mathrm{H}), 2.84$ (t, $J=6.3 \mathrm{~Hz}, 2 \mathrm{H}$ ), 2.55 (pseudo t. $J=6.2 \mathrm{~Hz}, 2 \mathrm{H}$ ), 1.88 (quintet, $J=6.2 \mathrm{~Hz}, 2 \mathrm{H}$ ) [lit. $111_{\mathrm{H}}$ NMR (benzene-d6) $\delta$ 7.83-7.53 (m, $1 \mathrm{H}), 7.46-7.03$ (m, $3 \mathrm{H}), 5.50$ (br s, $1 \mathrm{H}), 4.96$ (br s, $1 \mathrm{H}), 3.00-1.60$ (m, $6 \mathrm{H})$ ): GCMS (EI, $70 \mathrm{eV}$ ) m/e (\% base peak) 144 (46.4), $129(100), 128$ (46.5), 115 (15.6).

The following procedure was adapted from the previously published procedure. 12 $\mathrm{AgNO}_{3}(4.7 \mathrm{~g}, 0.028 \mathrm{~mol})$ was added to a dry $500-\mathrm{mL}$ three-neck round-bottom flask fitted with a 125-mL pressure-equalizing dropping funnel and condenser under Ar. Dry $\mathrm{CH}_{3} \mathrm{OH}\left(2 \mathrm{Na}, 150 \mathrm{~mL}\right.$ ) was added to the $\mathrm{AgNO}_{3}$ and the solution was refluxed until the salt dissolved $(<1 \mathrm{~h})$. Care was taken to avoid exposure of this solution to light. $\mathrm{I}_{2}(3.6 \mathrm{~g}$, $0.014 \mathrm{~mol})$ was dissolved in dry $\mathrm{CH}_{3} \mathrm{OH}(2 \mathrm{Na}, 100 \mathrm{~mL})$. After the $\mathrm{AgNO}_{3}$ had dissolved, 1-methylene-1,2,3,4-tetrahydronaphthalene $(2.0 \mathrm{~g} .0 .014 \mathrm{~mol})$ was added to the $\mathrm{I}_{2}$ solution in $\mathrm{CH}_{3} \mathrm{OH}$. The stopper was removed from the dropping funnel and the alkene/I2 solution was immediately transferred ALL AT ONCE. The funnel was restoppered and the alkene/ $I_{2}$ solution was added RAPIDLY to the refluxing $\mathrm{AgNO}_{3}$ in $\mathrm{CH}_{3} \mathrm{OH}$ over a period of a few minutes with rapid stirring. After the addition was complete, the reaction mixture was refluxed for an additional $5 \mathrm{~h}$. When the solution had cooled to room temperature, the AgI was filtered off and washed with $\mathrm{CH}_{3} \mathrm{OH}(2 \times 25$ $\mathrm{mL}) . \mathrm{H}_{2} \mathrm{O}(150 \mathrm{~mL})$ and saturated $\mathrm{NaCl}(150 \mathrm{~mL})$ were added to the filtrate. The reaction mixture was extracted with ether $(4 \times 150 \mathrm{~mL})$ and the combined organic fractions was washed with $\mathrm{H}_{2} \mathrm{O}(2 \times 150 \mathrm{~mL})$ and saturated $\mathrm{NaCl}(150 \mathrm{~mL})$. The organic phase was drled $\left(\mathrm{MgSO}_{4}\right)$, concentrated, and the crude ketone was purffied by flash 
chromatography on a silica gel column $(50 \times 160 \mathrm{~mm})$ with $1: 9$ ethyl acetate to hexanes to yield 3-benzocycloheptenone (1.3 g. $8.2 \mathrm{mmol}, 59 \%$ yield). mp (2,4-DNP derivative) $170-170.3^{\circ} \mathrm{C}$ [lit. ${ }^{13} 169-170.5^{\circ} \mathrm{Cl}$; FTIR (KBr) 2941, 1713, 787, 756; $\left.{ }^{1} \mathrm{H} \mathrm{NMR} \mathrm{(CDCl}\right) \delta$ 7.23-7.15 (m, $4 \mathrm{H}$ ), 3.73 (s, $2 \mathrm{H}$ ), 2.95 (t, $J=6.3 \mathrm{~Hz}, 2 \mathrm{H}$ ), 2.57 (t, $J=6.9 \mathrm{~Hz}, 2 \mathrm{H}$ ), 1.99 (quintet, $J=6.6 \mathrm{~Hz}, 2 \mathrm{H}$ ) [lit. $131_{\mathrm{H} \mathrm{NMR}}\left(\mathrm{CDCl}_{3}\right) \delta 7.16(\mathrm{~s}, 4 \mathrm{H}), 3.7(\mathrm{~s}, 2 \mathrm{H}), 3.1-2.8$ (pseudo t, 2 H), 2.7-2.4 (pseudo t, $2 \mathrm{H}$ ), 2.2-1.6 (m, $2 \mathrm{H}$ )]; GCMS (EI, $70 \mathrm{eV}$ ) m/e (\% base peak) 160 (82.1), 105 (88.0), 104 (66.8), 55 (100).

\section{1,3,4,5-Tetrahydro-2-benzothiepin-2,2-diozide (11) 1,2-Dihydronaph-}

thalene $(2.6 \mathrm{~g}, 0.020 \mathrm{~mol})$ was dissolved in $\mathrm{CH}_{2} \mathrm{Cl}_{2}(100 \mathrm{~mL})$ and the solution was cooled to $-78{ }^{\circ} \mathrm{C}$. $\mathrm{O}_{3}\left(\mathrm{ca} .2 \%\right.$ in $\mathrm{O}_{2}$ ) was bubbled through the solution until a blue color developed. Excess $\mathrm{O}_{3}$ was then removed by bubbling $\mathrm{N}_{2}$ through the solution until the blue color had dissipated. The reaction mixture was warmed to room temperature and the solvent was removed in vacuo. The ozonide was dissolved in THF (15 mL) and added dropwise to a slurry of $\mathrm{LiAlH}_{4}(0.8 \mathrm{~g}, 0.022 \mathrm{~mol})$ in THF $(100 \mathrm{~mL})$ at $0^{\circ} \mathrm{C}$. After the addition was complete, the reaction mixture was stirred overnight at room temperature. A slurry of wet $\mathrm{Na}_{2} \mathrm{SO}_{4}$ was added to the reaction mixture until evolution of $\mathrm{H}_{2}$ ceased. The white solid was filtered off and washed with ethyl acetate. The filtrate was dried $\left(\mathrm{MgSO}_{4}\right)$ and the solvent was removed in vacuo. The crude diol was distilled at $150{ }^{\circ} \mathrm{C}$ (0.2 torr) to yield o-(3-hydroxypropyl)benzyl alcohol $(2.54 \mathrm{~g}, 0.015 \mathrm{~mol}, 75 \%$ yield). FTIR (thin film) $3375(\mathrm{br}), 2937,1032,758 ;{ }^{1} \mathrm{H} \mathrm{NMR}\left(\mathrm{CDCl}_{3}\right) 87.33-7.14(\mathrm{~m}, 4 \mathrm{H}), 4.67(\mathrm{~s}, 2 \mathrm{H})$, 3.50 (t, $J=6.0 \mathrm{~Hz}, 2 \mathrm{H}), 2.82$ (t, $J=6.9 \mathrm{~Hz}, 2 \mathrm{H}$ ), 1.90 (quintet, $J=6.6 \mathrm{~Hz}, 2 \mathrm{H}$ ).

Hydrobromic acid $(48 \%, 4 \mathrm{~mL}, 0.035 \mathrm{~mol})$ was added to 0 -(3-hydroxypropyl)benzyl alcohol $(0.62 \mathrm{~g} .3 .8 \mathrm{mmol})$ and the reaction mixture was heated to $100{ }^{\circ} \mathrm{C}$ for $8 \mathrm{~h}$. After it had cooled to room temperature, the reaction mixture was extracted with ether $(3 \times 20 \mathrm{~mL})$. The combined organic phases was washed with saturated 
$\mathrm{NaHCO}_{3}(20 \mathrm{~mL}), \mathrm{H}_{2} \mathrm{O}(20 \mathrm{~mL})$ and saturated $\mathrm{NaCl}(20 \mathrm{~mL})$. The organic phase was dried (MgSO 4$)$ and the solvent was removed in vacuo. The dibromide was purified by flash chromatography on a sllica gel column $(40 \times 80 \mathrm{~mm})$ with hexanes to yield o-(3-bromopropyl)benzyl bromide $\left(0.88 \mathrm{~g}, 3.0 \mathrm{mmol}, 79 \%\right.$ yield). ${ }^{1} \mathrm{H}$ NMR $\left(\mathrm{CDCl}_{3}\right) \delta 7.37-$ 7.20 (m, $4 \mathrm{H}$ ), 4.56 (s, $2 \mathrm{H}$ ), 3.48 (t, $J=6.8 \mathrm{~Hz}, 2 \mathrm{H}$ ), 2.91 (t, $J=7.2 \mathrm{~Hz}, 2 \mathrm{H}$ ), 2.29-2.18 (m, 2 H): GCMS (EI, $70 \mathrm{eV}$ ) m/e (\% base peak) 294 (3.1), 292 (6.0), 290 (2.8), 213 (49.5), 211 (52.9), 131 (84.9), $105(100)$.

$\mathrm{Na}_{2} \mathrm{~S} \cdot 9 \mathrm{H}_{2} \mathrm{O}(0.82 \mathrm{~g}, 3.4 \mathrm{mmol})$ was dissolved in absolute ethanol $(500 \mathrm{~mL})$. Five portions of o-(3-bromopropyl)benzyl bromide $(50 \mathrm{mg}, 0.17 \mathrm{mmol}, \mathrm{ca} .30 \mu \mathrm{L}$ ) were added at $1 \frac{1}{2} \mathrm{~h}$ intervals and then the reaction mixture was stirred overnight. ${ }^{14}$ This procedure was repeated with five additional portions of dibromide. After the reaction mixture was again stirred overnight. most of the ethanol (ca. $450 \mathrm{~mL}$ ) was removed by distillation. $\mathrm{H}_{2} \mathrm{O}(100 \mathrm{~mL})$ was added to the residue that was then extracted with ether $(3 \times 50 \mathrm{~mL})$. The combined organic layers was washed with $\mathrm{H}_{2} \mathrm{O}(2 \times 50 \mathrm{~mL})$ and saturated $\mathrm{NaCl}(50$ $\mathrm{mL})$, then dried $\left(\mathrm{MgSO}_{4}\right)$. The solvent was removed in vacuo and the crude product was purified by flash chromatography on a silica gel column $(30 \times 150 \mathrm{~mm})$ with $5: 1$ hexanes to $\mathrm{CH}_{2} \mathrm{Cl}_{2}$ to yield 1.3.4.5-tetrahydro-2-benzothiepin $(0.18 \mathrm{~g}, 1.1 \mathrm{mmol}, 65 \%$ yield). $\mathrm{mp}$ $46-48^{\circ} \mathrm{C}$ [lit. ${ }^{15} 49-50{ }^{\circ} \mathrm{C}$ ): FTIR (thin film) 3014, 2937, 2918, 2842, 1449, 747; ${ }^{1} \mathrm{H}$ NMR $\left(\mathrm{CDCl}_{3}\right) 87.15-7.10(\mathrm{~m}, 4 \mathrm{H}), 3.83(\mathrm{~s}, 2 \mathrm{H}), 2.86-2.95(\mathrm{~m}, 4 \mathrm{H}), 2.03-1.94(\mathrm{~m}, 2 \mathrm{H})\left[1 \mathrm{lt} .15 \mathrm{l}_{\mathrm{H}}\right.$ NMR (CDCl 3 ) $\delta 7.04$ (m, 4 H), 3.76 (s, $2 \mathrm{H}), 2.85$ (t, $J=6 \mathrm{~Hz}, 2 \mathrm{H}), 1.75$ (t, $2 \mathrm{H}), 1.15$ (m, 2 H)I: GCMS (EI. $70 \mathrm{eV}$ ) m/e (\% bas: peak) 164 (100), 131 (51.9), 117 (46.5), 115 (37.9), 91 (32.0).

1.3.4.5-Tetrahydro-2-benzothlepin $(0.18 \mathrm{~g}, 1.1 \mathrm{mmol})$ was dissolved in $\mathrm{CH}_{2} \mathrm{Cl}_{2} \mathrm{C}_{5}$ $\mathrm{mL})$. m-CPBA (80\%, $0.52 \mathrm{~g}, 2.4 \mathrm{mmol})$ was added and the reaction mixture was stirred overnight. The reaction mixture was washed with saturated sodium bisulfite $(10 \mathrm{~mL}), 1$ 
$\mathrm{M} \mathrm{KOH}(3 \times 10 \mathrm{~mL})$ and $\mathrm{H}_{2} \mathrm{O}(10 \mathrm{~mL})$ and then dried $\left(\mathrm{MgSO}_{4}\right)$. The solvent was removed in vacuo to yield 1,3,4,5-tetrahydro-2-benzothiepin-2,2-dioxide $10.21 \mathrm{~g}, 1.1 \mathrm{mmol}, 100 \%$ yield). mp 179-180 ${ }^{\circ} \mathrm{C}$ (dec); FTIR (thin film) 2973, 2916, 2861, 1284, 1254, 1110, 858 , 781, 750; ${ }^{1} \mathrm{H} \mathrm{NMR}\left(\mathrm{CDCl}_{3}\right) \delta 7.33-7.15(\mathrm{~m}, 4 \mathrm{H}), 4.39$ (s, $\left.2 \mathrm{H}\right), 3.28$ (t, $J=6.0 \mathrm{~Hz}, 2 \mathrm{H}$ ), 3.01-2.95 (m, 2 H), 2.25-2.15 (m, 2 H); GCMS (EI, $70 \mathrm{eV}) \mathrm{m} / \mathrm{e}$ (\% base peak) 196 (18.7). 132 (16.0), 104 (100), 91 (26.8); HRMS (EI, $70 \mathrm{eV}$ ) calculated for $\mathrm{C}_{10} \mathrm{H}_{12} \mathrm{O}_{2} \mathrm{~S}, 196.05580$; measured, 196.05604 (error $+1.21 \mathrm{ppm})$.

Flash vacuum pyrolysis Flash vacuum pyrolysis (FVP) was performed as previously described. 16

Flow pyrolysis Flow pyrolysis was performed on the same apparatus described previously 5 a except that the sample inlet was modified. An attachment was made that consisted of a Pyrex tube with 24/40 inner and outer joints attached to each end. The attachment also had glass tube that extended below the inner joint and passed through the side wall to a ground glass stopcock. The attachment was placed on the sample inlet of the flow pyrolysis apparatus and the sample, in a round-bottom flask, was placed on the other end of the attachment. After the usual degassing, Ar was flowed over the sample through the side tube on the attachment. The sample temperature was maintained for the entire pyrolysis time with a thermostatic oil bath. Other aspects of the flow pyrolysis were as previously described. $5 a$

Photolysis 3-Benzocycloheptenone $(10,32 \mathrm{mg}, 0.20 \mathrm{mmol})$ was dissolved in $550 \mathrm{~mL}$ of spectrophotometric grade pentanes and $50 \mathrm{~mL}$ methanol. After deæration for $2 \mathrm{~h}$ with $\mathrm{Ar}$, the sample was photolyzed for $2 \mathrm{~h}$ with a Pyrex filter $(\lambda>280 \mathrm{~nm})$. The solution was extracted with $\mathrm{H}_{2} \mathrm{O}(500 \mathrm{~mL})$, saturated $\mathrm{NaCl}(500 \mathrm{~mL})$, and dried $\left(\mathrm{MgSO}_{4}\right)$. The pentanes was removed by distillation until a few milliliters of solution remained. The 
reaction mixture was analyzed as described below after $1 \mathrm{~mL}$ of $c a .5 \mathrm{mg} \mathrm{mL}^{-1}$ solution of biphenyl in $\mathrm{CH}_{2} \mathrm{Cl}_{2}$ was added.

Product analysis FVP and flow pyrolysis reaction mixtures were analyzed by caplllary gas chromatography on a Hewlett-Packard HP5840A gas chromatograph equipped with a 30-m (0.25- $\mu \mathrm{m}$ film thickness) DB-1701 capillary column using the analytical procedure previously described. $5 a$ Photolysis reaction mixtures were analyzed on a Hewlett-Packard HP5890 gas chromatograph equipped with a 30-m $10.25-\mu \mathrm{m}$ film thickness) DB-1 captllary column following the same analytical procedure used for FVP and flow pyrolysis reaction mixtures. 


\section{REFERENCES}

(1) Poutsma, M. L. A Review of Thermolysis Studies of Model Compounds Relevant to Processing of Coal; ORNL/TM-10673, Oak Ridge National Laboratory. Oak Ridge. TN 37831. This review is avallable from National Technical Information Service, U. S. Dept. of Commerce, 5285 Port Royal Rd., Springfield, VA 22161.

(a) Badger, G. M.; Kimber, R. W. L. J. Chem. Soc. 1960, 266. (b) Badger, G. M.; Kimber, R. W. L.; Novotny, J. Aust. J. Chem. 1962, 15, 616. (c) Loudon, A. G.; Maccoll, A.; Wong, S. K. J. Chem. Soc. B 1970, 1733. (d) Penninger, J. M. L.; Slotboom, H. W. Recl. Trav. Chim. Pays-bays 1973, 92, 513. (e) Penninger, J. M. L.; Slotboom, H. W. Ibid. 1973, 92, 1089. (f) Tominaga, H.; Yahagi, U. J. Fac. Eng., Univ. Tokyo, Ser. A 1977, 15, 68. (g) Bredael, P.; Vinh, T. H. Fuel 1979, 58. 211. (h) Gangwer, T.: MacKenzie, D.: Casano, S. J. Phys. Chem. 1979, 83, 2013. (1) Berman, M. R. Comita, P. B.; Moore, C. B.; Bergman, R. G. J. Amer. Chem. Soc. 1980, 102, 5692. (j) Cyprès, R, Bredael, P. Fuel Process. Tech. 1980, 3, 297. (k) Trushkova, L. V.; Magaril, R. Z.; Korzun, N. V.; Bulatov, R. A. Russ. J. Phys. Chem. 1980, 54, 1062. (l) Cornita, P. B.; Berman, M. R.; Moore, B. C.; Bergman, R. G. J. Phys. Chem. 1981, 85, 3266. (m) Takahash1, K.; Ogino, Y. Fuel 1981, 60. 975. (n) Trahanovsky, W. S.; Swenson, K. E. J. Org. Chem. 1981, 46, 2984. (o) Bajus, M.; Baxa. J. Coll. Czech. Chem. Commun. 1982, 47, 1838. (p) Penninger, J. M. L. Int. J. Chem. Kinetics 1982, 14, 761. (q) Hillebrand, W.; Hodek, W.; Kölling, G. Fuel 1984, 63, 756. (r) Korzun, N. V.; Trushkova, L. V. Kinetics Catal. 1985. 26. 195. (s) Tsang, W.; Cui, J. P. J. Amer. Chem. Soc. 1990, 112, 1665.

(3) In the liquid-phase pyrolysis of 1, the major ring-contracted product has been identified as 1 -methylindan, ${ }^{4}$ but we have conclusively identified the major methylindan in gas-phase pyrolysis of 1 as the 2-methyl isomer (7). Some workers have incorrectly reported 1-methylindan as the gas-phase pyrolysis product. 2 d,e.p

(4) Benjamin, B. M.; Hagaman, E. W.: Raaen, V. F.; Collins, C. J. Fuel 1979, 58, 386.

(5) (a) Malandra, J. L.; Zhu, J.; Lee, S.-K.; Spurlin, S. R.; Tunkel, J. L.; Fischer, D. R.; Yeung, E. S.; Trahanovsky, W. S., manuscript in preparation. [Paper 1, this dissertation] (b) Trahanovsky, W. S.; Malandra, J. L.: Ferguson, J. M. J. Amer. Chem. Soc. 1993, 115, 0000. [Paper 5, this dissertation]

(6) Gajewskd, J. J.; Paul, G. C. J. Org. Chem. 1990, 55, 4575. 
(7) (a) Cristol, S. J.; Caple, R. J. Org. Chem. 1966, 31, 585. (b) Scott, L. T.; Erden, I. J. Amer. Chem. Soc. 1982, 104, 1147. (c) Brinker, U. H.; Wilk, G.; Gomann, K. Angew. Chem. 1983, 95, 892; Angew. Chem. Int. Ed. Engl. 1983, 22, 868.

(8) Bond energies in kcal mol-1 for: $\mathrm{PhCH}_{2}-\mathrm{SO}_{2} \mathrm{CH}_{3}, 52.9 ; \mathrm{PhCH}_{2}-\mathrm{COCH}_{2} \mathrm{Ph}, 65.4$. From CRC Handbook of Chemistry and Physics, 66th Edition; Weast, R. C., Ed.; CRC Press, Inc.: Boca Raton, FL, 1985.

(9) (a) Trahanovsky, W. S.; Cassady, T. J.; Woods, T. L. J. Amer. Chem. Soc. 1981, 103, 6691. (b) Chou, C.-H.; Trahanovsky, W. S. J. Amer. Chem. Soc. 1986, 108. 4138.

(10) Greenwald, R.; Chaykovsky, M.: Corey, E. J. J. Org. Chem. 1963, 28, 1128.

(11) Meyers, A. I.; Ford, M. E. J. Org. Chem. 1976, 41, 1735.

(12) El-HossinI, M. S.; McCullough, K. J.; McKay, R.; Proctor, G. R. Tetrahedron Lett. 1986, 27, 3783 .

(13) Fristad, W. E.; Bailey. T. R.; Paquette, L. A. J. Org. Chem. 1980, 45, 3028.

(14) It was necessary to do this procedure at high dilution. At higher concentrations, sulfide dimer 25 was formed. We oxidized 25 to sulfone dimer 26.<smiles>c1ccc2c(c1)CCCSCc1ccccc1CCCSC2</smiles>

25<smiles>O=S(=O)(CCCc1ccccc1CS(=O)(=O)OCCCc1ccccc1)OCCO</smiles>

26

1,8-Dithia-3,10-dibenzocyclotetradecadiene (25). $\mathrm{mp} 142-143{ }^{\circ} \mathrm{C}$; FTIR (thin film) $2920,1489,1462,1259,1047,748,708:{ }^{1} \mathrm{H} \mathrm{NMR}\left(\mathrm{CDCl}_{3}\right) \delta 7.35-$ 7.30 (m, $2 \mathrm{H}), 7.23-7.11(\mathrm{~m}, 6 \mathrm{H}), 3.96$ (s, $4 \mathrm{H}), 2.87-2.80(\mathrm{~m}, 4 \mathrm{H}), 2.72-2.65$ (t, $J=$ $6 \mathrm{~Hz}, 4 \mathrm{H}), 2.06-1.95(\mathrm{~m}, 4 \mathrm{H}) ; \mathrm{MS}(\mathrm{EI}, 70 \mathrm{eV}) \mathrm{m} / e$ (\% base peak) $328(52.5), 164$ (100), 163 (59.8), 162 (42.7), 131 (48.4), 130 (36.5), 129 (37.4), 117 (33.8), 115 (30.3), 105 (38.9), 91 (40.3).

1,8-Dithia-3,10-dibenzocyclotetradecadiene-1,1,8,8-tetroxide (26).

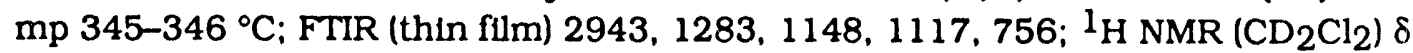
7.65-7.61 (m, $2 \mathrm{H}), 7.40-7.26(\mathrm{~m}, 6 \mathrm{H}), 4.73(\mathrm{~s}, 4 \mathrm{H}), 3.17-3.11(\mathrm{~m}, 4 \mathrm{H}), 3.00(\mathrm{t}, J=$ $6 \mathrm{~Hz}, 4 \mathrm{H}), 2.37-2.25(\mathrm{~m}, 4 \mathrm{H})$; MS (EI, $70 \mathrm{eV}$ m/e (\% base peak) 392 (1.4), 328 (30.9), 144 (27.0), 131 (100), 117 (30.3), 104 (49.5), 91 (38.4). 
(15) Pellicclari, R.; Natalini, B. J. Chem. Soc., Perkin Trans. 1 1977, 1822.

(16) (a) Trahanovsky, W. S.; Ong, C. C.; Pataky, J. G.; Weltl, F. L.; Mullen, P. W.; Clardy, J. C.; Hansen, R. S. J. Org. Chem. 1971, 36, 3575. Commercial apparatus is avallable from Kontes Scientific Glassware, Vineland, NJ 08360. (b) For review, see Brown, R. C. F. Pyrolysis Methods in Organic Chemistry: Academlc: New York, 1980, Chapter 2. 


\section{APPENDIX 1}

\section{SUPPLEMENTARY DATA TABLES}

Table A-I. Products and recovered starting material, total recovery of material, and conversion from the FVP of 3-benzocycloheptenone (10) at various oven temperatures $a, b$

\begin{tabular}{|c|c|c|c|c|c|}
\hline \multirow[b]{2}{*}{ entry } & \multicolumn{5}{|c|}{ yield, $\% c$} \\
\hline & $700^{\circ} \mathrm{C}$ & $750^{\circ} \mathrm{C}$ & $800^{\circ} \mathrm{C}$ & $850^{\circ} \mathrm{C}$ & $900^{\circ} \mathrm{C}$ \\
\hline toluene & - & - & - & - & 1.46 \\
\hline ethylbenzene & - & - & 0.28 & 0.68 & 1.34 \\
\hline o-xylene & - & - & 0.36 & 1.15 & 2.68 \\
\hline styrene (6) & - & 0.15 & 0.40 & 1.10 & 4.04 \\
\hline benzocyclobutene (3) & - & 0.11 & 0.71 & 2.05 & 4.17 \\
\hline o-ethyltoluene & - & - & 0.42 & 1.33 & 1.53 \\
\hline o-methylstyrene & - & - & - & - & 0.96 \\
\hline o-allyltoluene (4) & 一 & 0.17 & 0.85 & 1.76 & 1.92 \\
\hline indene (8) & 0.17 & 0.71 & 3.32 & 8.15 & 15.28 \\
\hline 2-methylindan (7) & - & - & 0.21 & 0.83 & 1.60 \\
\hline $\mathrm{TD}-130\left[\mathrm{C}_{10} \mathrm{H}_{10}\right]$ & - & - & - & - & 0.29 \\
\hline o-(1-propenyl)toluene & - & - & - & - & 0.45 \\
\hline 3-methyl-1H-indene & - & 0.12 & 0.26 & 0.51 & 0.93 \\
\hline tetralin (1) & 0.25 & 1.09 & 6.49 & 14.88 & 19.93 \\
\hline 2-methyl-1H-indene & - & - & 0.15 & - & 0.50 \\
\hline $\mathrm{TK}-130\left[\mathrm{C}_{10} \mathrm{H}_{10}\right]$ & - & - & 0.28 & 0.63 & 0.81 \\
\hline
\end{tabular}

Table A-I continues on next page 
Table A-I. Continued

\begin{tabular}{|c|c|c|c|c|c|}
\hline \multirow[b]{2}{*}{ entry } & \multicolumn{5}{|c|}{ yield, \% c } \\
\hline & $700^{\circ} \mathrm{C}$ & $750^{\circ} \mathrm{C}$ & $800^{\circ} \mathrm{C}$ & $850^{\circ} \mathrm{C}$ & $900^{\circ} \mathrm{C}$ \\
\hline 1,2-dihydronaphthalene (2) & 0.68 & 1.34 & 3.41 & 5.71 & 5.58 \\
\hline$T L-128\left[\mathrm{C}_{10} \mathrm{H}_{8}\right]$ & - & - & - & - & 0.22 \\
\hline naphthalene (5) & 0.36 & 0.64 & 2.20 & 4.72 & 10.24 \\
\hline $\left.\mathrm{KA}-142\left[\mathrm{C}_{1}\right]_{10} \mathrm{H}_{10}\right]$ & 1.47 & 1.10 & 1.14 & 0.59 & 0.24 \\
\hline $\mathrm{KB}-142\left[\mathrm{C}_{1} \mathrm{H}_{1 \mathrm{O}}\right]$ & 0.20 & 0.32 & 0.66 & 0.58 & 0.29 \\
\hline $\mathrm{KC}-142\left[\mathrm{C}_{11} \mathrm{H}_{10}\right]$ & 0.74 & 0.50 & 0.49 & - & - \\
\hline 2-methylnaphthalene (13) & 0.63 & 1.06 & 3.12 & 3.47 & 3.04 \\
\hline 1-methylnaphthalene (12) & 1.47 & 2.62 & 8.09 & 8.41 & 6.64 \\
\hline $\mathrm{KD}-142\left[\mathrm{C}_{11} \mathrm{H}_{10} \mathrm{O}\right]$ & - & - & 0.27 & 0.35 & 0.21 \\
\hline $\mathrm{KE}-142\left[\mathrm{C}_{11} \mathrm{H}_{10} \mathrm{O}\right.$ & - & - & 0.37 & 0.56 & 0.49 \\
\hline $\mathrm{KF}-160\left[\mathrm{C}_{11} \mathrm{H}_{12} \mathrm{O}\right]$ & - & 0.07 & 0.11 & - & - \\
\hline $\mathrm{KG}-160\left[\mathrm{C}_{11} \mathrm{H}_{12} \mathrm{O}\right]$ & - & 0.08 & 0.11 & - & - \\
\hline $\mathrm{KH}-146\left[\mathrm{C}_{10} \mathrm{H}_{10} \mathrm{O}\right]$ & 0.19 & 0.19 & 0.12 & - & - \\
\hline $\mathrm{KI}-160\left[\mathrm{C}_{11} \mathrm{H}_{12} \mathrm{O}\right]$ & 0.11 & 0.27 & 0.75 & 1.06 & 0.63 \\
\hline $\mathrm{KJ}$ & $d$ & $d$ & - & - & - \\
\hline 3-benzocycloheptenone (10) & 93.26 & 88.55 & 63.57 & 38.55 & 11.90 \\
\hline $\mathrm{KK}-160\left[\mathrm{C}_{11} \mathrm{H}_{12} \mathrm{O}\right]$ & 0.14 & 0.35 & 1.15 & 1.81 & 1.49 \\
\hline $\mathrm{KL}-160\left[\mathrm{C}_{11} \mathrm{H}_{12} \mathrm{O}\right]$ & 0.33 & 0.47 & 0.38 & 0.32 & 0.09 \\
\hline $\mathrm{KM}$ & - & - & - & - & $d$ \\
\hline $\mathrm{KN}-144\left[\mathrm{C}_{10} \mathrm{H}_{8} \mathrm{O}\right]$ & - & 0.09 & 0.32 & 0.87 & 1.11 \\
\hline KO & - & - & - & - & $d$ \\
\hline KP & $d$ & $d$ & $d$ & - & - \\
\hline
\end{tabular}

Table A-I continues on next page 
Table A-I. Continued

\begin{tabular}{|c|c|c|c|c|c|}
\hline \multirow[b]{2}{*}{ entry } & \multicolumn{5}{|c|}{ yield, $\% c$} \\
\hline & $700^{\circ} \mathrm{C}$ & $750^{\circ} \mathrm{C}$ & $800^{\circ} \mathrm{C}$ & $850^{\circ} \mathrm{C}$ & $900^{\circ} \mathrm{C}$ \\
\hline $\mathrm{KQ}$ & - & - & $d$ & - & $d$ \\
\hline recovery $e$ & 90.07 & 83.73 & 84.03 & 78.40 & 66.67 \\
\hline conversion $f$ & 6.74 & 11.45 & 36.43 & 61.47 & 88.10 \\
\hline \multicolumn{6}{|c|}{ 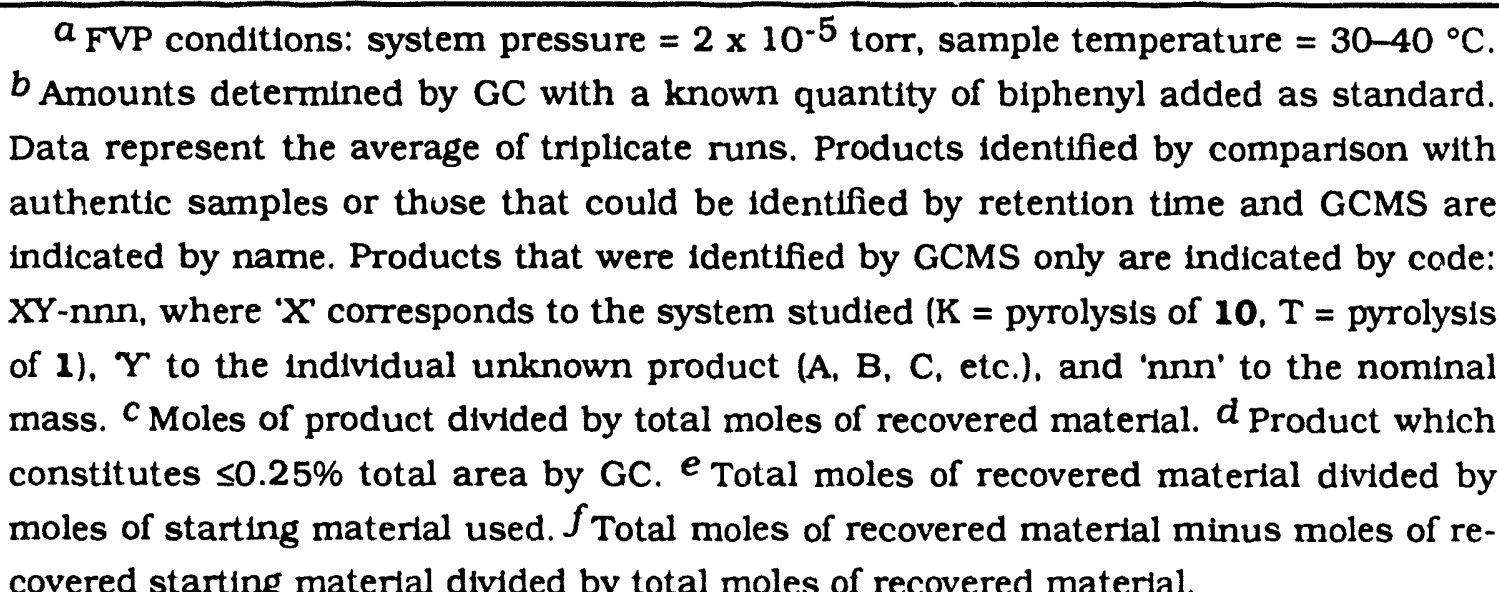 } \\
\hline
\end{tabular}


Table A-I. Products and recovered starting material, total recovery of material, and conversion from the flow pyrolysis of 3-benzocycloheptenone (10) at various oven temperatures $a, b$

\begin{tabular}{|c|c|c|c|c|}
\hline \multirow[b]{2}{*}{ entry } & \multicolumn{4}{|c|}{ yield, $\% c$} \\
\hline & $754^{\circ} \mathrm{C}$ & $800^{\circ} \mathrm{C}$ & $851^{\circ} \mathrm{C}$ & $900^{\circ} \mathrm{C}$ \\
\hline toluene & - & - & - & 0.56 \\
\hline ethylbenzene & - & - & - & 0.29 \\
\hline o-xylene & - & - & 0.22 & 0.82 \\
\hline styrene (6) & - & 一 & 0.36 & 4.12 \\
\hline benzocyclobutene (3) & - & 0.54 & 1.69 & 7.98 \\
\hline o-ethyltoluene & - & - & - & 0.52 \\
\hline benzaldehyde & - & - & - & 0.33 \\
\hline o-allyltoluene (4) & 0.58 & 0.95 & 2.13 & 3.87 \\
\hline indene $(8)$ & 0.40 & 1.29 & 4.15 & 10.43 \\
\hline 2-methylindan (7) & - & - & 0.70 & 2.57 \\
\hline TD- $130\left[\mathrm{C}_{10} \mathrm{H}_{10}\right]$ & - & - & - & 0.60 \\
\hline$o-(1-$ propenyl)toluene & 一 & 0.57 & 0.92 & 0.81 \\
\hline $\mathrm{TH}-130\left[\mathrm{C}_{10} \mathrm{H}_{10} \mathrm{l}\right.$ & - & 一 & - & 0.94 \\
\hline tetralin (1) & 2.08 & 6.28 & 18.74 & 29.26 \\
\hline 1,2-dihydronaphthalene (2) & 0.95 & 1.09 & 2.45 & 3.19 \\
\hline naphthalene (5) & 0.70 & 0.76 & 2.01 & 3.74 \\
\hline slloxane $\left(\left(\mathrm{CH}_{3}\right)_{2} \mathrm{SlO}_{6}\right.$ & - & - & $d$ & - \\
\hline $\mathrm{KA}-142\left[\mathrm{C}_{11} \mathrm{H}_{1 \mathrm{O}}\right]$ & 0.50 & 0.36 & 0.30 & - \\
\hline $\mathrm{KB}-142\left[\mathrm{C}_{11} \mathrm{H}_{10} \mathrm{O}\right.$ & - & 0.31 & 0.40 & 0.37 \\
\hline 2-methylnaphthalene (13) & 0.75 & 1.37 & 3.20 & 3.59 \\
\hline 1-methylnaphthalene (12) & 1.91 & 3.48 & 7.85 & 8.63 \\
\hline
\end{tabular}

Table A-II continues on next page 
Table A-II. Continued

\begin{tabular}{lcccc}
\hline & \multicolumn{4}{c}{ yield, \% } \\
\cline { 2 - 5 } entry & $754{ }^{\circ} \mathrm{C}$ & $800^{\circ} \mathrm{C}$ & $851^{\circ} \mathrm{C}$ & $900{ }^{\circ} \mathrm{C}$ \\
\hline $\mathrm{KD}-142\left[\mathrm{C}_{11} \mathrm{H}_{10}\right]$ & - & - & 0.28 & 0.60 \\
$\mathrm{KF}-160\left[\mathrm{C}_{11} \mathrm{H}_{12} \mathrm{O}\right]$ & - & 0.17 & 0.48 & 1.56 \\
$\mathrm{KH}-146\left[\mathrm{C}_{10} \mathrm{H}_{10} \mathrm{O}\right]$ & 0.50 & 0.50 & 0.41 & 0.13 \\
$\mathrm{KI}-160\left[\mathrm{C}_{11} \mathrm{H}_{12} \mathrm{O}\right]$ & 0.31 & 0.76 & 1.03 & 0.60 \\
3 -benzocycloheptenone & 90.15 & 79.79 & 49.76 & 12.22 \\
$\mathrm{KK}-160\left[\mathrm{C}_{11} \mathrm{H}_{12} \mathrm{O}\right]$ & 0.73 & 1.32 & 2.64 & 2.61 \\
$\mathrm{KL}-160\left[\mathrm{C}_{11} \mathrm{H}_{12} \mathrm{O}\right]$ & 0.44 & 0.45 & 0.27 & - \\
& & & & \\
recovery $e$ & 54.04 & 50.36 & 52.26 & 45.87 \\
conversion $f$ & 9.85 & 20.21 & 50.24 & 87.78 \\
\hline
\end{tabular}

$a_{\text {Flow pyrolysis conditions: system pressure }=0.010 \text { torr, sample temperature }=26}$ ${ }^{\circ} \mathrm{C}$. flow rate $=450 \mathrm{~mL} \mathrm{~min}-1(\mathrm{Ar} / 1 \mathrm{~atm})$ for $10 \mathrm{~h}$, residence time $=0.28 \mathrm{~s}$. ${ }^{b}$ See Table A-I, footnote $b$. $c$ See Table A-I, footnote $c$. $d$ Product which constitutes $\leq 0.50 \%$ total area by GC. $e$ See Table A-I, footnote $e . f$ See Table A-I, footnote $f$. 
Table A-II. Products and recovered starting material, total recovery of material, and conversion from the photolysis of 3-benzocycloheptenone (10) $a, b$

\begin{tabular}{lclc}
\hline entry & yield, \%c & entry & yield, \% $c$ \\
\hline LA-142 $\left[\mathrm{C}_{11} \mathrm{H}_{12}\right]$ & 0.12 & $\mathrm{LH}-192\left[\mathrm{C}_{12} \mathrm{H}_{16} \mathrm{O}_{2}\right](14)$ & 1.44 \\
LB-142 $\left[\mathrm{C}_{11} \mathrm{H}_{12}\right]$ & 0.58 & $\mathrm{LI}-160\left[\mathrm{C}_{11} \mathrm{H}_{12} \mathrm{O}\right]$ & 0.65 \\
LC-142 $\left[\mathrm{C}_{11} \mathrm{H}_{12}\right]$ & 0.35 & $\mathrm{~L}-160\left[\mathrm{C}_{11} \mathrm{H}_{12} \mathrm{O}\right]$ & 0.49 \\
LD-142 $\left[\mathrm{C}_{11} \mathrm{H}_{12}\right]$ & 0.39 & $\mathrm{LK}$ & $d$ \\
O-allyltoluene (4) & 2.67 & $\mathrm{LL}$ & $d$ \\
LE & $d$ & $\mathrm{LM}$ & $d$ \\
tetralin $(1)$ & 8.06 & $\mathrm{LN}$ & $d$ \\
LF-160 $\left[\mathrm{C}_{11} \mathrm{H}_{12} \mathrm{O}\right]$ & 0.67 & & \\
LG-160 $\left[\mathrm{C}_{11} \mathrm{H}_{12} \mathrm{O}\right]$ & 0.38 & recovery $e$ & 72.38 \\
3-benzocycloheptenone (10) & 84.20 & conversion $f$ & 15.80 \\
\hline
\end{tabular}

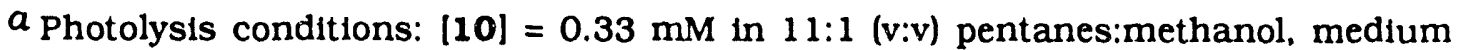
pressure $\mathrm{Hg}$ lamp with Pyrex filter $(\lambda>280 \mathrm{~nm}), 2 \mathrm{~h}$ at room temperature. ${ }^{b}$ Amounts determined by GC with a known quantity of biphenyl added as standard. Data represent the average of triplicate runs. Products identified by comparison with authentic samples or those that could be identified by retention time and GCMS are indicated by name. Products that were identified by GCMS only are indicated by code: XY-nnn, where ' $\mathrm{X}$ ' corresponds to the system studied $(\mathrm{L}=$ photolysis of 10$), \mathrm{Y}$ to the individual unknown product (A, B, C, etc.), and 'nnn' to the nominal mass. ${ }^{c}$ See Table A-I, footnote $c . d$ Product which constitutes $\leq 0.75 \%$ total area by GC. ${ }^{e}$ See Table A-I, footnote e. $f$ See Table A-I, footnote $f$. 
Table A-IV. Products and recovered starting material, total recovery of material, and conversion from the FVP of 1,3,4,5-tetrahydro-2-benzothiepin-2,2-dioxdde (11) at various oven temperatures $a, b$

\begin{tabular}{|c|c|c|c|c|}
\hline \multirow[b]{2}{*}{ entry } & \multicolumn{4}{|c|}{ yield, $\% c$} \\
\hline & $600^{\circ} \mathrm{C}$ & $700^{\circ} \mathrm{C}$ & $800^{\circ} \mathrm{C}$ & $900^{\circ} \mathrm{C}$ \\
\hline ethylbenzene & - & - & 0.32 & 0.52 \\
\hline o-xylene & - & - & 0.14 & 0.42 \\
\hline styrene (6) & 0.25 & 0.58 & 0.45 & 3.61 \\
\hline benzocyclobutene (3) & 0.29 & 1.13 & 2.07 & 7.79 \\
\hline siloxane $\left(\left(\mathrm{CH}_{3}\right)_{2} \mathrm{SiO}_{4}\right.$ & - & - & $d$ & - \\
\hline o-methylstyrene & - & - & 0.13 & 0.49 \\
\hline o-allyltoluene (4) & 2.04 & 12.48 & 11.34 & 5.40 \\
\hline indene (8) & - & 0.13 & 0.61 & 4.43 \\
\hline 2-methylindan (7) & - & 0.17 & 2.60 & 5.25 \\
\hline siloxane $\left(\left(\mathrm{CH}_{3}\right)_{2} \mathrm{SIO}_{5}\right.$ & $d$ & $d$ & - & - \\
\hline o-(1-propenyl)toluene & - & - & 0.21 & 1.13 \\
\hline tetralin (1) & 13.18 & 75.77 & 79.10 & 62.53 \\
\hline 2-methyl-1H-indene & - & - & - & 0.36 \\
\hline 1,2-dihydronaphthalene (2) & 0.28 & 0.94 & 1.98 & 3.44 \\
\hline naphthalene (5) & - & 0.27 & 0.91 & 4.63 \\
\hline sllaxane $\left(\left(\mathrm{CH}_{3}\right)_{2} \mathrm{SIO}_{6}\right.$ & $d$ & $d$ & $d$ & - \\
\hline SA & - & $d$ & - & - \\
\hline SB & - & $d$ & - & - \\
\hline SC & - & $d$ & $d$ & - \\
\hline SD & - & - & $d$ & - \\
\hline SE & - & $d$ & - & - \\
\hline
\end{tabular}

Table A-IV continues on next page 


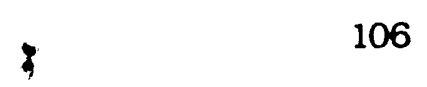

Table A-IV. Continued

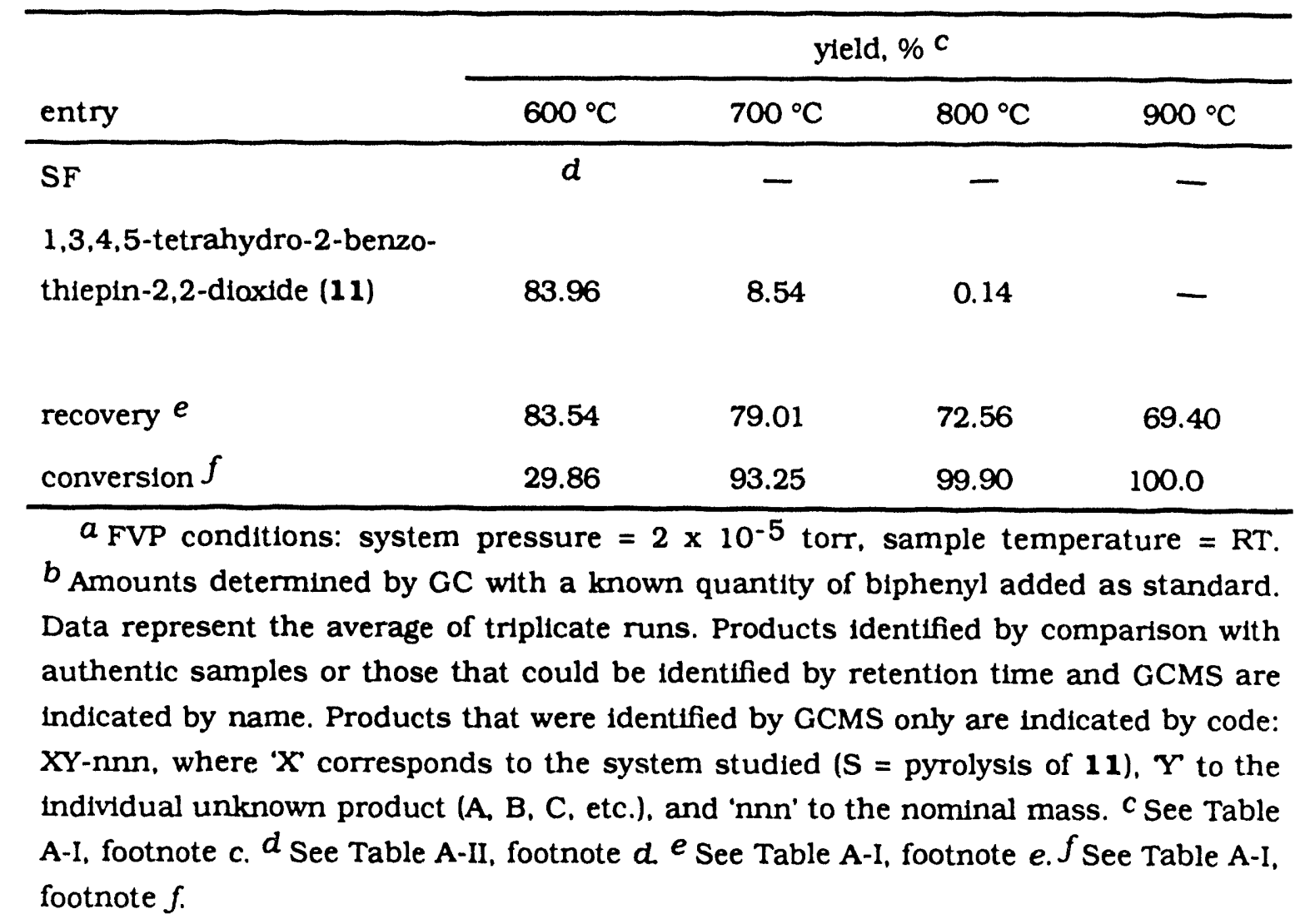




\section{APPENDIX 2 \\ SUPPLEMENTARY PROCEDURES AND CALCULATIONS}

\section{Detalled procedure for flow pyrolysis of ketone (10)}

Flow pyrolysis was performed on the same apparatus (Figure 2, Paper 1) described in the Experimental Section of Paper 1 in this dissertation except that the sample inlet was modified. An attachment was made that consisted of a Pyrex tube with 24/40 inner and outer joints attached to each end. The attachment also has a glass tube that extends below the inner joint and passes through the side wall to a ground glass stopcock. The attachment was placed on the sample inlet of the flow pyrolysis apparatus with a small amount of vacuum grease. The weighed sample (ca. $50 \mathrm{mg}$ ) in a 5-mL rcund-bottom flask was placed on the other end of the attachment with a small amount of vacuum grease.

The apparatus and sample were degassed as described in Appendix 2 of Paper 1 in this dissertation prior to pyrolysis. During the pyrolysis. Ar was flowed over the sample through the side tube on the attachment. The sample temperature was maintained for the entire pyrolysis time with a thermostatic oll bath $\left(26-27^{\circ} \mathrm{C}\right)$. A flow rate of $450 \mathrm{~mL}$ $\mathrm{min}^{-1}(\mathrm{Ar} / 1 \mathrm{~atm} /$ flow tube $=100(\mathrm{SS}))$ was maintained for $10 \mathrm{~h}$ to allow enough sample to pyrołyze for analysis (ca. 2-3 mg). Initially, ca. $50 \mathrm{mg}$ of sample was used. The sample was weighed before and after pyrolysis to determine how much had pyrolyzed. The same sample could be used for several runs. However, since the sample size effects the amount of substance pyrolyzed, the total size of the sample was not allowed to drop below ca. 35 mg. Other aspects of the flow pyrolysis were as described in Appendix 2 of Paper 1 in this dissertation. 


\section{Calculation of residence time for Dow pyrolysis of ketone (10)}

This calculation of residence time is similar to the one in Appendix 2 of Paper 1 in this dissertation. The same oven volume was used here. The pyrolysis time was determined in separate runs where the time necessary to evacuate the sample chamber from 0 to $15 \mathrm{in}$. vacuum at $450 \mathrm{~mL} \mathrm{~min}^{-1}(\mathrm{Ar} / 1 \mathrm{~atm})$ was measured.

Volume of argon at 760 torr at $300 \mathrm{~K}$ (VA1)

Pressure of sample (from Bourdon gauge)

Initial pressure of argon $=\mathrm{P}_{1}$

Final pressure of argon $=\mathrm{Pf}_{\mathrm{f}}$

Minimum pressure of system $=\mathrm{P}_{\mathrm{min}}$

Total volume of argon $=\mathrm{V}_{\mathrm{T}}$

Volume of argon $=V_{A 1}=\frac{P_{f}-P_{1}}{P_{\max }-P_{1}} V_{T}$

\section{Volume of argon at 15 torr at $1100 \mathrm{~K}\left(\mathrm{~V}_{\mathrm{A2}}\right)$}

Initial pressure of sample $=\mathrm{P}_{1}$

Final pressure of sample $=\mathrm{P}_{2}$

Initial temperature of sample $=T_{1}$

Final temperature of sample $=\mathrm{T}_{2}$

Initial volume of argon $=\mathrm{V}_{\mathrm{A} 1}$

Volume of argon $=V_{A 2}=\frac{P_{1} T_{2}}{P_{2} T_{1}} V_{A 1}$

Flow rate (Rf)

Average time $=t_{s}$

Flow rate $=R_{\mathrm{f}}=\mathrm{v}_{\mathrm{A} 2} / \mathrm{t}_{\mathrm{S}}$

\section{Residence time ( $\left.t_{r}\right)$}

Volume of oven $=V_{\text {oven }}$

Residence time $=t_{r}=V_{\text {oven }} / R_{f}$

$$
\begin{aligned}
& P_{1}=0 \text { in. vacuum } \\
& P_{f}=15 \text { in. vacuum } \\
& P_{\min }=28 \text { in. vacuum }
\end{aligned}
$$

$12 \mathrm{~L}$

$6.4 \mathrm{~L}$

760 torr

15 torr

$300 \quad \mathrm{~K}$

$1100 \quad \mathrm{~K}$

6.4 L

$1.2 \times 10^{6} \mathrm{~mL}$

$14 \min$

$8.6 \times 10^{4} \mathrm{~mL} \mathrm{~min}^{-1}$

$113 \mathrm{~mL}$

$0.08 \mathrm{~s}$ 
PAPER 3. THE HIGH-TEMPERATURE GAS-PHASE REACTIONS OF OALLYLBENZYL RADICALS GENERATED BY FLASH VACUUM PYROLYSIS OF BIS(O-ALLYLBENZYL) OXALATE 


\section{INTRODUCTION}

In the gas-phase thermal decomposition of tetralin (1), 1.2 the major products Include 1,2-dihydronaphthalene (2) and naphthalene (3), derived by the loss of hydrogen, and benzocyclobutene (4) and styrene (5), derlved by the loss of ethylene (Scheme I). Several other significant products such as indene (6), formed by the loss of the equivalent of methane from 1, are also produced. One of the mechanisms proposed ${ }^{21}$ for the formation of 2 involves the o-allylbenzyl radical (7) formed from diradical 8 by loss of a hydrogen atom. Conversion of 7 to 2 is reasonable, but previous studies 3 of

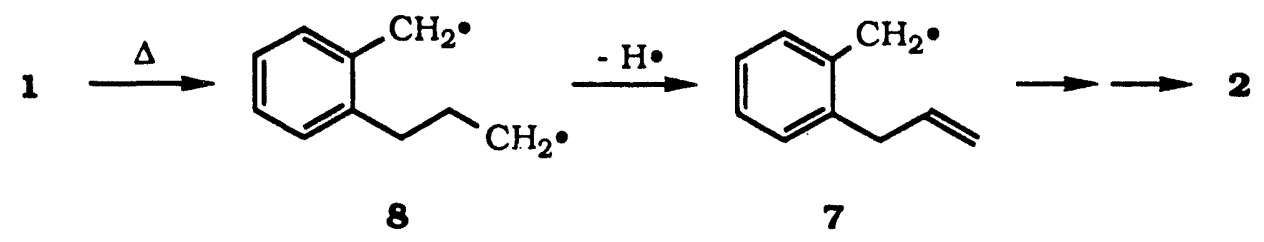

related radicals indicate that $\mathbf{7}$ could produce other products such as $\mathbf{6}$. In an attempt to determine the fate of radical 7 under high-temperature gas-phase conditions, we have studied the flash vacuum pyrolysis (FVP) of bis(o-allylbenzyl) oxalate (9). Oxalates have

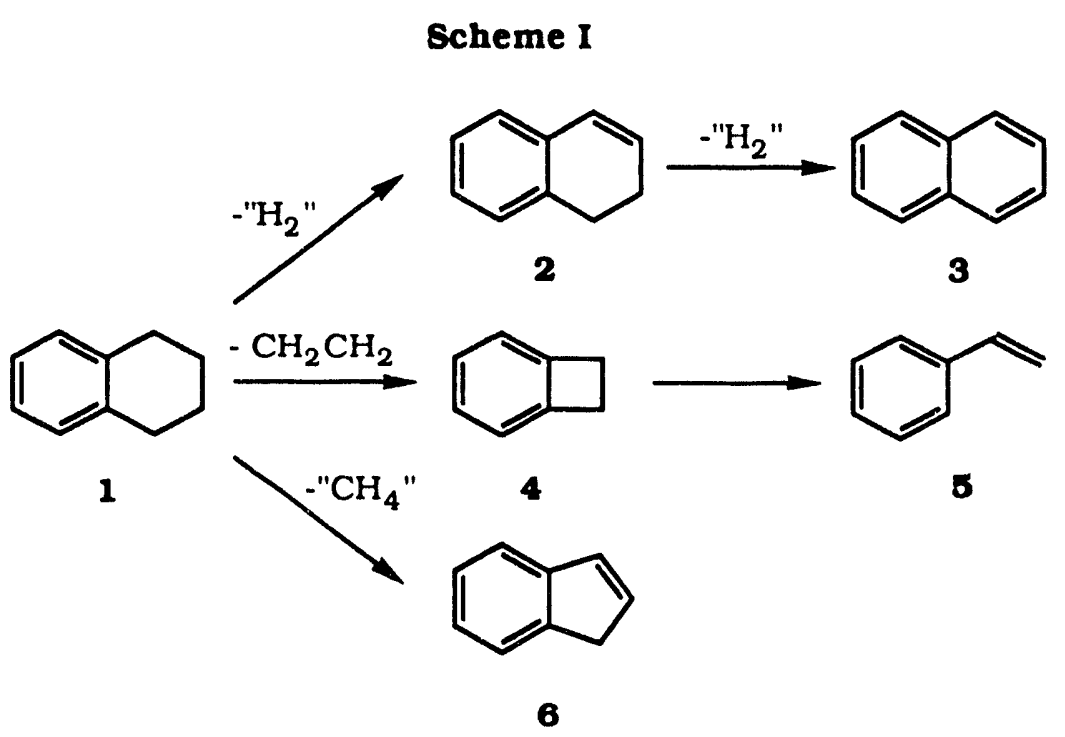


been shown to be good precursors of benzyl radicals under FVP conditions ${ }^{4}$ and we expected 9 to produce 7 in good yield. The results of the study of the FVP of 9 are<smiles>C=CCc1ccccc1COC(C)=O</smiles>

$\boldsymbol{\theta}$

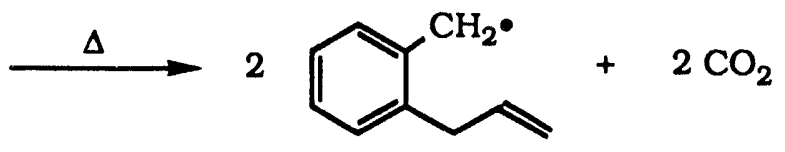

7

presented in this paper. 


\section{RESULTS}

Oxalate 9 was prepared from 1,2-dihydronaphthalene (2) by the following reaction sequence.<smiles>C1=Cc2ccccc2CC1</smiles>

2

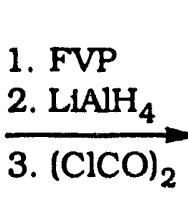<smiles>C=CCc1ccccc1COC(C)=O</smiles>

9

The FVP of 9 (Table I) leads primarlly to the formation of 1,2-dihydronaphthalene (2), naphthalene (3), indene (6), 3-methyl-1H-indene (10), and 2-methyl-1H-Indene (11). Small amounts $(<2 \%)$ of tetralin (1), benzocyclobutene (4), styrene (5), o-allyltoluene (12), and 2-methylindan (13) 5 were produced. The dimer of 7, 1,2-di(2-allylphenyl)ethane (14), was detected $(<1 \%)$ at $700-750^{\circ} \mathrm{C}$. 
Table I. Products and recovered starting material from FVP of bis(o-allylbenzyl) oxalate (9) at various oven temperatures $a, b$

\begin{tabular}{lrrrrr}
\hline & \multicolumn{5}{c}{ yield, \% } \\
\cline { 2 - 6 } entry & $700^{\circ} \mathrm{C}$ & $750^{\circ} \mathrm{C}$ & $800^{\circ} \mathrm{C}$ & $850^{\circ} \mathrm{C}$ & $900^{\circ} \mathrm{C}$ \\
\hline bis(o-allylbenzyl) oxalate (9) & 3.4 & 1.7 & 1.2 & 0.3 & - \\
1.2-dihydronaphthalene (2) & 62.6 & 62.2 & 60.5 & 55.2 & 46.4 \\
naphthalene (3) & 5.3 & 7.5 & 11.1 & 16.5 & 27.1 \\
Indene (6) & 6.3 & 6.9 & 8.2 & 10.1 & 12.3 \\
3-methyl-1H-indene (10) & 4.2 & 4.4 & 3.6 & 2.9 & 2.2 \\
2-methyl-1H-indene (11) & 1.4 & 1.5 & 1.8 & 1.7 & 1.8 \\
1.2-di(2-allylphenyl)ethane (14) & 0.7 & 0.2 & - & - & - \\
other products & $16.0 d$ & $15.5 d$ & $13.6 d$ & $13.2 d$ & $10.2 d$ \\
& & & & & \\
recovery $e$ & 71.5 & 65.1 & 68.7 & 67.1 & 59.9 \\
conversion $f$ & 96.6 & 98.3 & 98.8 & 99.7 & 100 \\
\hline
\end{tabular}

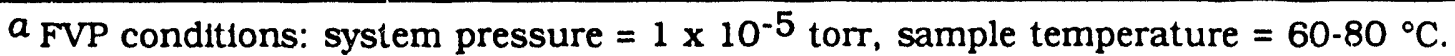
$b$ Amounts determined by GC with a known quantity of triphenylmethane added as standard. Data represent the average of triplicate runs. ${ }^{c}$ Moles of product divided by total moles of recovered material. $d$ See Table A-I in the Appendix of Paper 3, this dissertation, for a more detalled analysis. $\boldsymbol{e}^{\boldsymbol{e}}$ Total moles of recovered material divided by

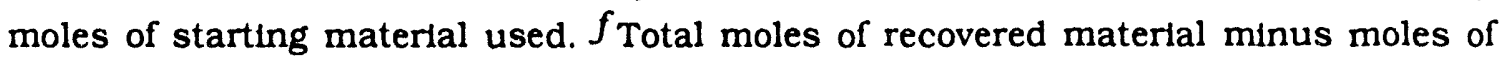
recovered starting material divided by moles of recovered material. 


\section{DISCUSSION}

The gas-phase chemistry of o-allylbenzyl radical (7) and other related radicals (Scheme II), such as 1-tetryl (1 6), 2-tetryl (16), 1-indanylmethyl (17), and 2-Indanylmethyl (18), has been studied:3 although, the high-temperature gas-phase chemistry of 7 was not investigated directly. $3 a, b$

The FVP of bis oxalate ester 9 leads primarily to the formation of 1,2-dihydronaphthalene (2) produced by loss of the $\beta$ hydrogen from 16. Significant amounts of naphthalene (3), from the secondary pyrolysis of 2 , were also observed. The thermal behavior of 7 appears to be similar to that of 5-hexenyl radicals. There may be a kinetic preference of ca. $2 \mathrm{kcal} \mathrm{mol}^{-1}$ for the formation of the five-membered 2 -indanylmethyl radical (18) over the six-membered 2-tetryl radical (16), but under pyrolysis conditions,

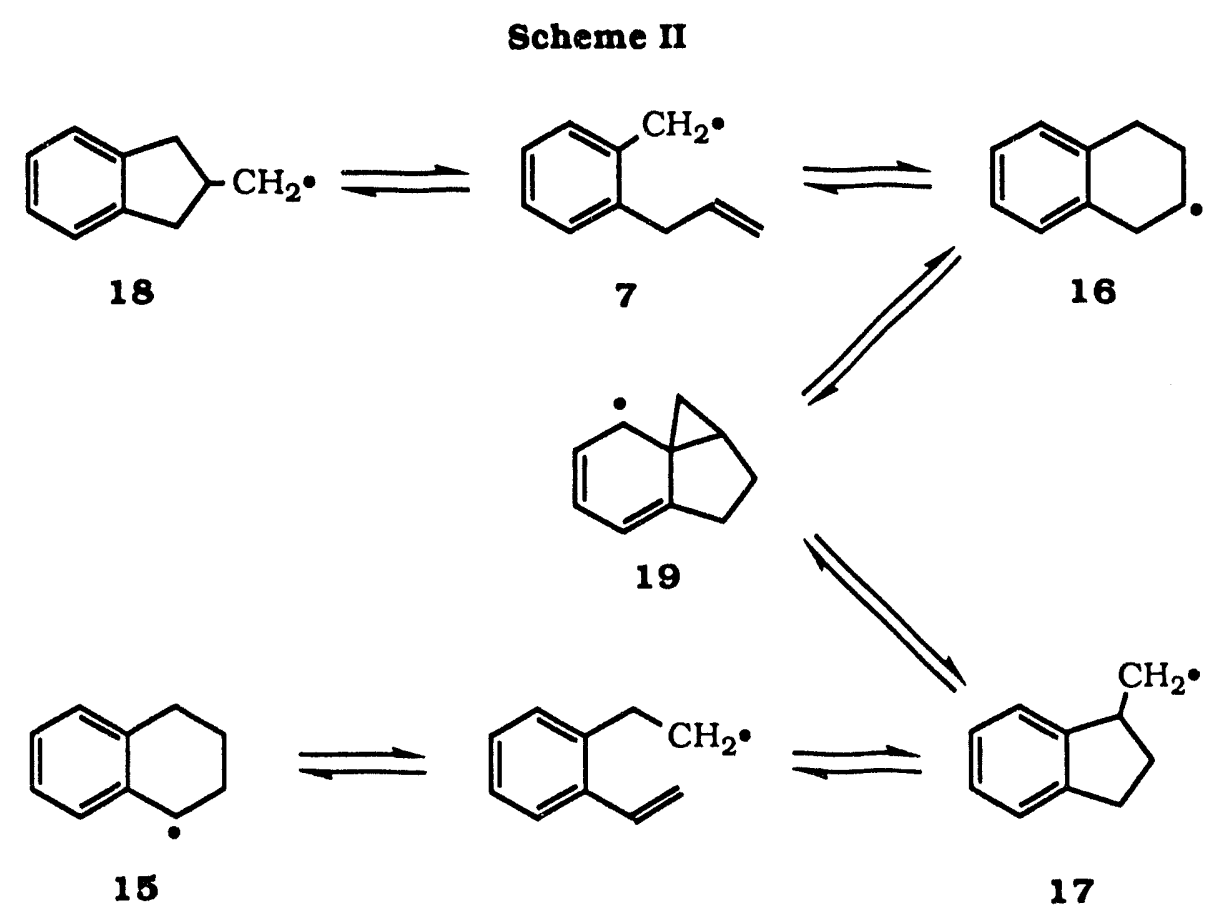


the initial closure will be reversible and the chemistry of the more stable 16 should predominate.

Consistent with the previously reported results, ${ }^{3}$ expected products such as 10 and 11, formed from radicals 17 and 18, respectively, were also observed. Indene (6), as well as small amounts of 12 and 13 were alsu formed. The ratio of 6 to dehydrogenation products 2 and 3 was low, less than 0.17 to 1 . In the pyrolysis of tetralin (1), this ratio is much higher, 0.6 to 1 at higher temperatures, and therefore the major route to 6 in the decomposition of 1 cannot involve radical 7 . Other recent work in our laboratory 7 indicates that the major source of 6 involves the pathway 1 to 12 to 13 to 6 . In the pyrolysis of axalate 9 , any of all of the radicals 17,18 , or 19 could be the source of 6 .

Another minor product at lower pyrolysis temperatures is 14 , the dimer of radical 7. Production of 14 offers further support for the formation of 7 in the pyrolysis of 9. 


\section{CONCLUSION}

The results of the FVP of bis(o-allylbenzyl) oxalate (9) are consistent with the formation of o-allylbenzyl radical (7). The major product from 7 is 1,2-dihydronaphthalene (2) which is readily explained by closure of 7 to 16 followed by the loss of a $\beta$ hydrogen atom. Other products which could come from radical 7 are formed in relatively low yields. 


\section{EXPERDMENTAI}

\section{General Procedures}

\section{Methods and materials}

Some general methods have been described previously. $81_{\mathrm{H}}$ NMR spectra were recorded on a Nicolet NT-300 spectrometer. FTIR spectra were obtained on an IBM IR/98 spectrophotometer. GCMS were performed on a Finnegan 4000 mass spectrometer. HRMS were performed on a Kratos MS-50 mass spectrometer. All materials were commerctally avallable and used as recetved, except where indicated.

Big(o-allylbenzyl) oxalate (9) o-(3-Hydroxypropyl)benzyl alcohol $(3.0 \mathrm{~g}$. $0.018 \mathrm{~mol})$, prepared as described previously, ${ }^{9}$ was dissolved in dry ether $(50 \mathrm{~mL})$ and triethylamine $\left(4.0 \mathrm{~g}, 0.040 \mathrm{~mol}, \mathrm{ca} .5 .5 \mathrm{~mL}\right.$ ) was added. The mixture was cooled to $0^{\circ} \mathrm{C}$ and a solution of acetyl chloride $(3.1 \mathrm{~g} .0 .040 \mathrm{~mol}, \mathrm{ca} .2 .8 \mathrm{~mL})$ in ether $(20 \mathrm{~mL})$ was added dropwise. After the addition was complete, the reaction mixture was stirred for $10 \mathrm{~min}$ at $0{ }^{\circ} \mathrm{C}$ and then overnight at room temperature. The reaction mixture was washed with $\mathrm{H}_{2} \mathrm{O}(20 \mathrm{~mL})$, saturated $\mathrm{NaHCO}_{3}(20 \mathrm{~mL})$ and $\mathrm{H}_{2} \mathrm{O}(20 \mathrm{~mL})$ and then dried $\left(\mathrm{MgSO}_{4}\right)$. The solvent was removed in vacuo to yleld o-(3-acetoxypropyl)benzyl acetate $(4.1 \mathrm{~g}, 0.016 \mathrm{~mol}$, $89 \%$ yield). FTIR (thin film) $2960,1749,1454,1383,1367,1259,1034,758 ;{ }^{1}$ H NMR $\left(\mathrm{CDCl}_{3}\right) \delta 7.37-7.18(\mathrm{~m}, 4 \mathrm{H}), 5.14(\mathrm{~s}, 2 \mathrm{H}), 4.11(\mathrm{t}, J=6.4 \mathrm{~Hz}, 2 \mathrm{H}), 2.74$ (t, $J=7.8 \mathrm{~Hz}, 2$ H), $2.11(\mathrm{~s}, 3 \mathrm{H}), 2.07$ (s, $3 \mathrm{H}), 2.01-1.90(\mathrm{~m}, 2 \mathrm{H})$.

o-(3-Acetoxypropyl)benzyl acetate $(3.9 \mathrm{~g}, 0.016 \mathrm{~mol})$ was pyrolyzed at $700{ }^{\circ} \mathrm{C}$ and 1

$x 10^{-5}$ torr with a sample temperature of $80^{\circ} \mathrm{C}$. 10 The pyrolysate was dissolved in ether and treated with $\mathrm{K}_{2} \mathrm{CO}_{3}$. The solvent was removed in vacuo and the crude product was purified by flash chromatography on a sillica gel column $(50 \times 150 \mathrm{~mm})$ with $1: 1$ hexanes 
to $\mathrm{CH}_{2} \mathrm{Cl}_{2}$ to yield o-allylbenzyl acetate $(1.5 \mathrm{~g}, 7.9 \mathrm{mmol}, 49 \%$ yield). FTIR (thin film) 2924, 1742, 1229, 1026, 754; ${ }^{1} \mathrm{H} \mathrm{NMR}_{\left(\mathrm{CDCl}_{3}\right)} \delta 7.37-7.18(\mathrm{~m}, 4 \mathrm{H}), 5.96\left(\mathrm{ddt}, J_{\mathrm{d}}=16.8\right.$ $\mathrm{Hz}, J_{\mathrm{d}}=10.3 \mathrm{~Hz}, \mathcal{I}_{\mathrm{t}}=6.3 \mathrm{~Hz}, 1 \mathrm{H}$ ), 5.07 (dd, $J_{\mathrm{d}}=10.2 \mathrm{~Hz}, J_{\mathrm{d}}=1.1 \mathrm{~Hz}, 1 \mathrm{H}$ ), 4.99 (dd, $J_{\mathrm{d}}$ $\left.=17.1 \mathrm{~Hz}, J_{\mathrm{d}}=1.1 \mathrm{~Hz}, 1 \mathrm{H}\right), 5.13(\mathrm{~s}, 2 \mathrm{H}), 3.44$ (d, $\left.J=6.2 \mathrm{~Hz}, 2 \mathrm{H}\right), 2.09$ (s, $3 \mathrm{H}$ ).

o-Allylbenzyl acetate (1.5 g. $7.9 \mathrm{mmol})$ was dissolved in THF (10 mL) and added dropwise to a slurry of $\mathrm{LAAlH}_{4}(0.4 \mathrm{~g}, 0.010 \mathrm{~mol})$ in THF $(50 \mathrm{~mL})$ at $0{ }^{\circ} \mathrm{C}$. The reaction mixture was allowed to warm to room temperature and stirred for $2 \mathrm{~h}$. A slurry of wet $\mathrm{Na}_{2} \mathrm{SO}_{4}$ was added to the reaction mixture until evolution of $\mathrm{H}_{2}$ ceased. The white solid was filtered off and washed with ethyl acetate. The filtrate was dried (MgSO4) and the solvent was removed in vacuo to yield o-allylbenzyl alcohol (1.1 g. $7.4 \mathrm{mmol}, 94 \%$ yield). FTIR (thin film) 3333 (br), 2918, 1040; $\left.{ }^{1} \mathrm{H} \mathrm{NMR} \mathrm{(CDCl} 3\right) \delta 7.41-7.36$ (m, $\left.1 \mathrm{H}\right), 7.34-7.18$ $(\mathrm{m}, 3 \mathrm{H}), 6.01$ (ddt, $\left.J_{\mathrm{d}}=16.8 \mathrm{~Hz}, J_{\mathrm{d}}=10.4 \mathrm{~Hz}, J_{\mathrm{t}}=6.3 \mathrm{~Hz}, 1 \mathrm{H}\right), 5.07\left(\mathrm{dq}, J_{\mathrm{d}}=10.1 \mathrm{~Hz}\right.$, $\left.J_{\mathrm{q}}=1.5 \mathrm{~Hz}, 1 \mathrm{H}\right), 5.00\left(\mathrm{dd}, J_{\mathrm{d}}=17.2 \mathrm{~Hz}, J_{\mathrm{d}}=1.5 \mathrm{~Hz}, 1 \mathrm{H}\right), 4.71(\mathrm{~d}, J=5.9 \mathrm{~Hz}, 2 \mathrm{H}), 3.48$ (dt, $\left.J_{\mathrm{d}}=6.2 \mathrm{~Hz}, J_{\mathrm{t}}=1.4 \mathrm{~Hz}, 2 \mathrm{H}\right), 1.26(\mathrm{t}, J=6.0 \mathrm{~Hz}, 1 \mathrm{H})\left[\mathrm{dit} .6 \mathrm{c} 1_{\mathrm{H} \mathrm{NMR}}\left(\mathrm{CDCl}_{3}\right) \delta 7.6-\right.$ $7.1(\mathrm{~m}, 4 \mathrm{H}), 6.02$ (ddt, $\left.J_{\mathrm{d}}=16.6 \mathrm{~Hz}, J_{\mathrm{d}}=10.5 \mathrm{~Hz}, J_{\mathrm{t}}=6.1 \mathrm{~Hz}, 1 \mathrm{H}\right), 5.05(\mathrm{~m}, 1 \mathrm{H}(\mathrm{cis})$ ). $5.0(\mathrm{~m}, 1 \mathrm{H}($ trans)), $4.70(\mathrm{~s}, 2 \mathrm{H}), 3.47(\mathrm{dt}, 2 \mathrm{H}), 1.6(\mathrm{~s}, 1 \mathrm{H})]$.

o-Allylbenzyl alcohol (1.2 g. $8.0 \mathrm{mmol})$ was dissolved in ether (150 mL) and triethylamine $(1.1 \mathrm{~g} .0 .011 \mathrm{~mol})$ was added. The reaction mixture was cooled to $0{ }^{\circ} \mathrm{C}$ and oxalyl chloride $(0.8 \mathrm{~g}, 6.0 \mathrm{mmol})$ in ether $(10 \mathrm{~mL})$ was added dropwise. After the reaction mixture was stirred for $1 \mathrm{~h}$ at room temperature, it was extracted with $\mathrm{H}_{2} \mathrm{O}(50 \mathrm{~mL})$, saturated $\mathrm{NaHCO}_{3}(2 \times 50 \mathrm{~mL}), \mathrm{H}_{2} \mathrm{O}(50 \mathrm{~mL})$, and saturated $\mathrm{NaCl}(50 \mathrm{~mL})$ and then dried $\left(\mathrm{MgSO}_{4}\right)$. The solvent was removed in vacuo and the crude product was purified by flash chromatography on a silica gel column $(30 \times 150 \mathrm{~mm})$ with $1: 1 \mathrm{CH}_{2} \mathrm{Cl}_{2}$ to hexanes to yield bis(o-allylbenzyl) oxalate (1.1 g. $3.2 \mathrm{mmol}, 80 \%$ yield). FTIR (thin film) 2957, 2924. $1767,1744,1155 ;{ }^{1} \mathrm{H}$ NMR $\left(\mathrm{CDCl}_{3}\right) \delta 7.41-7.19(\mathrm{~m}, 4 \mathrm{H}), 5.94$ (ddt, $J_{\mathrm{d}}=16.8 \mathrm{~Hz}, J_{\mathrm{d}}=$ 
$\left.10.4 \mathrm{~Hz}, J_{\mathrm{t}}=6.3 \mathrm{~Hz}, 1 \mathrm{H}\right), 5.33(\mathrm{~s}, 2 \mathrm{H}), 5.02\left(\mathrm{dq}, J_{\mathrm{d}}=10.1 \mathrm{~Hz}, J_{\mathrm{q}}=1.5 \mathrm{~Hz}, 1 \mathrm{H}\right), 4.95$ (dd, $\left.J_{\mathrm{d}}=17.0 \mathrm{~Hz}, J_{\mathrm{d}}=1.7 \mathrm{~Hz}, 1 \mathrm{H}\right), 3.45\left(\mathrm{dt}, J_{\mathrm{d}}=6.2 \mathrm{~Hz}, J_{\mathrm{t}}=1.4 \mathrm{~Hz}, 2 \mathrm{H}\right.$ ); GCMS (CI, $\left.\mathrm{NH}_{3}\right) \mathrm{m} / e 368\left(\mathrm{M}+\mathrm{NH}_{4}\right)$; GCMS (EI, $70 \mathrm{eV}$ ) m/e (\% base peak) 260 (5.5), 219 (4.8), 131 (100), 130 (98.6), 116 (15.6), 115 (22.0), 91 (45.6): Analysis calculated for $\mathrm{C}_{22} \mathrm{H}_{22} \mathrm{O}_{4}, \mathrm{C}$ 75.41\%, H 6.33\%; measured, C 75.42\%, H 6.36\%.

Flash vacuum pyrolysis Flash vacuum pyrolysis (FVP) was performed as previously described. $3 c, 9$

Product analysis FVP reaction mixtures were analyzed by capillary gas chromatography on a Hewlett-Packard HP5840A gas chromatograph equipped with a 30-m (0.25- $\mu \mathrm{m}$ film thickness) DB-1701 capillary column using the analytical procedure previously described except that the standard used was triphenylmethane instead of biphenyl. $7 a$ 


\section{REFERENCES}

(1) Poutsma, M. L. A Review of Thermolysis Studies of Model Compounds Relevant to Processing of Coali ORNL/TM-10673, Oak Ridge National Laboratory, Oak Ridge, TN 37831. This review is avallablc from National Technical Information Service, $U$. S. Dept. of Commerce, 5285 Port Royal Rd., Springfield, VA 22161.

(2) (a) Badger, G. M.: Kimber, R. W. L. J. Chem. Soc. 1960, 266. (b) Badger, G. M.; Kimber, R. W. L.; Novotny, J. Aust. J. Chem. 1962, 15, 616. (c) Loudon, A. G.: Maccoll, A.; Wong, S. K. J. Chem. Soc. B 1970, 1733. (d) Penninger, J. M. L.; Slotboom, H. W. Recl. Trav. Chim. Pays-bays 1973, 92, 513. (e) Penninger, J. M. L.; Slotboom, H. W. Ibid. 1973, 92, 1089. (f) Tominaga, H.; Yahagi, U. J. Fac. Eng., Univ. Tokyo, Ser. A 1977, 15, 68. (g) Bredael, P.; Vinh. T. H. Fuel 1979, 58, 211. (h) Gangwer, T.; MacKenzie, D.: Casano, S. J. Phys. Chem. 1979, 83, 2013. (1) Berman, M. R.: Comita, P. B.: Moore, C. B.; Bergman, R. G. J. Amer. Chem. Soc. 1980, 102, 5692. () Cyprès, R.; Bredael, P. Fuel Process. Tech. 1980, 3, 297. (k) Trushkova, L. V.: Magaril, R. Z.; Korzun, N. V.: Bulatov, R. A. Russ. J. Phys. Chem. 1980, 54, 1062. (1) Comita, P. B.; Berman, M. R.; Moore, B. C.; Bergman, R. G. J. Phys. Chem. 1981, 85, 3266. (m) Takahashi, K.; Ogino, Y. Fuel 1981, 60, 975. (n) Trahanovsky, W. S.: Swenson, K. E. J. Org. Chem. 1981, 46, 2984. (0) Bajus, M.; Baxa, J. Coll. Czech. Chem. Commun. 1982, 47, 1838. (p) Penninger, J. M. L. Int. J. Chem. Kinetics 1982, 14, 761. (q) Hillebrand, W.; Hodek, W.; Kolling. G. Fuel 1984, 63, 756. (r) Korzun, N. V.: Trushkova, L. V. Kinetics Catal. 1985, 26, 195. (s) Tsang. W.; Cul, J. P. J. Amer. Chem. Soc. 1990, 112, 1665.

(3) (a) Franz, J. A.: Camaioni, D. M. Fuel 1980, 59, 803. (b) Franz, J. A.; Camaioni, D. M. J. Org. Chem. 1980, 45, 5247. (c) Franz, J. A.; Barrows, R. D.; Camalond, D. M. J. Am. Chem. Soc. 1984, 106, 3964. (d) Franz, J. A.; Suleman, N. K.; Alnajjar, M. S. J. Org. Chem. 1986, 51, 19. (e) Franz, J. A.; Alnajjar, M. S.; Barrows, R. D.; Camaionl, D. M.; Suleman, N. K. J. Org. Chem. 1986, 51, 1446.

(4) (a) Trahanovsky, W. S.; Ong, C. C.: Lawson, J. A. J. Amer. Chem. Soc. 1968. 90. 2839. (b) Trahanovsky, W. S.; Ong, C. C. J. Amer. Chem. Soc. 1970, 92, 7174. (c) Trahanovsky, W. S.; Ong, C. C.; Pataky, J. G.; Weitl, F. L.; Mullen, P. W.; Clardy, J. C.; Hansen, R. S. J. Org. Chem. 1971, 36, 3575.

(5) In the liquid-phase pyrolysis of 1, the major ring-contracted product has been identified as 1 -methylindan, 6 but we have conclusively identified the major methylindan in gas-phase pyrolysis of 1 as the 2-methyl isomer (7). Some workers have incorrectly reported 1 -methylindan as the gas-phase pyrolysis product. 2 d, e,p 
(6) Benjamin, B. M.; Hagaman, E. W.: Raaen, V. F.; Collins, C. J. Fuel 1979, 58, 386.

(7) (a) Malandra, J. L.; Zhu, J.; Lee, S.-K.; Spurlin. S. R.; Tunkel, J. L.; Fischer, D. R.; Yeung. E. S.; Trahanovsky. W. S., manuscript in preparation. (Paper 1, this dissertation] (b) Trahanovsky, W. S.: Malandra, J. L.: Ferguson, J. M. J. Amer. Chem. Soc. 1993, 115, 0000. [Paper 5, this dissertation]

(8) (a) Trahanovsky, W. S.: Cassady, T. J.; Woods, T. L. J. Amer. Chem. Soc. 1981. 103, 6691. (b) Chou, C.-H.: Trahanovsky, W. S. J. Amer. Chem. Soc. 1986, 108. 4138.

(9) Malandra, J. L.; Trahanovsky, W. S., manuscript in preparation. [Paper 2, this dissertiation]

(10) Commercial apparatus is avallable from Kontes Scientific Glassware, Vineland, NJ 08360. For review, see Brown. R. C. F. Pyrolysis Methods in Organic Chemistry. Academic: New York, 1980. Chapter 2. 
APPENDIX

\section{SUPPLEMENTARY DATA TABLE}

Table A-I. Products and recovered starting material, total recovery of material, and conversion from the FVP of bis(o-allylbenzyl) oxalate (9) at various oven temperatures $a, b$

\begin{tabular}{|c|c|c|c|c|c|}
\hline \multirow[b]{2}{*}{ entry } & \multicolumn{5}{|c|}{ yield, \% c } \\
\hline & $700^{\circ} \mathrm{C}$ & $750^{\circ} \mathrm{C}$ & $800^{\circ} \mathrm{C}$ & $850^{\circ} \mathrm{C}$ & $900^{\circ} \mathrm{C}$ \\
\hline toluene & 0.84 & 0.81 & 0.66 & 1.78 & 0.95 \\
\hline ethylbenzene & 0.64 & 0.52 & 0.55 & 0.82 & 0.82 \\
\hline o-xylene & 0.41 & 0.64 & 0.58 & 0.90 & 0.79 \\
\hline styrene (5) & 0.44 & 0.40 & 0.43 & 0.61 & 0.68 \\
\hline benzocyclobutene (4) & 0.21 & 0.26 & 0.29 & 0.37 & 0.40 \\
\hline allylbenzene & 0.23 & 0.19 & 0.19 & 0.20 & 0.15 \\
\hline o-ethyltoluene & 0.27 & 0.36 & 0.45 & 0.50 & 0.42 \\
\hline o-methylstyrene & 0.57 & 0.68 & 0.68 & 0.84 & 0.81 \\
\hline o-allyltoluene (12) & 1.42 & 1.03 & 0.84 & 0.65 & 0.32 \\
\hline indene (6) & 6.29 & 6.89 & 8.15 & 10.06 & 12.32 \\
\hline 2-methylindan (13) & 0.22 & 0.24 & 0.32 & 0.36 & 0.35 \\
\hline TD- $130\left[\mathrm{C}_{10} \mathrm{H}_{10} \mathrm{O}\right.$ & 0.96 & 1.02 & 0.88 & 0.75 & 0.62 \\
\hline TE-130 $\left[\mathrm{C}_{10} \mathrm{H}_{10} \mathrm{O}\right.$ & - & 0.08 & - & 0.17 & 0.22 \\
\hline$T F-130\left[\mathrm{C}_{10} \mathrm{H}_{10}\right]$ & 一 & - & - & 0.21 & 0.26 \\
\hline o-methylbenzaldehyde & 0.17 & 0.20 & - & - & - \\
\hline o-(1-propenyl)toluene & 0.20 & 0.18 & - & 0.16 & 0.14 \\
\hline
\end{tabular}

Table A-I continues on next page 
Table A-I. Continued

\begin{tabular}{|c|c|c|c|c|c|}
\hline \multirow[b]{2}{*}{ entry } & \multicolumn{5}{|c|}{ yield, \% c } \\
\hline & $700^{\circ} \mathrm{C}$ & $750^{\circ} \mathrm{C}$ & $800^{\circ} \mathrm{C}$ & $850^{\circ} \mathrm{C}$ & $900^{\circ} \mathrm{C}$ \\
\hline $\mathrm{TH}-130\left[\mathrm{C}_{10} \mathrm{H}_{10} \mathrm{l}\right.$ & 0.48 & 0.78 & 0.83 & 0.84 & 0.84 \\
\hline 3-methyl-1 $H$-indene (10) & 4.19 & 4.35 & 3.57 & 2.88 & 2.18 \\
\hline tetralin (1) & 0.97 & 1.15 & 1.11 & 1.16 & 1.01 \\
\hline 2-methyl-1H-indene (11) & 1.45 & 1.52 & 1.79 & 1.70 & 1.81 \\
\hline 1.2-dihydronaphthalene (2) & 62.63 & 62.20 & 60.54 & 55.23 & 46.44 \\
\hline $\mathrm{TL}-128\left[\mathrm{C}_{10} \mathrm{H}_{8}\right]$ & - & - & - & 0.11 & 0.22 \\
\hline 1.4-dihydronaphthalene & 1.59 & 1.02 & 0.35 & 0.22 & - \\
\hline $\mathrm{OA}-144\left[\mathrm{C}_{11} \mathrm{H}_{12}\right]$ & - & 0.08 & - & - & - \\
\hline naphthalene (3) & 5.30 & 7.54 & 11.12 & 16.54 & 27.11 \\
\hline 1-methyltetralin & 0.62 & 0.69 & 0.86 & 0.74 & 0.63 \\
\hline siloxane $\left(\left(\mathrm{CH}_{3}\right)_{2} \mathrm{StO}_{6}\right.$ & $d$ & $d$ & - & - & - \\
\hline $\mathrm{OB}-144\left[\mathrm{C}_{11} \mathrm{H}_{12}\right]$ & 0.10 & 0.15 & 0.33 & - & - \\
\hline TO- $148\left[\mathrm{C}_{11} \mathrm{H}_{16}\right]$ & 1.65 & 1.98 & 2.10 & 1.09 & 0.52 \\
\hline OC- $146\left[\mathrm{C}_{11} \mathrm{H}_{14}\right.$ or $\left.\mathrm{C}_{10} \mathrm{H}_{10} \mathrm{O}\right]$ & 0.67 & 0.35 & 0.31 & 0.11 & - \\
\hline OD- $146\left[\mathrm{C}_{11} \mathrm{H}_{14}\right.$ or $\left.\mathrm{C}_{10} \mathrm{H}_{10} \mathrm{O}\right]$ & 0.56 & 0.40 & 0.26 & - & - \\
\hline $\mathrm{OE}-146\left[\mathrm{C}_{11} \mathrm{H}_{14}\right.$ or $\left.\mathrm{C}_{10} \mathrm{H}_{10} \mathrm{O}\right]$ & 1.26 & 0.56 & 0.73 & 0.13 & - \\
\hline $\mathrm{OF}-22 \mathrm{O}\left[\mathrm{C}_{12} \mathrm{H}_{12} \mathrm{O}_{4}\right]$ & 0.13 & 0.09 & 0.16 & 0.13 & - \\
\hline OG & $d$ & $d$ & $d$ & - & - \\
\hline bis(o-allylbenzyl) oxalate (9) & 3.44 & 1.72 & 1.22 & 0.33 & - \\
\hline $\mathrm{OH}-148\left[\mathrm{C}_{11} \mathrm{H}_{16}\right.$ or $\left.\mathrm{C}_{10} \mathrm{H}_{12} \mathrm{O}\right]$ & 0.33 & 1.45 & 0.45 & - & - \\
\hline 1-tetralone & 0.32 & 0.24 & 0.23 & 0.39 & - \\
\hline OI & - & - & $d$ & - & - \\
\hline
\end{tabular}

Table A-I continues on next page 
Table A-I. Continued

\begin{tabular}{lccccc}
\hline & \multicolumn{5}{c}{ yleld, \% } \\
\cline { 2 - 5 } entry & $700{ }^{\circ} \mathrm{C}$ & $750{ }^{\circ} \mathrm{C}$ & $800{ }^{\circ} \mathrm{C}$ & $850{ }^{\circ} \mathrm{C}$ & $900{ }^{\circ} \mathrm{C}$ \\
\hline 1.2-diphenylethane & 0.49 & - & - & - & - \\
1,2 -di(2-methylphenyl)ethane & 0.25 & - & - & - & - \\
OJ & - & - & - & - & $d$ \\
OK & - & - & $d$ & - & $d$ \\
OL & - & - & - & - & $d$ \\
OM & - & - & - & - & $d$ \\
1,2 -dil(2-allylphenyl)ethane (14) & 0.69 & 0.24 & - & - & - \\
& & & & & \\
recovery $e$ & 71.49 & 65.07 & 68.72 & 67.12 & 59.93 \\
conversion $f$ & 96.56 & 98.28 & 98.78 & 99.67 & 100.0 \\
\hline
\end{tabular}

$a_{\text {FVP }}$ conditions: system pressure $=1 \times 10^{-5}$ torr, sample temperature $=60-80^{\circ} \mathrm{C}$.

$b$ Amounts determined by GC with a known quantity of triphenylmethane added as standard. Data represent the average of triplicate runs. Products identified by comparison with authentic samples or those that could be identified by retention time and GCMS are indicated by name. Products that were identified by GCMS only are indicated by code: $X Y-n n n$, where ' $X$ ' corresponds to the system studied $(O=$ pyrolysis of $9, T=$ pyrolysis of 1 ). $~ Y$ ' to the individual unknown product ( $A, B, C$, etc.), and ' $n$ nn' to the nominal mass. ${ }^{c}$ Moles of product divided by total moles of recovered material. $d$ Product which constitutes $\leq 0.50 \%$ total area by GC. $e^{e}$ Total moles of recovered material divided by moles of starting material used. $f$ Total moles of recovered material minus moles of recovered starting material divided by total moles of recovered material. 
PAPER 4. THE FLASH VACUUM PYROLYSIS OF 1,4-DIPHENYLBUTANE 


\section{INTRODUCTION}

We have concluded from our study of the gas-phase decomposition of tetralin (1) that the lowest energy unimolecular reaction of 1 is ethylene loss to form benzocyclobutene (2), ${ }^{1}$ a conclusion that has also been reached from a study of the laser-induced decomposition of 1.2 One of the mechanisms proposed $2 b$ for the thermal decomposition of 1 to 2 involves cleavage of the weak benzylic carbon-carbon bond to form diradical 3 followed by loss of ethylene from 3 to form o-xylylene (4) which is kncwn to

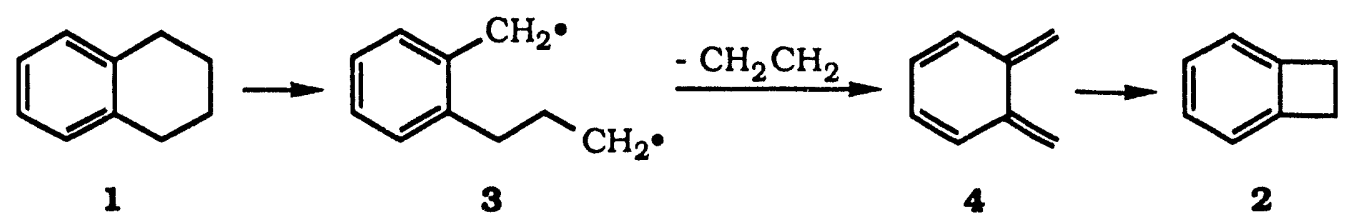

close to 2 at high temperatures. ${ }^{3}$ From our study of the pyrolysis of ketone $\mathbf{5}$ and sulfone $6,{ }^{4}$ we have concluded that diradical 3 is produced by both of these compounds. The results show, however, that the major reactions of 3 are coupling to form 1 and disproportionation to form o-allyltoluene (7). Little or no cleavage of the $\beta$ carbon-car-

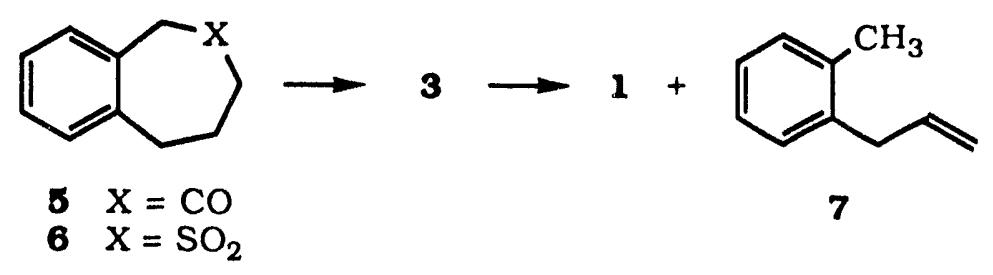

bon bond of diradical 3 to form 4 and subsequently 2 is observed.

Cleavage of the $\beta$ carbon-carbon bond in alkyl radicals is common, 5 but this does not seem to be a favorable reaction for diradical 3. It is conceivable that under high-temperature gas-phase pyrolysis conditions that a 3-arylpropyl radical losses a $\beta$ hydrogen atom or undergoes cyclization in preference to cleavage of the $\beta$ carbon-carbon bond. In order to determine the fate of a simple arylpropyl radical under these 
conditions, we have studied the products of the 3-phenylpropyl radical (8) produced by

$\mathrm{PhCH}_{2} \mathrm{CH}_{2} \mathrm{CH}_{2} \mathrm{CH}_{2} \mathrm{Ph} \longrightarrow \mathrm{PhCH}_{2} \mathrm{CH}_{2} \mathrm{CH}_{2} \bullet+\cdot \mathrm{CH}_{2} \mathrm{Ph}$

the pyrolysis of 1,4-diphenylbutane (9). The results of this study are reported in this paper. 


\section{RESULTS}

FVP of 9 at $10^{-5}$ torr $\left(700-900^{\circ} \mathrm{C}\right)$ produces 1.2 -diphenylethane $(10)$ as the major product (Table I). At higher temperatures $\left(850-900^{\circ} \mathrm{C}\right)$, ca. $10 \%$ toluene $(11)$ is formed. Small amounts $(<2.5 \%)$ of indan (12), styrene (13), ethylbenzene (14), allylbenzene (15), butylbenzene (19), and diphenylmethane (20) are also produced. 
Table I. Products and recovered starting material from the FVP of 1,4-diphenylbutane (9) at various oven temperatures $a, b$

\begin{tabular}{|c|c|c|c|c|c|}
\hline \multirow[b]{2}{*}{ entry } & \multicolumn{5}{|c|}{ yleld. $\% c$} \\
\hline & $700^{\circ} \mathrm{C}$ & $750^{\circ} \mathrm{C}$ & $800^{\circ} \mathrm{C}$ & $850^{\circ} \mathrm{C}$ & $900^{\circ} \mathrm{C}$ \\
\hline 1,4-diphenylbutane (9) & 98.2 & 91.1 & 65.7 & 23.4 & 7.1 \\
\hline 1,2-diphenylethane (10) & 1.6 & 7.8 & 30.4 & 62.9 & 71.9 \\
\hline toluene (11) & - & 0.1 & 0.8 & 6.4 & 11.2 \\
\hline indan (12) & - & 0.1 & 0.8 & 1.9 & 2.2 \\
\hline styrene (13) & - & 0.1 & 0.6 & 1.9 & 2.3 \\
\hline ethylbenzene (14) & - & - & 0.1 & 0.7 & 1.5 \\
\hline allylbenzene (15) & - & - & 0.2 & 0.4 & 0.4 \\
\hline butylbenzene (19) & 0.1 & 0.2 & 0.4 & 0.4 & 0.5 \\
\hline diphenylmethane (20) & - & - & $<0.1$ & 0.3 & 0.8 \\
\hline other products & - & $0.6^{d}$ & $1.1 d$ & $1.7^{d}$ & $2.2^{d}$ \\
\hline recovery $e$ & 98.9 & 98.6 & 96.4 & 94.0 & 85.5 \\
\hline conversion $f$ & 1.8 & 8.9 & 34.3 & 76.6 & 92.9 \\
\hline
\end{tabular}

$a_{\text {FVP }}$ conditions: system pressure $=2 \times 10^{-5}$ torr, sample temperature $=\mathrm{RT}$. ${ }^{b}$ Amounts determined by GC with a known quantity of triphenylmethane added as standard. Data represent the average of triplicate runs. ${ }^{c}$ Moles of product divided by total moles of recovered material. $d$ See Table A-1 in the Appendix of Paper 3, this dissertation, for a more detalled analysis. ${ }^{e}$ Total moles of recovered material divided

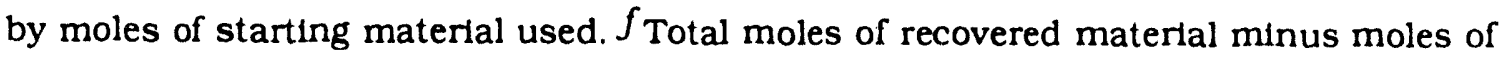
recovered starting material divided by total moles of recovered material. 


\section{DIscussion}

The major product from the FVP of $9,1,2$-diphenylethane (10), is consistent with the expected mechanism: cleavage of the benzylic carbon-carbon bond to form a benzyl radical and 8 (eq 1) followed by the loss of ethylene from 8 to form another benzyl

$$
8 \longrightarrow \mathrm{CH}_{2}=\mathrm{CH}_{2}+\cdot \mathrm{CH}_{2} \mathrm{Ph}
$$

radical (eq 2). Benzyl radicals produced under these conditions couple to $\mathrm{m} 10$ (eq 3). 6

$$
2 \mathrm{PhCH}_{2} \bullet \longrightarrow \mathrm{PhCH}_{2} \mathrm{CH}_{2} \mathrm{Ph}
$$

$$
10
$$

The production of indan (12) supports the formation of 8 (eq 4) and the low yield of 12<smiles>[CH]C1Cc2ccccc2C1</smiles>

12

shows that under these conditions cleavage of the $\beta$ carbon-carbon bond of 8 is favored over cyclization. Loss of a $\beta$ hydrogen atom from 8 could account for the production of allylbenzene (15) (eq 5) but 15 could also arise from radical induced decomposition of 9

$$
8 \longrightarrow \underset{15}{\mathrm{PhCH}_{2} \mathrm{CH}}=\mathrm{CH}_{2}+\mathrm{H} \bullet
$$

as discussed below. The low yield of 15, whatever its source, means that cleavage of the $\beta$ carbon-carbon bond is much more important than $\beta$ carbon-hydrogen bond cleavage.

In liquid-phase studies of the decomposition of 9.5 .7 radical chain reactions account for the decomposition products. The reaction of a benzyl radical with 9 leads to the formation of radical 16 or 17 (eq 6,7). Radical 16 decomposes to the 2-phenylethyl

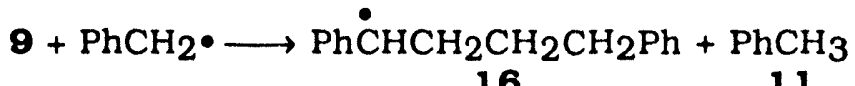

$$
\begin{aligned}
& 1611 \\
& \text { 9 }+\mathrm{PhCH}_{2} \bullet \longrightarrow \mathrm{PhCH}_{2} \stackrel{\bullet}{\mathrm{C}} \mathrm{HCH}_{2} \mathrm{CH}_{2} \mathrm{Ph}+11 \\
& 17
\end{aligned}
$$


radical (18) and styrene (13) (eq 8) and radical 17 fragments to benzyl radical and

$$
\begin{aligned}
& 16 \longrightarrow \mathrm{PhCH}=\mathrm{CH}_{2}+\cdot \mathrm{CH}_{2} \mathrm{CH}_{2} \mathrm{Ph} \\
& 13 \quad 18
\end{aligned}
$$

allylbenzene (16) (eq 9). Abstraction of a hydrogen atom from 9 by a benzyl radical

$$
17 \longrightarrow \underset{15}{\mathrm{PhCH}_{2} \mathrm{CH}}=\mathrm{CH}_{2}+\cdot \mathrm{CH}_{2} \mathrm{Ph}
$$

forms toluene (11) and radical 16 or 17 (eq 6, 7) and abstraction of a hydrogen atom from 9 by radical 18 forms ethylbenzene (14) and radical 16 or 17 (eq 10).

$$
18+9 \longrightarrow 16+17+\underset{14}{\mathrm{CH}_{3} \mathrm{CH}_{2} \mathrm{Ph}}
$$

wo other minor products are butylbenzene (19) and diphenylmethane (20). A reasonab. pathway to these products is addition of a benzyl radical to a phenyl ring of 9 to form radical 21 followed by decomposition of radical 21 to the 4-phenylbutyl radical (22) and 20 (eq 11). Abstraction of a hydrogen atom by radical 22 from 9 gives 19 and radical 16 or 17 (eq 12).

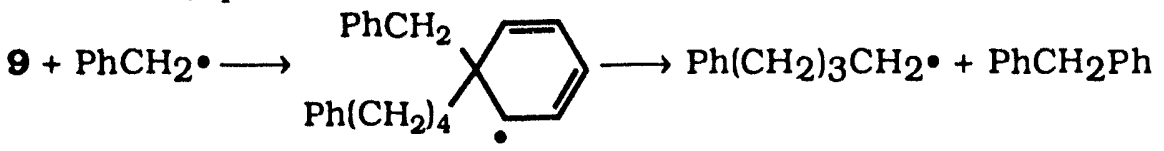

$$
\begin{aligned}
& 21 \\
& 22 \\
& 20 \\
& 9+22 \longrightarrow \mathrm{PhCH}_{2} \mathrm{CH}_{2} \mathrm{CH}_{2} \mathrm{CH}_{3}+16+17
\end{aligned}
$$

The detection of increasing amounts of 11 with higher pyrolysis temperatures and the observation of minor products 13, 14, 19, and 20 indicate some induced decomposition of $\boldsymbol{\theta}$ is occurring. However, these reactions occur to a significant extent only at high conversion where a high concentration of benzyl radicals is expected. 


\section{CONCLUSION}

In conclusion, our results show that the major reaction of the 3-phenylpropyl radicals (8) in the gas-phase at high temperature is cleavage of the $\beta$ carbon-carbon bond to produce ethylene and benzyl radical; loss of a $\beta$ hydrogen atom to form allylbenzene (16) and cyclization to form indan (12) are minor reactions under these conditions. Thus, the small amount of $\beta$ carbon-carbon bond cleavage of diradical 3 appears to be characteristic of that system, rather than a consequence of the method of generation. Apparently for diradical 3, the two reactions which involve interaction of the two radical sites, coupling to form 1 and disproportionation to form 7 , are much faster than $\beta$ carbon-carbon bond cleavage. 


\section{EXPERDMENTAL}

\section{General Procedures}

\section{Methods and materlals}

Some general methods have been described previously. $8{ }^{1}{ }_{\text {H NMR spectra were }}$ recorded on a Nicolet NT-300 spectrometer. GCMS were performed on a Finnegan 4000 mass spectrometer. All materials were commerclally avallable and used as recelved, except where indicated.

1,4-Diphenylbutane (9) 1,4-Diphenylbutane was prepared as previously described. $6 \mathrm{a} \operatorname{mp~} 51-53{ }^{\circ} \mathrm{C} ;{ }^{1} \mathrm{H} \mathrm{NMR}\left(\mathrm{CDCl}_{3}\right) \delta 7.30-7.12(\mathrm{~m}, 10 \mathrm{H}), 2.68-2.57(\mathrm{~m}, 4 \mathrm{H})$, 1.74-1.62 (m, $4 \mathrm{H}$ ) llit. 9 1 $_{\text {H NMR }} \delta 7.05$ (s, 5 H), 2.60 (m, 2 H), 1.65 (m, 2 H)]: GCMS (EI, $70 \mathrm{eV}$ ) m/e (\% base peak) 210 (32.4), 92 (53.1), 91 (100) [11t. ${ }^{9}$ GCMS (EI, $70 \mathrm{eV}$ ) m/e (\% base peak) 210 (27.5), 92 (57), 91 (100)).

Flash vacuum pyrolysis Flash vacuum pyrolysis (FVP) was performed as previously described. 1,10

Product analysis FVP reaction mixtures were analyzed by capillary gas chromatography on a Hewlett-Packard HP5840A gas chromatograph equipped with a 30-m (0.25- $\mu \mathrm{m}$ film thickness) DB-1701 capillary column using the analytical procedure previously described. ${ }^{1}$ 


\section{REFERENCES}

(1) Malandra, J. L.: Zhu, J.; Lee, S.-K.; Spurlin, S. R.; Tunkel, J. L.; Fischer, D. R.; Yeung, E. S.: Trahanovsky, W. S., manuscript in preparation. (Paper 1, this dissertation]

(2) (a) Berman, M. R.: Comita, P. B.: Moore, C. B.: Bergman, R. G. J. Amer. Chem. Soc. 1980, 102, 5692. (b) Comita, P. B.; Berman, M. R.; Moore, B. C.; Bergman, R. G. J. Phys. Chem. 1981, 85, 3266.

(3) Martin. N.; Seoane, C.: Hanack, M. Org. Prep. Proc. Int. 1991, 23, 239.

(4) Malandra, J. L.; Trahanovsky, W. S., manuscript in preparation. (Paper 2, this dissertation!

(5) Poutsma, M. L. A Review of Thermolysis Studies of Model Compounds Relevant to Processing of Coal: ORNL/TM-10673. Oak Ridge National Laboratory. Oak Ridge, TN 37831. This review is avallable from National Technical Information Service, U. S. Dept. of Commerce, 5285 Port Royal Rd., Springfield, VA 22161.

(6) Trahanovsky, W. S.: Ong, C. C. J. Amer. Chem. Soc. 1970, $92,7174$.

(7) (a) Poutsma, M. L.: Dyer, C. W. J. Org. Chem. 1982, 47, 4903. (b) Hung, M.-H.; Stock, L. M. Fuel 1982, 61, 1161. (c) King, H.-H.; Stock, L. M. Fuel 1984, 63, 810.

(8) (a) Trahanovsky, W. S.; Cassady, T. J.: Woods, T. L. J. Amer. Chem. Soc, 1981. 103, 6691. (b) Chou, C.-H.: Trahanovsky, W. S. J. Amer. Chem. Soc. 1986. 108. 4138.

(9) Rupprecht, R.; Zllliox, J.-G.; Franta, E.; Brossas, J. Eur. Polym. J. 1979, 15, 11.

(10) (a) Trahanovsky, W. S.; Ong, C. C.: Pataky, J. G.; Weitl, F. L.; Mullen, P. W.; Clardy, J. C.: Hansen, R. S. J. Org. Chem. 1971, 36, 3575. Commercial apparatus is available from Kontes Scientific Glassware, Vineland, NJ 08360. (b) For review, see Brown, R. C. F. Pyrolysis Methods in Organic Chemistry: Academic: New York, 1980, Chapter 2. 


\section{APPENDIX}

\section{SUPPLEMENTARY DATA TABLE}

Table A-I. Products and recovered starting material, total recovery of material, and conversion from the FVP of 1.4-diphenylbutane (9) at various oven temperatures $a, b$

\begin{tabular}{|c|c|c|c|c|c|}
\hline \multirow[b]{2}{*}{ entry } & \multicolumn{5}{|c|}{ yield, $\% c$} \\
\hline & $700^{\circ} \mathrm{C}$ & $750^{\circ} \mathrm{C}$ & $800^{\circ} \mathrm{C}$ & $850^{\circ} \mathrm{C}$ & $900^{\circ} \mathrm{C}$ \\
\hline toluene (11) & - & 0.08 & 0.75 & 6.38 & 11.16 \\
\hline ethylbenzene (14) & - & - & 0.08 & 0.71 & 1.46 \\
\hline styrene (13) & - & 0.10 & 0.56 & 1.87 & 2.33 \\
\hline allylbenzene (15) & - & - & 0.15 & 0.39 & 0.43 \\
\hline butylbenzene (19) & 0.13 & 0.23 & 0.35 & 0.41 & 0.46 \\
\hline indan (12) & - & 0.13 & 0.79 & 1.94 & 2.15 \\
\hline indene & - & - & 0.06 & 0.11 & 0.18 \\
\hline BA & - & $d$ & $d$ & $d$ & $d$ \\
\hline diphenylmethane (20) & - & - & 0.04 & 0.28 & 0.76 \\
\hline 1.2-diphenylethane (10) & 1.63 & 7.82 & 30.44 & 62.93 & 71.86 \\
\hline BB & - & - & $e$ & $e$ & $e$ \\
\hline $\mathrm{BC}$ & - & - & - & - & $d$ \\
\hline $\mathrm{BD}$ & $d$ & $d$ & $d$ & $d$ & - \\
\hline$B E$ & - & - & - & - & $d$ \\
\hline 1.4-diphenylbutane (9) & 98.24 & 91.09 & 65.73 & 23.43 & 7.13 \\
\hline $\mathrm{BF}$ & - & - & $d$ & $d$ & $d$ \\
\hline
\end{tabular}

Table A-I continues on next page 
Table A-I. Continued

\begin{tabular}{|c|c|c|c|c|c|}
\hline \multirow[b]{2}{*}{ entry } & \multicolumn{5}{|c|}{ yield. $\% c$} \\
\hline & $700^{\circ} \mathrm{C}$ & $750^{\circ} \mathrm{C}$ & $800^{\circ} \mathrm{C}$ & $850^{\circ} \mathrm{C}$ & $900^{\circ} \mathrm{C}$ \\
\hline $\mathrm{BG}-196\left[\mathrm{C}_{15} \mathrm{H}_{16}\right]$ & - & 0.06 & 0.32 & 0.32 & 0.40 \\
\hline $\mathrm{BH}-196\left[\mathrm{C}_{15} \mathrm{H}_{16}\right]$ & - & - & 0.09 & 0.08 & 0.11 \\
\hline $\mathrm{BI}-196\left[\mathrm{C}_{15} \mathrm{H}_{16}\right]$ & - & 0.06 & 0.25 & 0.19 & 0.30 \\
\hline BJ & - & - & $d$ & - & - \\
\hline BK & - & - & - & $d$ & - \\
\hline$B L$ & - & $d$ & $d$ & - & $d$ \\
\hline $\mathrm{BM}$ & - & - & - & $d$ & $d$ \\
\hline $\mathrm{BN}-272\left[\mathrm{C}_{2}{ }_{1} \mathrm{H}_{2} \mathrm{O}\right]$ & - & 0.10 & 0.11 & 0.26 & 0.29 \\
\hline $\mathrm{BO}$ & - & - & - & - & $d$ \\
\hline $\mathrm{BP}$ & - & - & - & - & $d$ \\
\hline $\mathrm{BQ}-272\left[\mathrm{C}_{2}{ }_{1} \mathrm{H}_{20} \mathrm{O}\right.$ & - & 0.08 & - & 0.08 & 0.13 \\
\hline $\mathrm{BR}-272\left[\mathrm{C}_{2}{ }_{1} \mathrm{H}_{2} \mathrm{O}\right]$ & - & 0.26 & 0.28 & 0.62 & 0.84 \\
\hline recovery $f$ & 98.94 & 98.55 & 96.36 & 94.01 & 85.47 \\
\hline conversion $g$ & 1.76 & 8.91 & 34.27 & 76.57 & 92.87 \\
\hline
\end{tabular}

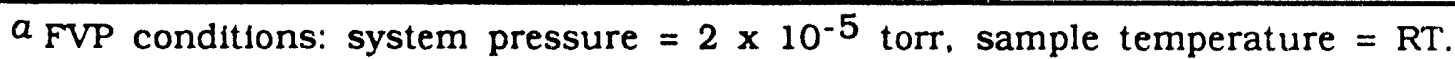
$b$ Amounts determined by GC with a known quantity of triphenylmethane added as standard. Data represent the average of triplicate runs. Products identified by comparison with authentic samples or those that could be identified by retention time and GCMS are indicated by name. Products that were identified by GCMS only are indicated by code: $X Y-n n n$, where ' $X$ ' corresponds to the system studied ( $B=$ pyrolysis of 9 ), $Y$ to the individual unknown product (A, B, C, etc.), and ' $n$ nn' to the nominal mass. ${ }^{c}$ Moles of product divided by total moles of recovered material. $d$ Product which constitutes $\leq 0.30 \%$ total area by GC. $e^{e}$ Product which constitutes between $0.35 \%$ to $0.90 \%$ total area by GC. $\int$ Total moles of recovered material divided by moles of starting material used. $g$ Total moles of recovered material minus moles of recovered starting material divided by total moles of recovered material. 
PAPER 5. THE FLASH VACUUM PYROLYSIS OF O-ALLYLTOLUENE,

O-(3-BUTENYL)TOLUENE AND O-(4-PENTENYL)TOLUENE 


\section{INTRODUCTION}

In our study of the gas-phase decomposition of tetralin (1), ${ }^{1}$ flow pyrolysis was used to limit bimolecular and heterogeneous surface reactions. Under these conditions, we found that o-allyltoluene (4) was one of the primary decomposition products, with 1.2-dihydronaphthalene (2) and benzocyclobutene (3). It was previously known (Scheme I) that, at higher temperatures, 2 would be converted to naphthalene (5) and 3 to styrene (6). The fate of 4 had not been previously explored. We pyrolyzed 4 under flow conditions and found that 2-methylindan (7) was formed and that 7 could be further pyrolyzed to indene (8) at higher temperatures.

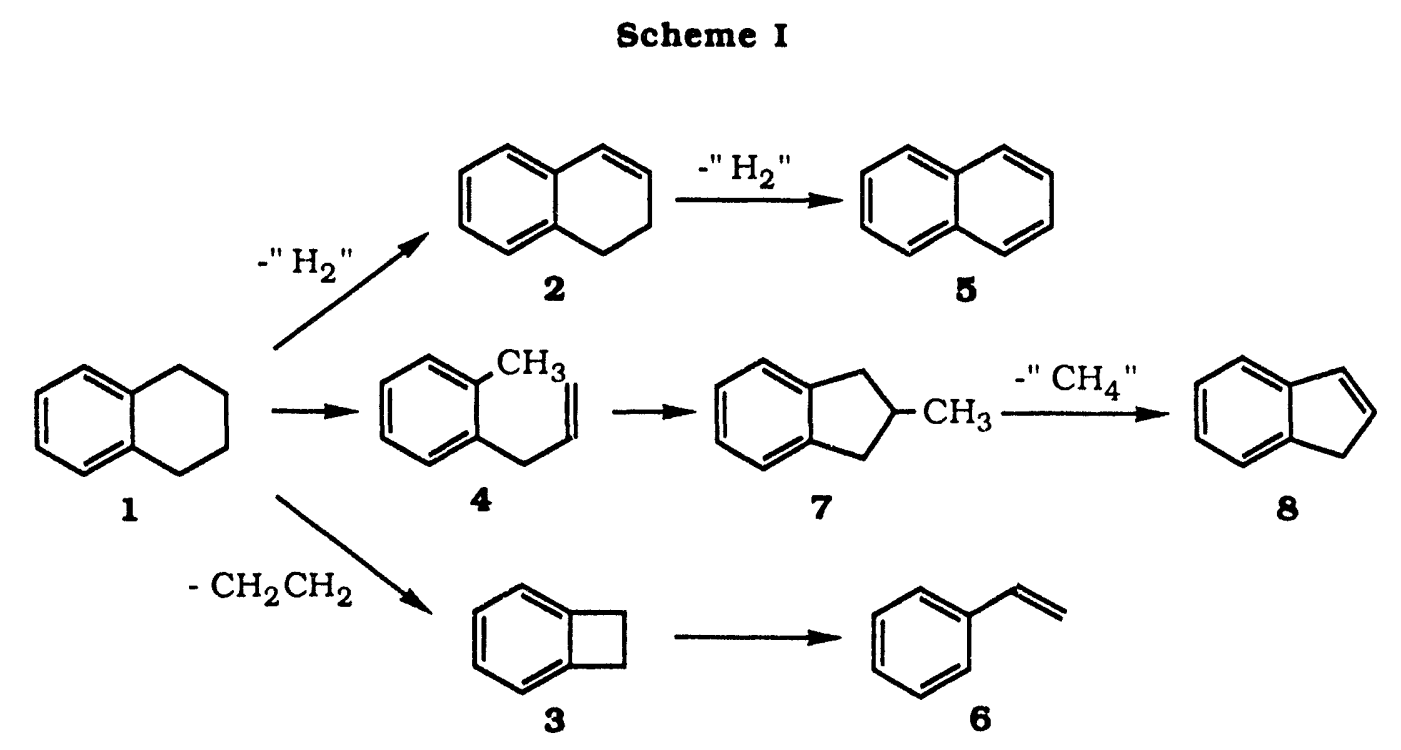


In this study, we have examined the flash vacuum pyrolysis (FVP) of 4 in order to determine if the conversion to $\mathbf{7}$ and 8 will occur under standard FVP conditions. The FVP of two homologous compounds, o-(3-butenyl)toluene (9) and o-(4-pentenyl)toluene

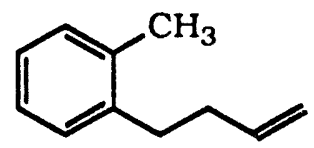

$\boldsymbol{9}$

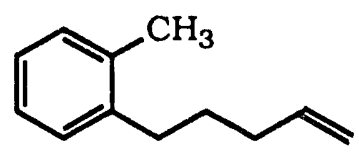

10

(10), was also studied for comparison purposes. 


\section{RESULTS}

The results of the FVP of 0 -allyltoluene (4) at 0.10 torr $\left(700-900^{\circ} \mathrm{C}\right)$ are presented in Table I. The major products are 2 -methylindan (7) and indene (8). Small amounts $(<4 \%)$ of tetralin (1), 1,2-dihydronaphthalene (2), and naphthalene (5) are also produced at $700-800^{\circ} \mathrm{C}$. At $900^{\circ} \mathrm{C}$, ca. $8 \% \mathrm{~s}$ is formed.

The FVP of o-(3-butenyl)toluene (9) under similar conditions produces 1,2-di(o-tolyl)ethane (11) in good yield (ca. 40\%) at $700-800^{\circ} \mathrm{C}$. At $900{ }^{\circ} \mathrm{C}$. significant amounts (ca. 10-20\%) of o-xylene (12), benzocyclobutene (3), o-ethyltoluene (13), and styrene (6) are formed.

The FVP of o-(4-pentenyl)toluene (10) results in the formation of o-methylstyrene (14). Numerous side products, each produced in small amounts, were detected at high conversion $\left(900^{\circ} \mathrm{C}\right)$. These results are presented in Table III. 
Table 1. Products and recovered starting material from the FVP of $o$-allyltoluene (4) at various oven temperatures $a, b$

\begin{tabular}{|c|c|c|c|}
\hline \multirow[b]{2}{*}{ entry } & \multicolumn{3}{|c|}{ yield, \% $c$} \\
\hline & $700^{\circ} \mathrm{C}$ & $800^{\circ} \mathrm{C}$ & $900^{\circ} \mathrm{C}$ \\
\hline o-allyltoluene (4) $d$ & 90.9 & 45.4 & 6.6 \\
\hline 2-methylindan (7) & 4.1 & 25.3 & 14.1 \\
\hline indene $(8)$ & 0.8 & 6.9 & 32.0 \\
\hline tetralin (1) & 0.3 & 2.7 & 3.3 \\
\hline 1,2-dihydronaphthalene (2) & 0.6 & 1.4 & 1.1 \\
\hline naphthalene (5) & - & 1.0 & 8.1 \\
\hline other products & $3.3^{e}$ & $17.3^{e}$ & $34.9^{e}$ \\
\hline recovery $f$ & 83.3 & 88.8 & 72.8 \\
\hline conversion $g$ & 9.1 & 54.6 & 93.4 \\
\hline \multicolumn{4}{|c|}{ 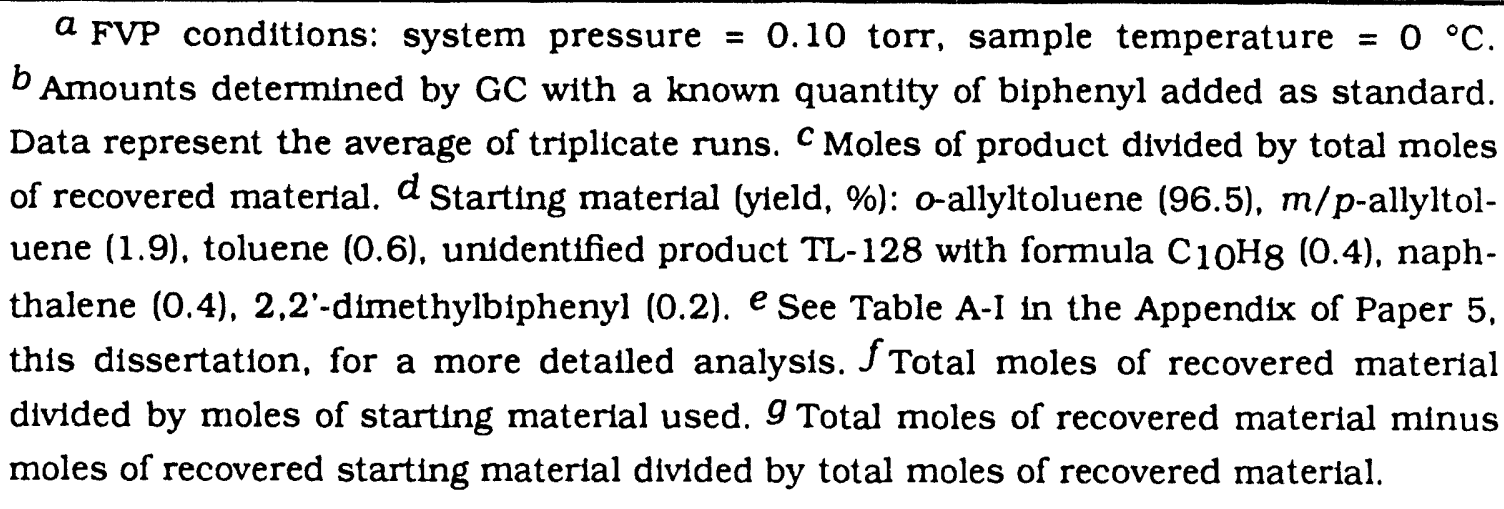 } \\
\hline
\end{tabular}


Table II. Products and recovered starting materlal from the FVP of o-(3-butenyl)toluene (9) at various oven temperatures $a, b$

\begin{tabular}{|c|c|c|c|}
\hline \multirow[b]{2}{*}{ entry } & \multicolumn{3}{|c|}{ yleld, \% $c$} \\
\hline & $700^{\circ} \mathrm{C}$ & $800^{\circ} \mathrm{C}$ & $900^{\circ} \mathrm{C}$ \\
\hline o-(3-butenyl)toluene (9) $d$ & 64.2 & 41.7 & 15.9 \\
\hline 1,2-di(o-tolyl)ethane (11) & 34.4 & 39.4 & 7.6 \\
\hline o-xylene (12) & 0.4 & 4.7 & 18.6 \\
\hline benzocyclobutene (3) & 0.4 & 3.5 & 15.2 \\
\hline o-ethyltoluene (13) & - & 3.0 & 10.4 \\
\hline styrene (6) & - & 0.5 & 6.8 \\
\hline other products & $0.6^{e}$ & $7.3^{e}$ & $25.5^{e}$ \\
\hline recovery $f$ & 97.8 & 88.7 & 110.0 \\
\hline conversion $g$ & 35.8 & 58.3 & 84.1 \\
\hline
\end{tabular}


Table III. Products and recovered starting material from the FVP of 0 -(4-pentenyl)toluene (10) at varlous oven temperatures $a, b$

\begin{tabular}{lccc}
\hline & \multicolumn{3}{c}{ yield. $\% \mathrm{c}$} \\
\cline { 2 - 4 } entry & $600^{\circ} \mathrm{C}$ & $700^{\circ} \mathrm{C}$ & $800{ }^{\circ} \mathrm{C}$ \\
\hline o-(4-pentenyl)toluene (10) $d$ & 90.4 & 52.9 & 3.0 \\
o-methylstyrene (14) & 1.5 & 30.6 & 59.8 \\
other products & $8.1 e$ & $16.5 e$ & $37.0 e$ \\
& & & \\
recovery $f$ & 96.2 & 86.6 & 70.4 \\
conversion $g$ & 9.6 & 47.1 & 97.0 \\
\hline
\end{tabular}

$a$ FVP conditions: see Table II, footnote $a .^{b}$ See Table I, footnote $b .{ }^{c}$ See Table I, footnote $c{ }^{d}$ Starting material (yleld, \%): o-(4-pentenyl)toluene (92.4), 2,2'-dimethylbiphenyl (7.6), unidentified impurity PC which constitutes $<0.35 \%$ total area by GC. $e$ See Table A-III in the Appendix of Paper 5, this dissertation, for a more detalled analysis. $f$ See Table I, footnote $f . g$ See Table I, footnote $g$. 


\section{Discussion}

FVP of 0 -allyltoluene (4) clearly results in the formation of 2-methylindan (7), which then further decomposes to indene (8). Even at $900^{\circ} \mathrm{C}, 4,7$ and 8 constitute over $50 \%$ of the products. These FVP results are similar to the flow pyrolysis results obtained earlier. ${ }^{1}$ However, the FVP of 4 results in the formation of more side products at high temperature than flow pyrolysis.

We propose that 7 is produced by a two-step mechanism involving diradical 15 formed by an intramolecular hydrogen atom transfer. Although there are examples of

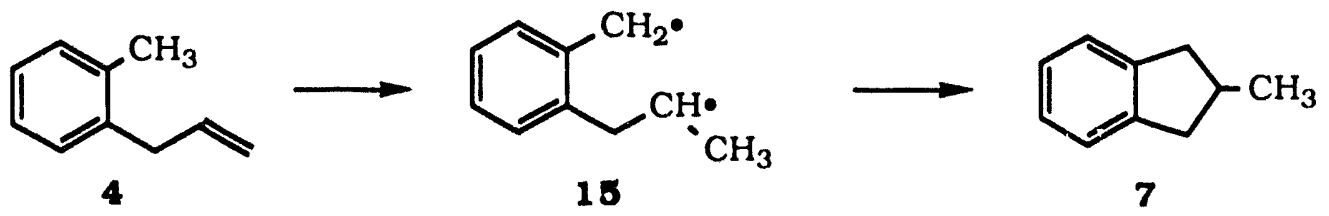

the formation of hydrocarbon radicals by intramolecular hydrogen atom transfers, ${ }^{2}, 3$

$$
\mathrm{RH}+\mathrm{R}^{\prime} \mathrm{H} \longrightarrow \mathrm{R}^{\bullet}+\mathrm{R}^{\prime} \mathrm{H}_{2}
$$

we are not aware of any intramolecular examples of this reaction. The calculated 4 enthalples of formation of radicals 4 and 16 have a $\Delta \mathrm{H}^{\circ}$ of $45 \mathrm{kcal} \mathrm{mol}^{-1}$. This indicates that the conversion of 4 to 7 is reasonable at FVP temperatures $\geq 700^{\circ} \mathrm{C}$.

Conversion of 2 -methylindan (7) to indene (8) at higher temperatures is readily explained by the loss of a methyl group form 7 to form the 2-indanyl radical which would rapidly lose a $\beta$ hydrogen atom to give 8.5

The FVP of 4 also gives some tetralin (1) and this may arise from the 1.6-diradical (I6) produced by a hydrogen atom transfer reaction to the internal olefinic<smiles>C=CCc1ccccc1C</smiles>

4

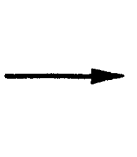

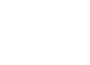
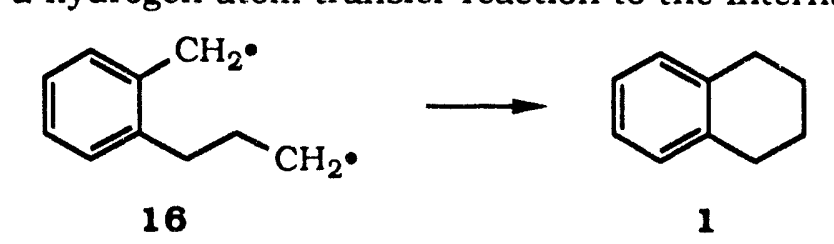
carbon atom. The 1,2-dihydronaphthalene (2), naphthalene (B), and other products may simply be products of the secondary pyrolysis of 1 .

In the FVP of o-(3-butenyl)toluene (9), the main reaction is homolytic cleavage of the weak benzylic-allylic carbon-carbon bond (Table II). The dimerization of o-methylbenzyl radicals (17), produced from this bond cleavage, results in the formation of 1,2-di(o-tolyl)ethane (11). The allyl radicals (18) should dimerize to form 1,5-hexadiene<smiles>C=CCCc1ccccc1C</smiles>

$\boldsymbol{9}$

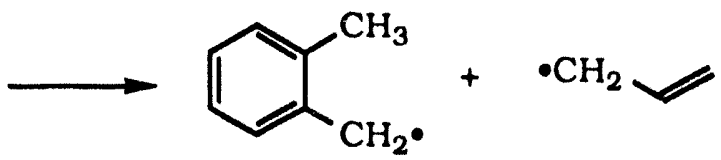<smiles>CCc1ccccc1C</smiles>

11
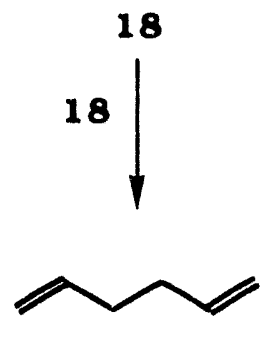

19

(19), however, this product was not detected due to its high volatility. At $900{ }^{\circ} \mathrm{C}$, the major products are o-xylene (12), benzocyclobutene (3), o-ethyltoluene (13), and styrene (6). These products all appear to be formed from 17.

The results of the pyrolysis of o-(4-pentenyl)toluene (10) are presented in Table III. The main product from the pyrolysis of o-(4-pentenyl)toluene (10) is o-methylstyrene (14) formed by a retro-ene reaction. Numerous minor side products are formed at high temperature $\left(800^{\circ} \mathrm{C}\right)$.

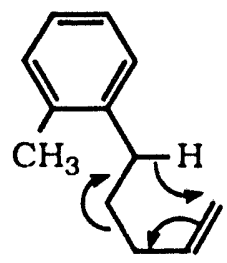

10

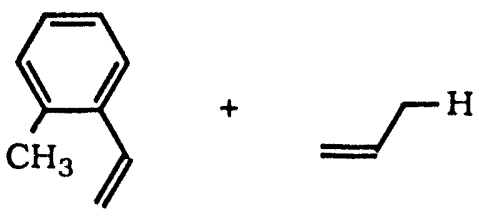

14 
The $\Delta H^{\ddagger}$ for the conversion of 4 to 7 and 8 (Table I) was estimated from the FVP data for 9 (Table II) and 10 (Table III) by the method of Schless. 6 The 50\% conversion temperature (T 50\%) was determined for 4,9 and 10 from a linear least squares line of a temperature vs. conversion plot (Figure 1. Table IV). The $\Delta \mathrm{H}^{\ddagger}$ for the homolytic bond cleavage of 9 was calculated ${ }^{4}\left(\Delta H^{\ddagger} \sim \Delta H^{0}\right)$ and the $\Delta H^{\ddagger}$ for the retro-ene reaction of 10 was estimated from the previously studied retro-ene reaction of 1.6-heptadiene ${ }^{7}$ (Table IV). In this way, the $\Delta H^{\ddagger}$ for the conversion of 4 to 7 and 8 was estimated to be ca. 64 kcal mol-1 (Table IV).

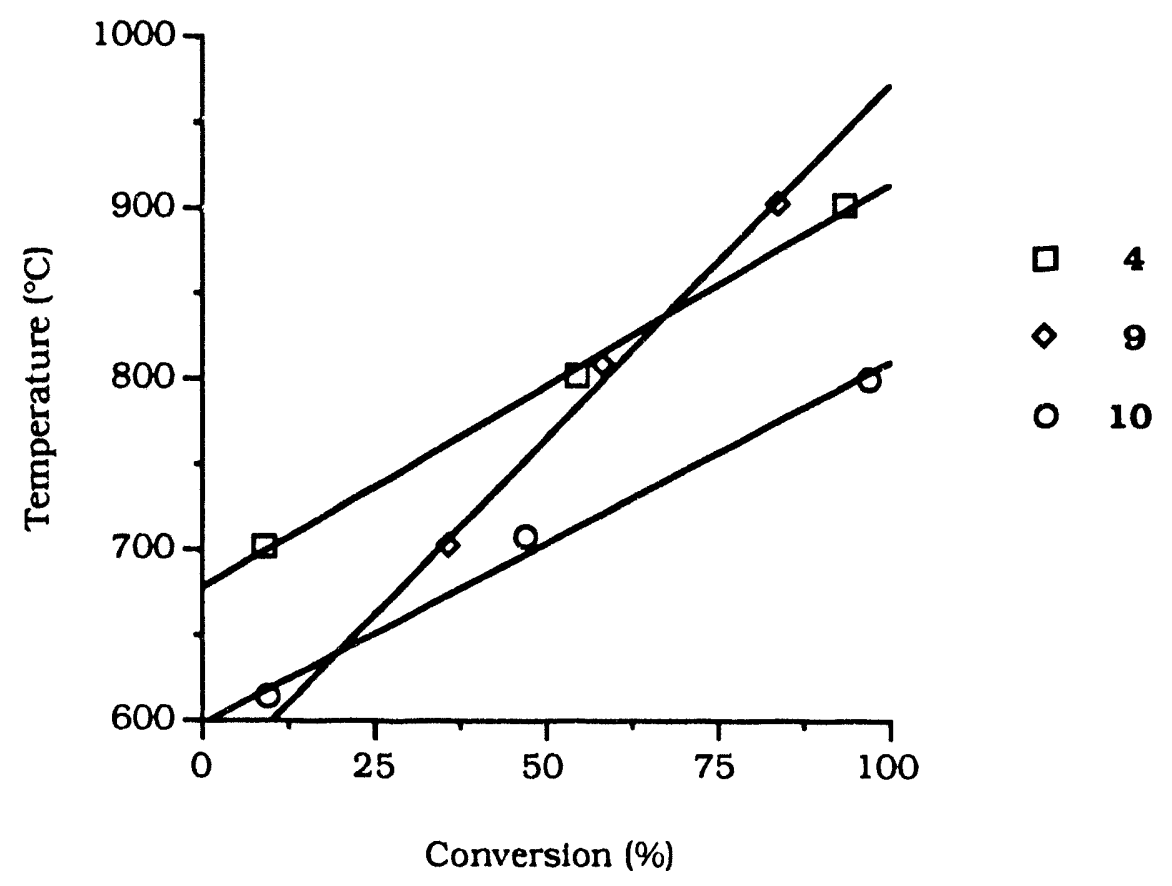

Figure 1. Plot of temperature vs. conversion for the FVP of 0 -allyltoluene (4). o-(3-butenyl)toluene (9), and o-(4-pentenyl)toluene (10) (system pressure, $0.10-0.010$ torr; sample temperature, $0^{\circ} \mathrm{C}$ ) 
Table IV. Linear least squares line for temperature vs. conversion and $\Delta \mathrm{H}^{\ddagger}$ for the FVP of o-allyltoluene (4), o-(3-butenyl)toluene (9), and o-(4-pentenyl)toluene (10)

\begin{tabular}{|c|c|c|c|c|c|}
\hline \multirow[b]{2}{*}{ entry } & \multicolumn{3}{|c|}{$\begin{array}{l}\text { linear least squares line } \\
\text { temperature vs. conversion }\end{array}$} & \multirow[b]{2}{*}{$\begin{array}{c}\mathrm{T} 50 \% \\
{ }^{\circ} \mathrm{C}\end{array}$} & \multirow[b]{2}{*}{$\begin{array}{c}\Delta \mathrm{H}^{\ddagger}, \\
\text { kcal mol-1 }\end{array}$} \\
\hline & $\begin{array}{l}\text { slope, } \\
{ }^{\circ} \mathrm{C} \%-1\end{array}$ & $\begin{array}{c}y \text {-Intercept, } \\
{ }^{\circ} \mathrm{C}\end{array}$ & $r^{2}$ & & \\
\hline o-allyltoluene (4) & 2.37 & 677 & 0.998 & 796 & $64^{a}$ \\
\hline o-(3-butenyl)toluene (9) & 4.13 & 559 & 0.995 & 765 & $58.4^{b}$ \\
\hline o-(4-pentenyl)toluene $(10)$ & 2.12 & 598 & 0.993 & 704 & $47.5^{c}$ \\
\hline
\end{tabular}




\section{CONCLUSION}

We have observed the conversion of o-allyltoluene (4) to 2-methylindan (7) and indene (8) under both FVP and flow pyrolysis conditions. We belleve the 4 to 7 reaction involves intramolecular benzylic hydrogen atom transfer to the double bond to form

diradical 16. The calculated $\Delta \mathrm{H}^{\circ}$ for this reaction is $45 \mathrm{kcal} \mathrm{mol}^{-1}$. We have also pyrolyzed o-(3-butenyl)toluene (9) which undergoes homolytic bond cleavage and o-(4-pentenyl)toluene (10) which forms o-methylstyrene (14) through a retro-ene reaction. From the $\Delta H^{\ddagger}$ of these reactions, we estimate the $\Delta H^{\ddagger}$ for the 4 to 7 conversion is $65 \mathrm{kcal} \mathrm{mol}^{-1}$. 


\section{EXPERIMENTAL}

\section{General Procedures}

\section{Methods and materials}

Some general methods have been described previously. $8{ }^{1} \mathrm{H}$ NMR spectra were recorded on a Nicolet NT-300 spectrometer. FTIR spectra were obtained on an IBM IR/98 spectrophotometer. GCMS were performed on a Finnegan 4000 mass spectrometer. HRMS were performed on a Kratos MS-50 mass spectrometer. All materials were commercially available and used as received, except where indicated.

o-Allyltoluene (4) o-Allyltoluene (4) was prepared by previously published procedure. ${ }^{9}{ }^{1} \mathrm{H} \mathrm{NMR}\left(\mathrm{CDCl}_{3}\right) \delta 7.12(\mathrm{~s}, 4 \mathrm{H}), 5.94$ (qt, $\left.J_{\mathrm{q}}=10.3 \mathrm{~Hz}, J_{\mathrm{t}}=6.4 \mathrm{~Hz}, 1 \mathrm{H}\right), 5.04$ (dq, $\left.J_{\mathrm{d}}=10.1 \mathrm{~Hz}, J_{\mathrm{q}}=1.6 \mathrm{~Hz}, 1 \mathrm{H}\right), 4.98\left(\mathrm{dq}, J_{\mathrm{d}}=17.0 \mathrm{~Hz}, J_{\mathrm{q}}=1.7 \mathrm{~Hz}, 1 \mathrm{H}\right.$ ), $3.36\left(\mathrm{dt}, J_{\mathrm{d}}=\right.$ $\left.6.3 \mathrm{~Hz}, J_{\mathrm{t}}=1.6 \mathrm{~Hz}, 1 \mathrm{H}\right), 2.28(\mathrm{~s}, 3 \mathrm{H})$ [lit. $10 \mathrm{~b} 1_{\mathrm{H} \mathrm{NMR}}\left(\mathrm{CCl}_{4}\right) \delta 6.94(\mathrm{~s}, 4 \mathrm{H}), 5.79$ (qt, $J_{\mathrm{q}}=$ $\left.11.3 \mathrm{~Hz}, J_{\mathrm{t}}=6.5 \mathrm{~Hz}, 1 \mathrm{H}\right), 4.93(\mathrm{~m}, 1 \mathrm{H}), 4.79\left(\mathrm{dq}, J_{\mathrm{d}}=11.3 \mathrm{~Hz}, J_{\mathrm{q}}=2.1 \mathrm{~Hz}, 1 \mathrm{H}\right), 3.24(\mathrm{dt}$, $\left.J_{\mathrm{d}}=6.0 \mathrm{~Hz}, J_{\mathrm{t}}=1.8 \mathrm{~Hz}, 2 \mathrm{H}\right), 2.20$ (s, 3H)]: GCMS $(70 \mathrm{eV}) \mathrm{m} / \mathrm{e}(\%$ base peak) $132(77.5)$, 117 (100), 115 (42.3), 91 (35.6), 65 (31.6) [lit. $9 \mathrm{~b}$ MS (50 ev) m/e 132 (parent), 117 (base)].

o-(3-Butenyl)toluene (9) Allylmagnesium bromide $(25 \mathrm{~mL}, 1.0 \mathrm{M}$ solution in ether, $0.025 \mathrm{~mol}$ ) was added dropwise to a solution of $\alpha$-chloro-o-xylene ( $3.5 \mathrm{~g}, 0.025$ mol. ca. $3.3 \mathrm{~mL})$ in ether $(15 \mathrm{~mL})$ at $0^{\circ} \mathrm{C}$. The reaction mixture was stirred at room temperature for $1 \mathrm{~h}$, quenched with $\mathrm{H}_{2} \mathrm{O}(50 \mathrm{~mL})$, and the phases separated. The aqueous phase was extracted with ether $(3 \times 50 \mathrm{~mL})$. The combined organic phases were washed with $\mathrm{H}_{2} \mathrm{O}(2 \times 50 \mathrm{~mL})$ and saturated $\mathrm{NaCl}(50 \mathrm{~mL})$, dried $\left(\mathrm{MgSO}_{4}\right)$, and the solvent removed in vacuo. HPLC purification ${ }^{1}$ yielded.o-(3-butenyl)toluene (1.9 g, 0.013 mol, $64 \%$ yield). ${ }^{1} \mathrm{H} \mathrm{NMR}\left(\mathrm{CDCl}_{3}\right) \delta 7.17-7.07(\mathrm{~m}, 4 \mathrm{H}), 5.84$ (qt, $J_{\mathrm{q}}=10.2 \mathrm{~Hz}, J_{\mathrm{t}}=6.6 \mathrm{~Hz}$. $1 \mathrm{H}$ ), 5.04 (dq, $J_{\mathrm{d}}=17.1 \mathrm{~Hz}, J_{\mathrm{q}}=1.5 \mathrm{~Hz}, 1 \mathrm{H}$ ), 4.98 (ddt, $J_{\mathrm{d}}=10.2 \mathrm{~Hz}, J_{\mathrm{d}}=1.8 \mathrm{~Hz}, J_{\mathrm{t}}=1.2$ 
$\mathrm{Hz}, 1 \mathrm{H}), 2.73-2.65(\mathrm{~m}, 2 \mathrm{H}), 2.37-2.27(\mathrm{~m}, J=7 \mathrm{~Hz}, 2 \mathrm{H}), 2.31$ (s, $3 \mathrm{H}) ; \mathrm{GCMS}(70 \mathrm{eV}) \mathrm{m} / e$ (\% base peak) 160 (16.4), 118 (78.4), 106 (33.8), 105 (100), 91 (40.7), 77 (26.7).

o-(4-Pentenyl)toluene (10) The following modified literature procedure 1 was used. Crushed $\mathrm{Mg}$ turnings $(0.36 \mathrm{~g}, 0.015 \mathrm{~mol}$ ) were added to THF (55 mL) under $\mathrm{Ar}$ atmosphere. 2-Bromotoluene (2.3 g. $0.013 \mathrm{~mol}, \mathrm{ca} .1 .6 \mathrm{~mL})$ was added and the mixture was stirred overnight. 5-Bromo-1-pentene $(2.0 \mathrm{~g}, 0.013 \mathrm{~mol}, \mathrm{ca} .1 .6 \mathrm{~mL})$ and $\mathrm{CuBr}(0.096$ g. $0.67 \mathrm{mmol}$ ) in HMPA $(5 \mathrm{~mL})$ were heated to $50-60^{\circ} \mathrm{C}$ for one-half $\mathrm{h}$. The Grignard reagent was transferred to an addition funnel and added dropwise to the warm HMPA solution. After the addition was complete, the reaction mixture was refluxed for $2 \mathrm{~h}$, added to a mixture of ice and $1 \mathrm{M} \mathrm{HCl}$ in a beaker, and extracted with ether $(3 \times 50 \mathrm{~mL})$. The combined ether fractions were washed with $\mathrm{H}_{2} \mathrm{O}(50 \mathrm{~mL})$, saturated $\mathrm{NaCl}(50 \mathrm{~mL})$, dried ( $\left.\mathrm{MgSO}_{4}\right)$, and the solvent removed in vacuo. Flash column chromatography on a silica gel column $(30 \times 100 \mathrm{~mm})$ with hexanes ydelded o-(4-pentenyl)toluene $(0.87 \mathrm{~g}, 5.4$ mmol, $40 \%$ yield). ${ }^{1} \mathrm{H}$ NMR $\left(\mathrm{CDCl}_{3}\right) \delta 7.15-7.05(\mathrm{~m}, 4 \mathrm{H}), 5.85$ (qt, $J_{\mathrm{q}}=10.2 \mathrm{~Hz}, J_{\mathrm{t}}=6.7$ $\mathrm{Hz}, 1 \mathrm{H}), 5.04\left(\mathrm{dq}, J_{\mathrm{d}}=17.1 \mathrm{~Hz}, J_{\mathrm{q}}=1.7 \mathrm{~Hz}, 1 \mathrm{H}\right), 4.98\left(\mathrm{ddt}, J_{\mathrm{d}}=10.2 \mathrm{~Hz}, J_{\mathrm{d}}=2.2 \mathrm{~Hz}, J_{\mathrm{t}}=\right.$ $1.2 \mathrm{~Hz}, 1 \mathrm{H}), 2.64-2.55$ (m, $2 \mathrm{H}), 2.30$ (s, $3 \mathrm{H}), 2.19-2.11(\mathrm{~m}, 2 \mathrm{H}), 1.71-1.65$ (m, $2 \mathrm{H}$ ) [lit. 12 $\left.1_{\mathrm{H} \mathrm{NMR}\left(\mathrm{CDCl}_{3}\right)} \delta 7.08(4 \mathrm{H}), 5.88(1 \mathrm{H}), 5.05(2 \mathrm{H}), 2.60(2 \mathrm{H}), 2.28(3 \mathrm{H}), 2.6-1.3(4 \mathrm{H})\right]$; GCMS (70 eV) m/e (\% base peak) 160 (16.4), 118 (78.4), 106 (33.8), 105 (100), 91 (40.7), 77 (26.7).

Flash vacuum pyrolysis Flash vacuum pyrolysis (FVP) was performed as previously described. 13

Product analysis FVP reaction mixtures were analyzed by capillary gas chromatography on a Hewlett-Packard HP5840A gas chromatograph equipped with a 30-m (0.25- $\mu \mathrm{m}$ film thickness) DB-1701 caplllary column using the analytical procedure previously described. 1 


\section{REFERENCES}

(1) Malandra, J. L.; Zhu, J.; Lee, S.-K.; Spurlin, S. R.; Tunkel, J. L.; Fischer, D. R.; Yeung, E. S.: Trahanovsky, W. S., manuscript in preparation. [Paper 1, this dissertation]

(2) Poutsma, M. L. A Review of Thermolysis Studies of Model Compounds Relevant to Processing of Coal; ORNL/TM-10673, Oak Ridge National Laboratory, Oak Ridge, TN 37831. This review is avallable from National Technical Information Service, U. S. Dept. of Commerce, 5285 Port Royal Rd., Springfield, VA 22161.

(3) (a) Franz, J. A.; Camaioni, D. M.; Beishline, R. R.; Dalling, D. K. J. Org. Chem. 1984, 49, 3563. (b) Blllmers, R.; Grifnth, L. L.; Stein. S. E. J. Phys. Chem. 1986. $90,517$.

(4) Benson, S. W. Thermochemical Kinetics, 2nd ed.; Wiley: 1976.

(5) Franz, J. A.; Camaioni, D. M. J. Org. Chem. 1980, 45, 5247.

(6) Schiess, P. Thermochimica Acta 1987, 112, 31.

(7) Egger, K. W.; Vitins, P. J. Amer. Chem. Soc. 1974, 96, 2714.

(8) (a) Trahanovsky, W. S.; Cassady, T. J.; Woods, T. L. J. Amer. Chem. Soc. 1981, 103, 6691. (b) Chou, C.-H.; Trahanovsky, W. S. J. Amer. Chem. Soc. 1986, 108 , 4138.

(9) Hurd, C. D.; Bollman, H. T. J. Amer. Chem. Soc. 1934, 56, 447.

(10) (a) Berman, M. R.; Comita, P. B.; Moore, C. B.; Bergman, R. G. J. Amer. Chem. Soc. 1980, 102, 5692. (b) Comita, P. B.; Berman, M. R.; Moore, B. C.; Bergman, R. G. J. Phys. Chem. 1981, 85, 3266.

(11) Nishimura, J.; Yamada, N.; Horluchi, E. U.; Ohbayash1, A.; Oku, A. Bull. Chem. Soc. Japan 1986, 59, 2035.

(12) Ellis-Davies, G. C. R.; Gilbert, A.; Heath, P.; Lane, J. C.; Warrington, J. V.; Westover, D. L. J. Chem. Soc., Perkin Trans. 2 1984, 1833. 
(13) (a) Trahanovsky, W. S.; Ong. C. C.: Pataky, J. G.; Weitl, F. L.; Mullen, P. W.; Clardy, J. C.; Hansen, R. S. J. Org. Chem. 1971, 36, 3575. Commercial apparatus is avallable from Kontes Scientific Glassware, Vineland, NJ 08360. (b) For review, see Brown, R. C. F. Pyrolysis Methods in Organic Chemistry; Academic: New York, 1980, Chapter 2. 


\section{APPENDIX}

\section{SUPPLEMENTARY DATA TABLES}

Table A-I. Products and recovered starting material, total recovery of material, and conversion from the FVP of 0 -allyltoluene (4) at various oven temperatures $a, b$

\begin{tabular}{|c|c|c|c|c|}
\hline \multirow[b]{2}{*}{ entry } & \multicolumn{4}{|c|}{ yield, $\% c$} \\
\hline & $\mathrm{RT}^{d}$ & $701^{\circ} \mathrm{C}$ & $802^{\circ} \mathrm{C}$ & $901^{\circ} \mathrm{C}$ \\
\hline toluene & 0.57 & - & 1.05 & 3.03 \\
\hline ethylbenzene & - & - & 0.55 & 1.92 \\
\hline$m / p$-xylene & - & - & 0.51 & 0.18 \\
\hline o-xylene (12) & - & - & 0.23 & 1.92 \\
\hline styrene (6) & - & - & 0.75 & 3.45 \\
\hline benzocyclobutene (3) & - & - & 0.35 & 1.19 \\
\hline allylbenzene & - & - & - & 0.26 \\
\hline propylbenzene & - & - & - & 0.12 \\
\hline o-ethyltoluene (13) & - & - & 1.46 & 0.94 \\
\hline $\mathrm{AA}-118\left[\mathrm{C}_{9} \mathrm{H}_{10} \mathrm{O}\right]$ & - & - & - & 0.09 \\
\hline o-methylstyrene (14) & - & 1.02 & 3.18 & 5.52 \\
\hline $\mathrm{AB}-118\left[\mathrm{C} 9 \mathrm{H}_{10} \mathrm{O}\right]$ & - & - & - & 0.29 \\
\hline benzaldehyde & - & - & - & 0.17 \\
\hline indan & - & - & - & 0.68 \\
\hline $\operatorname{trans}-\beta$-methylstyrene & - & - & - & 0.11 \\
\hline $\mathrm{m} / \mathrm{p}$-allyltoluene & 1.94 & 1.97 & 1.76 & 0.79 \\
\hline
\end{tabular}

Table A-I continues on next page 
Table A-I. Continued

\begin{tabular}{|c|c|c|c|c|}
\hline \multirow[b]{2}{*}{ entry } & \multicolumn{4}{|c|}{ yield, \% $c$} \\
\hline & $\mathrm{RT} d$ & $701^{\circ} \mathrm{C}$ & $802^{\circ} \mathrm{C}$ & $901^{\circ} \mathrm{C}$ \\
\hline o-allyltoluene (4) & 96.47 & 90.94 & 45.35 & 6.56 \\
\hline indene (8) & 一 & 0.83 & 6.86 & 31.98 \\
\hline 2-methylindan (7) & - & 4.09 & 25.34 & 14.08 \\
\hline 1-methylindan & - & - & 1.43 & 0.60 \\
\hline TD- $130\left[\mathrm{C}_{10} \mathrm{H}_{10}\right]$ & - & - & 0.14 & 0.92 \\
\hline TE-130 $\left[\mathrm{C}_{10} \mathrm{H}_{10}\right]$ & - & - & - & 0.11 \\
\hline o-methylbenzaldehyde & - & - & 0.28 & 0.15 \\
\hline$o-(1$-propenyl)toluene & - & - & 3.05 & 3.68 \\
\hline $\mathrm{TH}-130\left[\mathrm{C}_{10} \mathrm{H}_{10}\right]$ & - & - & - & 0.18 \\
\hline 3-methyl-1H-indene & - & - & 0.72 & 3.47 \\
\hline tetralin (1) & - & 0.32 & 2.74 & 3.28 \\
\hline 2-methyl-1H-indene & - & - & 0.42 & 0.73 \\
\hline $\mathrm{TK}-130\left[\mathrm{C}_{10} \mathrm{H}_{10} \mathrm{l}\right.$ & - & - & 1.20 & 2.43 \\
\hline 1,2-dihydronaphthalene (2) & - & 0.55 & 1.42 & 1.10 \\
\hline $\mathrm{TL}-128\left[\mathrm{C}_{10} \mathrm{H}_{8}\right]$ & 0.40 & - & - & 0.98 \\
\hline naphthalene (5) & 0.39 & - & 0.96 & 8.10 \\
\hline $\mathrm{TN}$ & - & - & - & $e$ \\
\hline TO- $148\left[\mathrm{C}_{11} \mathrm{H}_{16}\right]$ & - & - & - & 0.10 \\
\hline 2-methylnaphthalene & - & - & - & 0.17 \\
\hline 1-methylnaphthalene & - & - & - & 0.24 \\
\hline 2,2'-dimethylbiphenyl & 0.24 & 0.27 & 0.25 & 0.39 \\
\hline $\mathrm{AC}-182\left[\mathrm{C}_{14} \mathrm{H}_{14}\right]$ & - & - & - & 0.10 \\
\hline
\end{tabular}

Table A-I continues on next page 
Table A-I. Continued

\begin{tabular}{lcccc}
\hline & \multicolumn{4}{c}{ yield, \% $\mathrm{c}$} \\
\cline { 2 - 5 } entry & $\mathrm{RT}^{d}$ & $701{ }^{\circ} \mathrm{C}$ & $802{ }^{\circ} \mathrm{C}$ & $901^{\circ} \mathrm{C}$ \\
\hline recovery $f$ & 94.62 & 83.28 & 88.78 & 72.79 \\
conversion $g$ & $d$ & 9.06 & 54.65 & 93.44 \\
\hline
\end{tabular}

$a$ FVP conditions: system pressure $=0.10$ torr, sample temperature $=0{ }^{\circ} \mathrm{C}$. $b$ Amounts determined by GC with a known quantity of biphenyl added as standard. Data represent the average of triplicate runs. Products identified by comparison with authentic samples or those that could be identified by retention time and GCMS are indicated by name. Products that were identified by GCMS only are indicated by code: $X Y-n n n$, where ' $X$ ' corresponds to the system studied $(A=$ pyrolysis of $4, T=$ pyrolysis of 1 ), $Y$ to the individual unknown product (A, B, C, etc.), and 'nnn' to the nominal mass. $c$ Moles of product divided by total moles of recovered material. $d$ Starting material purity assay. $e^{e}$ Unidentified product which constitutes $\leq 0.25 \%$ total area by GC. $f$ Total moles of recovered material divided by moles of starting material used. $g$ Total moles of recovered material minus moles of recovered starting material divided by total moles of recovered material. 
Table A-II. Products and recovered starting material, total recovery of material, and conversion from the FVP of o-(3-butenyl)toluene (9) at various oven temperatures $a, b$.

\begin{tabular}{|c|c|c|c|c|}
\hline \multirow[b]{2}{*}{ entry } & \multicolumn{4}{|c|}{ yield, \%c } \\
\hline & $\mathrm{RT} d$ & $702^{\circ} \mathrm{C}$ & $808^{\circ} \mathrm{C}$ & $902^{\circ} \mathrm{C}$ \\
\hline toluene & - & - & - & 2.29 \\
\hline ethylbenzene & - & - & - & 1.59 \\
\hline$m / p$-xylene & - & - & - & 0.75 \\
\hline$o$-xylene (12) & - & 0.40 & 4.70 & 18.58 \\
\hline styrene (6) & - & - & 0.46 & 6.80 \\
\hline benzocyclobutene (3) & - & 0.36 & 3.51 & 15.24 \\
\hline allylbenzene & - & - & - & 0.23 \\
\hline propylbenzene & - & - & - & 0.32 \\
\hline o-ethyltoluene (13) & - & - & 2.97 & 10.37 \\
\hline o-methylstyrene (14) & - & - & 0.51 & 2.14 \\
\hline indan & - & - & - & 0.13 \\
\hline$m / p$-allyltoluene & - & - & 0.95 & 3.83 \\
\hline o-allyltoluene (4) & - & - & 0.21 & 0.40 \\
\hline $\mathrm{HA}$ & - & - & $e$ & - \\
\hline indene (8) & - & - & 0.34 & 1.64 \\
\hline 2-methylindan (7) & - & - & - & 0.22 \\
\hline o-methylbenzaldehyde & - & 0.33 & 0.39 & 0.21 \\
\hline$o-(1-$ propenyl)toluene & - & - & - & 0.15 \\
\hline $\mathrm{HB}-146\left[\mathrm{C}_{11} \mathrm{H}_{14}\right]$ & - & - & 0.16 & 0.43 \\
\hline $\mathrm{HC}-146\left[\mathrm{C}_{11} \mathrm{H}_{14}\right]$ & - & - & 0.16 & 0.22 \\
\hline o-(3-butenyl)toluene (9) & 100.0 & 64.20 & 41.73 & 15.87 \\
\hline
\end{tabular}

Table A-II continues on next page 
Table A-II. Continued

\begin{tabular}{|c|c|c|c|c|}
\hline \multirow[b]{2}{*}{ entry } & \multicolumn{4}{|c|}{ yleld, \% C } \\
\hline & $\mathrm{RT} d$ & $702^{\circ} \mathrm{C}$ & $808^{\circ} \mathrm{C}$ & $902{ }^{\circ} \mathrm{C}$ \\
\hline $\mathrm{HD}-146\left[\mathrm{C}_{11} \mathrm{H}_{14}\right]$ & & 0.32 & 0.25 & 0.12 \\
\hline 2-methyl-1H-indene & - & - & 0.23 & 0.10 \\
\hline TK-130 $\left[\mathrm{C}_{10} \mathrm{H}_{10}\right]$ & - & - & - & 0.14 \\
\hline 1,2-dihydronaphthalene (2) & - & - & 0.30 & 0.30 \\
\hline$T M$ & - & - & $e$ & $e$ \\
\hline naphthalene (5) & - & - & 0.45 & 1.38 \\
\hline $\mathrm{HE}-146\left[\mathrm{C}_{11} \mathrm{I}_{14}\right]$ & - & - & 0.20 & 0.12 \\
\hline $\mathrm{HF}-156\left[\mathrm{C}_{12} \mathrm{H}_{12}\right]$ & - & - & - & 0.20 \\
\hline 2-methylnaphthalene & - & - & - & 0.10 \\
\hline 1-methylnaphthalene & - & - & - & 0.18 \\
\hline $\mathrm{HG}-182\left[\mathrm{C}_{14} \mathrm{H}_{14}\right]$ & - & - & - & 0.46 \\
\hline $\mathrm{HH}-182\left[\mathrm{C}_{14} \mathrm{H}_{14}\right]$ & - & - & - & 0.47 \\
\hline $\mathrm{HI}-196\left[\mathrm{C}_{15} \mathrm{H}_{16}\right]$ & - & - & - & 0.29 \\
\hline $\mathrm{HJ}-196\left[\mathrm{C}_{15} \mathrm{H}_{16}\right]$ & - & - & 2.15 & 4.24 \\
\hline $\mathrm{HK}-210\left[\mathrm{C}_{16} \mathrm{H}_{18}\right]$ & - & - & 0.37 & 0.49 \\
\hline 1,2-di(o-tolyl)ethane (11) & - & 34.38 & 39.36 & 7.59 \\
\hline $\mathrm{HL}-178\left[\mathrm{C}_{14} \mathrm{H}_{10}\right]$ & - & - & 0.63 & 1.46 \\
\hline $\mathrm{HM}-208\left[\mathrm{C}_{16} \mathrm{H}_{16}\right]$ & - & - & - & 0.46 \\
\hline $\mathrm{HN}-192\left[\mathrm{C}_{15} \mathrm{H}_{12}\right]$ & - & - & - & 0.47 \\
\hline recovery $f$ & 102.4 & 97.77 & 88.72 & 110.0 \\
\hline conversion $g$ & $d$ & 35.80 & 58.27 & 84.13 \\
\hline
\end{tabular}

Table A-II footnote on next page 
Table A-II. Footnote

$a_{\text {FVP }}$ conditions: system pressure $=0.010$ torr, sample temperature $=0{ }^{\circ} \mathrm{C}$. $b$ Amounts determined by GC with a known quantity of biphenyl added as standard. Data represent the average of triplicate runs. Products identified by comparison with authentic samples or those that could be identified by retention time and GCMS are indicated by name. Products that were identified by GCMS only are indicated by code: $\mathrm{XY}$ - $\mathrm{nnn}$, where ' $\mathrm{X}$ ' corresponds to the system studied $(\mathrm{H}=$ pyrolysis of $9, \mathrm{~T}=$ pyrolysis of 1 ), $Y$ to the individual unknown product ( $A, B, C$, etc.), and ' $n$ nn' to the nominal mass. $c$ See Table A-I, footnote $c{ }^{d}$ See Table A-I, footnote $d$. $e$ See Table A-I, footnote e. $f$ See Table A-I, footnote $f . g$ See Table A-I, footnote $g$. 
Table A-III. Products and recovered starting material, total recovery of material, and conversion from the FVP of 0 -(4-pentenyl)toluene $(10)$ at various oven temperatures $a, b$

\begin{tabular}{|c|c|c|c|c|}
\hline \multirow[b]{2}{*}{ entry } & \multicolumn{4}{|c|}{ yield, $\% c$} \\
\hline & $\mathrm{RT} d$ & $613^{\circ} \mathrm{C}$ & $707^{\circ} \mathrm{C}$ & $800^{\circ} \mathrm{C}$ \\
\hline toluene & - & - & 0.26 & 3.24 \\
\hline ethylbenzene & - & - & - & 1.32 \\
\hline o-xylene (12) & - & - & 1.00 & 5.65 \\
\hline styrene (6) & - & - & - & 2.54 \\
\hline benzocyclobutene (3) & - & - & 0.92 & 3.24 \\
\hline o-ethyltoluene (13) & - & & 0.88 & 3.15 \\
\hline o-methylstyrene (14) & - & 1.52 & 30.62 & 59.78 \\
\hline benzaldehyde & - & - & 0.21 & 1.33 \\
\hline indan & - & - & - & 1.07 \\
\hline$m / p$-allyltoluene & - & 0.31 & 0.26 & 0.51 \\
\hline o-allyltoluene (4) & - & - & 0.20 & - \\
\hline indene (8) & - & - & 0.34 & 2.29 \\
\hline o-methylbenzaldehyde & - & - & 1.67 & 2.56 \\
\hline PA & - & - & $e$ & - \\
\hline PB-146 $\left[\mathrm{C}_{11} \mathrm{H}_{14}\right]$ & - & - & 0.82 & 0.98 \\
\hline naphthalene (5) & - & - & 0.11 & 0.52 \\
\hline $\mathrm{PC}$ & $e$ & $e$ & $e$ & - \\
\hline PD & - & - & $e$ & - \\
\hline 2-(4-pentenyl)toluene (10) & 92.42 & 90.40 & 52.92 & 2.97 \\
\hline $\mathrm{PE}-160\left[\mathrm{C}_{12} \mathrm{H}_{16}\right]$ & - & - & 0.58 & 0.52 \\
\hline PF & - & - & $e$ & - \\
\hline
\end{tabular}

Table A.III continues on next page 
Table A-III. Continued

\begin{tabular}{lcccc}
\hline & \multicolumn{4}{c}{ yield, \% $\mathrm{c}$} \\
\cline { 2 - 5 } entry & $\mathrm{RT} d$ & $613^{\circ} \mathrm{C}$ & $707^{\circ} \mathrm{C}$ & $800{ }^{\circ} \mathrm{C}$ \\
\hline PG-160 $\left[\mathrm{C}_{12} \mathrm{H}_{16}\right]$ & - & - & 0.97 & 1.10 \\
$2,2^{\prime}$-dimethylbiphenyl & 7.58 & 7.77 & 8.23 & 7.22 \\
& & & & \\
recovery $e$ & 97.85 & 96.20 & 86.59 & 70.36 \\
conversion $f$ & $d$ & 9.60 & 47.08 & 97.03 \\
\hline
\end{tabular}

$a$ See Table A-II, footnote $a .^{b}$ Amounts determined by GC with a known quantity of biphenyl added as standard. Data represent the average of triplicate runs. Products identified by comparison with authentic samples or those that could be identified by retention time and GCMS are indicated by name. Products that were identified by GCMS only are indicated by code: $X Y-n n n$, where ' $X$ ' corresponds to the system studied $(P=$ pyrolysis of 10$), Y$ to the individual unknown product $(A, B, C$, etc.), and 'nnn' to the nominal mass. $c$ See Table A-I, footnote $c$. $d$ See Table A-I, footnote $d$. $e$ Unidentified product which constitutes $\leq 0.35 \%$ total area by GC. $f$ See Table A-I, footnote $f . g$ See Table A-I, footnote $g$. 


\section{GENERAL SUMMARY}

In the gas-phase thermal decomposition studies of tetralin (1) found in paper 1. the relative amounts of dehydrogenation products, 1,2-dihydronaphthalene (2) and naphthalene (6), to ethylene loss products, benzocyclobutene (3) and styrene (6), vary with the conditions of the experiment. The multiphoton dissociation (MPD) of 1 produces mostly ethylene loss while the pulsed and continuous wave (cw) laser-sensitized decomposition of 1 produces mostly dehydrogenation. The relative amounts of dehydrogenation to ethylene loss in the flash vacuum pyrolysis (FVP) of 1 are dependent on the system pressure and the sample temperature. In the FVP of 1 at $10^{-5}$ torr, the ratio of dehydrogenation to ethylene loss remains ca. $1(0.90-1.03)$ from 850 to $950{ }^{\circ} \mathrm{C}$ and finally drops to 0.73 at $1000^{\circ} \mathrm{C}$. On the other hand, when 1 is pyrolyzed at 0.10 torr a distinct drop in the dehydrogenation to ethylene loss ratio, from 2.70 to 0.72 , with increasing pyrolysis temperature is observed. High sample temperature increases the proportion of dehydrogenation. When 1 is pyrolyzed under flow conditions, where sample molecules are diluted with a large excess of Ar, ethylene loss exceeds dehydrogenation by a ratio of between 3 and 5 to 1 over a wide temperature and conversion range. These flow experiments show that the lowest energy unimolecular gas-phase decomposition channel for 1 is ethylene loss. A bimolecular dehydrogenation reaction, possibly a hydrogen atom chain, is responsible for greater amounts of hydrogen-loss products observed under some conditions in the decomposition of 1 . In none of our pyrolysis experiments, whether laser-induced or under standard pyrolysis conditions, did we find any evidence of heterogeneous catalytic reactions on surfaces. We can conclude that MPD favors the lowest energy unimolecular 
decomposition channel while laser-sensitized pyrolysis (cw or pulsed) can lead to homogenous bimolecular reactions as well.

We have observed the faclle transformation of o-allyltoluene (4) to 2-methylindan (7), which we propose occurs through an intramolecular hydrogen atom transfer from the benzylic methyl group to the double bond of 4 . Loss of a methyl from 7 leads to the formation of indene (8). We have identified the transformation 4 to 7 to 8 as the major source of 8 in the gas-phase thermal decomposition of 1.

Paper 2 shows that the FVP of 3-benzocycloheptenone (10') leads to the formation of tetralin (1), 1,2-dihydronaphthalene (2), naphthalene (5), indene (8), 1-methylnaphthalene (12'), 2-methylnaphthalene (13'), and several other minor products. The results from the flow pyrolysis of $10^{\prime}$ are similar. An unusual aspect of the pyrolysis of $10^{\prime}$ is the formation of $12^{\prime}$ and 13'. products formed by a net loss of water from ketone 10'. The photolysis of $10^{\prime}$ at $25^{\circ} \mathrm{C}$ in solution gives mostly 1 and some $o$-allyltoluene (4). In contrast to the pyrolysis of $10^{\prime}$, FVP of 1,3,4,5-tetrahydro-2-benzothiepin-2,2-d1oxdde (11') leads to the formation of large amounts of 1 and some 4 with only small amounts of other products. It is concluded that the 1,6-diradical formed by cleavage of the benzylic bond of 1 is produced in the pyrolysis and photolysis of 10', and the pyrolysis of 11'. This diradical gives rise to 1 and 4 in a ratio between 3 and 8 to 1 over a temperature range of 25 to $950^{\circ} \mathrm{C}$. The pyrolysis of $10^{\prime}$ involves other major reactions. Mechanisms for these reactions are proposed.

In paper 3, the FVP of bis(o-allylbenzyl) oxalate $\left(9^{\prime \prime}\right)$ at $700-900{ }^{\circ} \mathrm{C}$ gtves as the major product 1,2-dihydronaphthalene (2). Several other minor products including naphthalene (3"), Indene (6"), 3-methyl-1H-indene (10"), and 2-methyl-1H-indene (11") are also produced. At lower temperatures the dimer of 0 -allylbenzyl radical (7"). 1,2-di(2-allylphenyl)ethane (14"), is produced in low yield. These results are consistent 
with the production of radical 7" as an intermediate in the FVP of 9". Formation of the major product 2 is readily explained by closure of 7" to 2-tetryl radical (16") followed by loss of a $\beta$ hydrogen atom.

Paper 4 describes the FVP of 1,4-diphenylbutane $\left(9^{\prime \prime \prime}\right)(70 C \quad l \quad$.Jrr) produces 1,2-diphenylethane (10'") in high yleld. At higher temper; ..co, ca. 10\% toluene (11"') and small amounts (<2.5\%) of indan (12"'), styrene (13"'), ethylbenzenc (14"'), allylbenzene (15'"), butylbenzene (19"'), and diphenylmethane (20"') are also produced. Formation of the benzyl radical coupling product 10"' as the major product is consistent with initial cleavage of the benzylic carbon-carbon bond of $9^{\prime \prime}$ to form a benzyl radical and 3-phenylpropyl radical (8"'), followed by the loss of ethylene from $8^{\prime \prime \prime}$ to produce another benzyl radical. Formation of 8 "'. is supported by the detection of Indan (12'") as a minor product. The results show that the major reaction of $\boldsymbol{8}^{\prime \prime}$ in the gas-phase is $\beta$ carbon-carbon bond cleavage to produce ethylene and benzyl radical; the loss of a $\beta$ hydrogen to form allylt $\quad 16^{\prime \prime \prime)}$ and cyclization to indan (12'") are minor reactions under these conditions. Formation of the minor products toluene (11'"), styrene (13"'), ethylbenzene (14"'), butylbenzene (19"'), and diphenylmethane (20'") at higher temperatures indicates that some induced decomposition of $9^{\prime \prime \prime}$ is occurring.

In paper 5 , the FVP of 0 -allyltoluene (4) at $700^{\circ} \mathrm{C}$ and $800^{\circ} \mathrm{C}$ gives as the major product 2-methylindan (7). At $900^{\circ} \mathrm{C}, 7$ is still produced but the major product is indene (8). It is proposed that 7 is produced by a two-step mechanism involving 1,5-diradical 15"'" formed by an intramolecular hydrogen atom transfer. Conversion of 7 to indene<smiles>C=CCc1ccccc1C</smiles>
4<smiles>CCCc1ccccc1CC</smiles>

$15^{\prime \prime \prime \prime}$

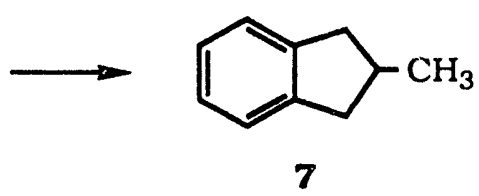


(8) at higher temperatures is explained by the loss of a methyl group from 7 to form the 2 -indanyl radical which would readily lose a $\beta$ hydrogen atom to give 8 . The calculated $\Delta H^{\circ}$ for this reaction is $45 \mathrm{kcal} \mathrm{mol}^{-1}$. We have also pyrolyzed o-(3-butenyl)toluene $(9 " \prime)$, which undergoes homolytic bond cleavage, and o-(4-pentenyl)toluene (10"'"), which forms 0 -methylstyrene (14'"') through a retro-ene reaction. From the $\Delta H^{\ddagger}$ of these reactions, we estimate the $\Delta H^{\ddagger}$ for the 4 to 7 conversion is $65 \mathrm{kcal} \mathrm{mol}^{-1}$.

In this dissertation, a clearer understanding of the high temperature gas-phase chemistry of tetralin has resulted from our decomposition studies of the simplest hydroaromatic compound and related model systems. We have demonstrated that the lowest energy unimolecular decomposition reaction of tetralin is ethylene loss and that a faclle bimolecular dehydrogenation reaction occurs under some conditions. We have found no evidence of heterogeneous surface reactions in the gas-phase decomposition of tetralin. The decomposition of model systems designed to probe the pathways involved in tetralin decomposition has resulted in a greater understanding of the mechanism of tetralin decomposition and has suggested avenues for further research. 


\section{ACKNOWLEDGMENTS}

I would like to thank Professor Walter S. Trahanovsky for his guidance during my graduate study at lowa State. I would also like to thank members of the Trahanovsky research group for their friendship and assistance.

Above all, I would like to thank my parents. Their love, support, patience and example have made all that I have achieved possible. 


\section{INTRODUCTION}

Our recent research efforts have been directed toward understanding the gas-phase thermal chemistry of tetralin (1). In previous work, 1 has been used as a hydrogen-donor solvent for coal liquefaction processes ${ }^{1}$ and, as the simplest hydroaromatic compound, has been studied as a model of this important structural feature of coal. ${ }^{2}$ The gas-phase chemistry of 1 at elevated temperatures has been examined under static, flow, and vacuum pyrolysis conditions, 3,4 through sensitized laser-induced thermal decomposition, 5.6 and in single-pulse shock tube experiments. ${ }^{7}$ The major products of tetralin thermal decomposition (Scheme I) include primary products 1.2-dihydronaphthalene (2), benzocyclobutene (3), and o-allyltoluene (4). Secondary products. naphthalene (5) from 2 , styrene (6) from 3,2 -methylindan $(7)^{8}$ from 4 , and indene (8) primarlly from 7 , have been identified along with various minor products.

Analysis of the complex tetralin product mixtures is simplified by treating the "hydrogen-loss" or dehydrogenation products 1,2-dihydronaphthalene (2) and naphtha-

\section{Scheme I}

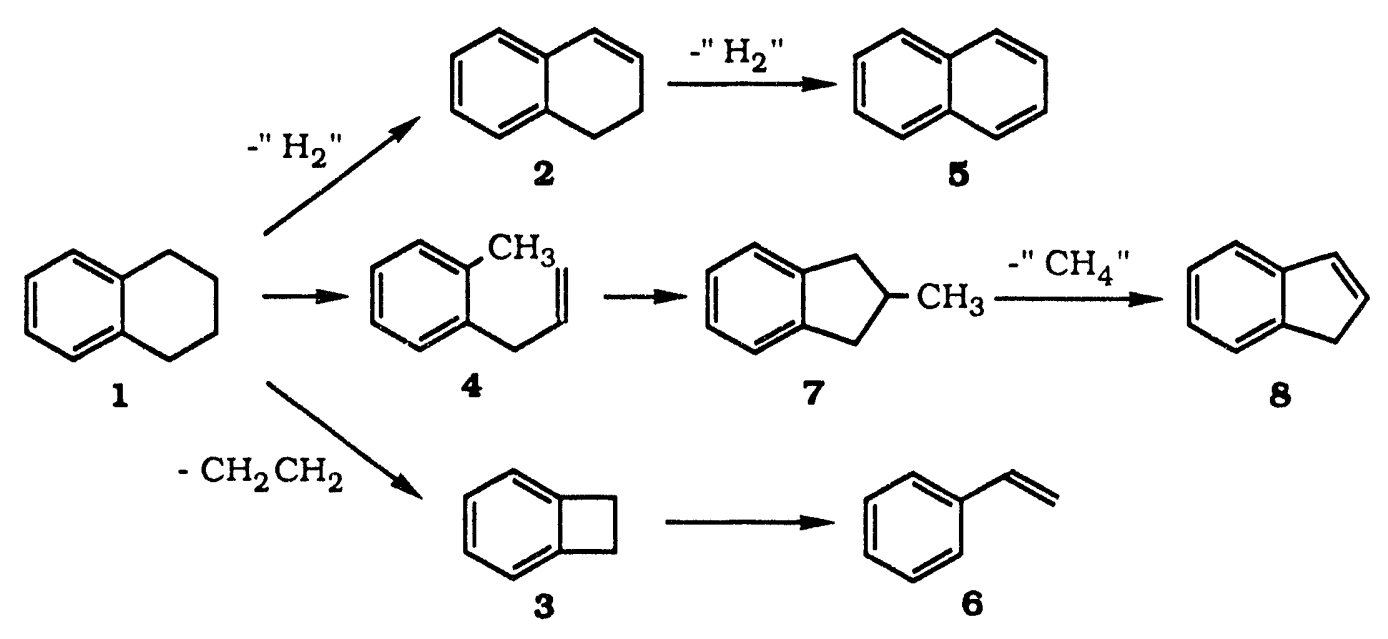


lene (5) together. Similarly, benzocyclobutene (3) and styrene (6) are alsu considered as a group and referred to as "ethylene-loss" products. The ratio of dehydrogenation to ethylene loss will be used to evaluate tetralin pyrolysis mixtures.

Gas-phase pyrolysis 4 of 1 has been reported to give primardly dehydrogenation. while laser-induced decomposition ${ }^{5}$ and single-pulse shock tube studies ${ }^{7}$ gave primarily ethylene loss. It has been suggested that surface catalytic effects have influenced the pyrolysis results. $5 \mathrm{~b}$ In this paper, we report our reexamination of the thermal decomposition of 1 under both laser-induced and pyrolysis conditions.

In our experiments, the laser-sensitized decomposition of 1 produced primarily dehydrogenation. These results are at variance with those previously reported; 5 how. ever, our gas-phase pyrolysis results confirm that the lowest energy unimolecular decomposition reaction of 1 is ethylene loss. We show that the excess dehydrogenation observed is not the result of a surface catalytic effect. We believe a bimolecular reaction sequence produces excess dehydrogenation under some conditions. 
$r$
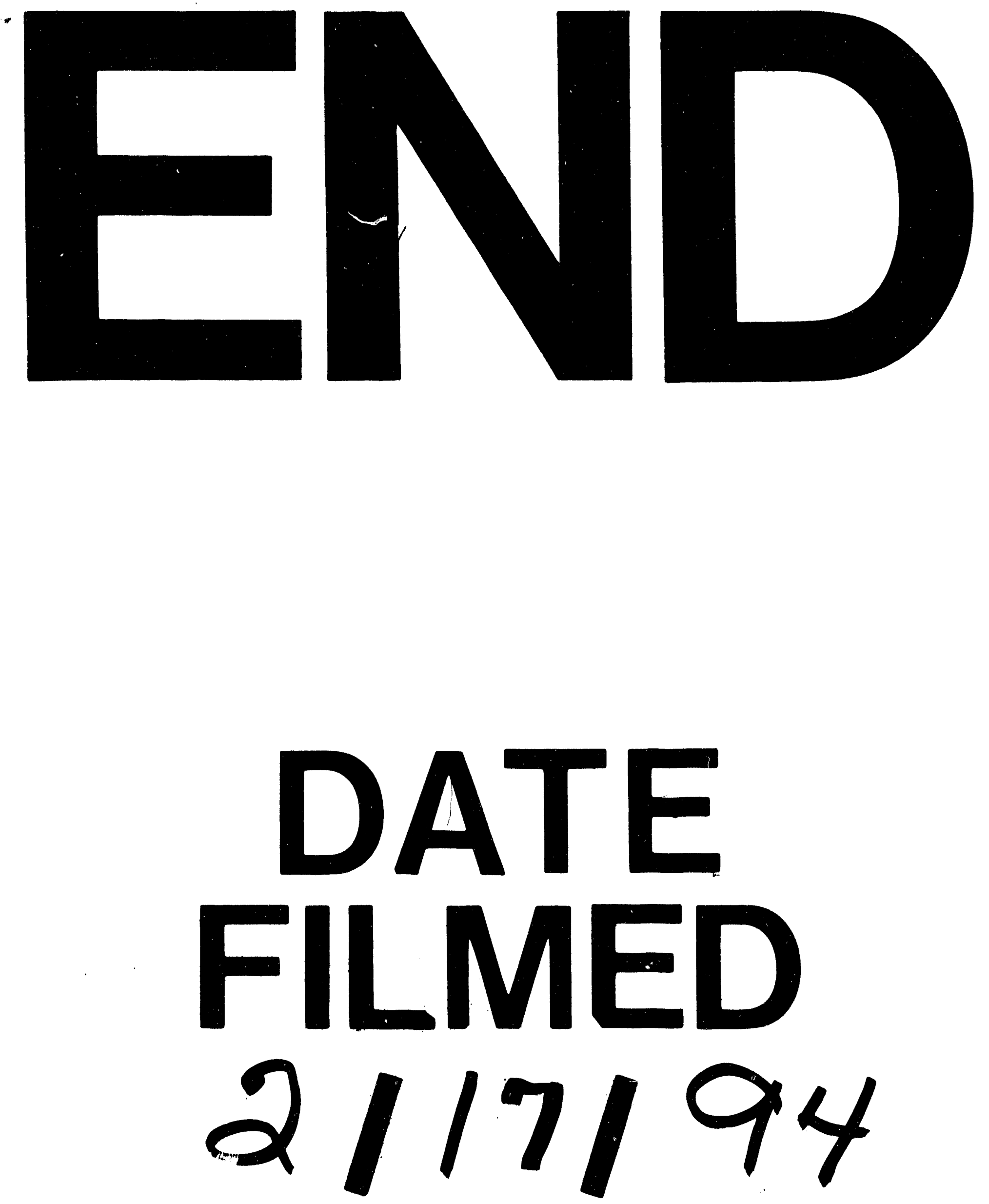
